\begin{tabular}{|c|c|c|c|c|}
\hline \multirow{3}{*}{$\begin{array}{l}\text { 2. ECN Category } \\
\text { (mark one) } \\
\text { Supplemental } \\
\text { Direct Revision } \\
\text { Change ECN } \\
\text { Temporary } \\
\text { Standby } \\
\text { Supersedure } \\
\text { Cancel/Void }\end{array}$} & \multirow{3}{*}{$\begin{array}{c}{[]} \\
{[\mathrm{x}]} \\
{[]} \\
{[]} \\
{[]} \\
{[]} \\
{[]}\end{array}$} & $\begin{array}{l}\text { 3. Originator's Name, Organization, MSIN, } \\
\text { and Telephone No. } \\
\text { R. D. Crowe / SNF-NS/R3-26 } \\
\text { 376-8028 }\end{array}$ & $\begin{array}{l}\text { 4. USQ Required? } \\
\text { XYes [x]+Nofirtol }\end{array}$ & $\begin{array}{l}\text { 5. Date } \\
\text { 7/177or }\end{array}$ \\
\hline & & $\begin{array}{l}\text { 6. Project Title/No./Work Order No. } \\
\text { Spent Nuclear Fuel Project }\end{array}$ & $\begin{array}{l}\text { 7. Bldg./Sys./Fac. No. } \\
\qquad-44 /\end{array}$ & $\begin{array}{l}\text { 8. Approval Designator } \\
\qquad S^{N}, Q\end{array}$ \\
\hline & & $\begin{array}{l}\text { 9. Document Numbers Changed by this ECN } \\
\text { (includes sheet no. and rev.) } \\
\text { HNF-SD-SNF-HIE-004, Rev. } 4\end{array}$ & $\begin{array}{l}\text { 10. Related ECN No(s). } \\
\text { N/A }\end{array}$ & 11. Related PO No. \\
\hline
\end{tabular}

\begin{tabular}{|c|c|c|c|}
\hline $\begin{array}{l}\text { 12a. Modification Work } \\
\text { [] Yes (fill out Blk. 12b) } \\
\text { [x] No (NA Blks. 12b, 12c, 12d) }\end{array}$ & $\begin{array}{l}\text { 12b. Work Package } \\
\text { No. } \\
\text { N/A }\end{array}$ & $\begin{array}{l}\text { 12c. Modification Work Complete } \\
\text { N/A } \\
\begin{array}{c}\text { Design Authority/Cog. Engineer } \\
\text { Signature \& Date }\end{array}\end{array}$ & $\begin{array}{l}\begin{array}{l}\text { 12d. Restored to Ori } \\
\text { Standby ECN only) } \\
\text { N/A } \\
\begin{array}{r}\text { Design Auth } \\
\text { Signz }\end{array}\end{array}\end{array}$ \\
\hline \multicolumn{4}{|c|}{ 13b. Design Baseline Document? [] Yes $[\mathrm{x}]$ No } \\
\hline \multicolumn{4}{|c|}{$\begin{array}{l}\text { The changes to HNF-SD-SNF-HIE- } 004 \text { are used as input to the Cold Vacuum Drying Facility Final Safety At } \\
3553 \text {, Annex B, Revision } 1 \text {. The changes reflect evaluation of: }\end{array}$} \\
\hline \multicolumn{4}{|c|}{ 1) USQ-Like CVD-00-0207, change in facility from 4 process bays to 2} \\
\hline \multicolumn{2}{|c|}{ 2) use of spare bays for decontamination } & in activities as an interim location & isk/MCO storage \\
\hline & $202^{2}, \mathrm{MCO}$ lift d & Cask overpressure. & \\
\hline
\end{tabular}

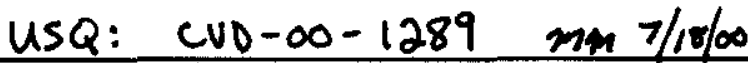

\begin{tabular}{llllllll}
\hline 14a. Justification (mark one) & & & & & & & \\
Criteria Change & {$[\mathrm{x}]$} & Design Improvement & {[]} & Environmental & {[]} & Facility Deactivation & {[]} \\
As-Found & {[]} & Facilitate Const & {[]} & Const. Error/Omission & {[]} & Design Error/Omission & {[]}
\end{tabular}

14b. Justification Details

See block 13a.

15. Distribution (include name, MSIN, and no. of copies)
AUG

DATE

Distribution sheet attached.

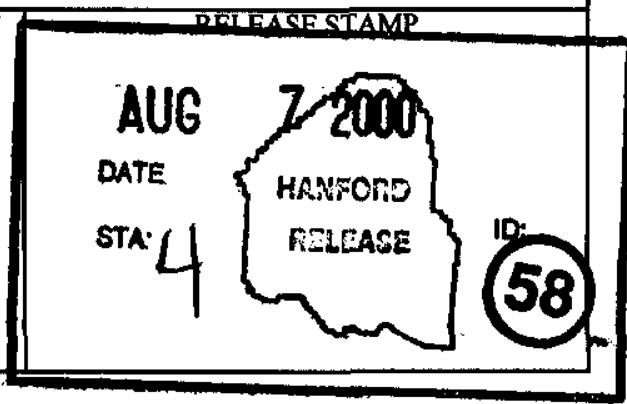

A-7900-013-2 (05/96) GEF095 


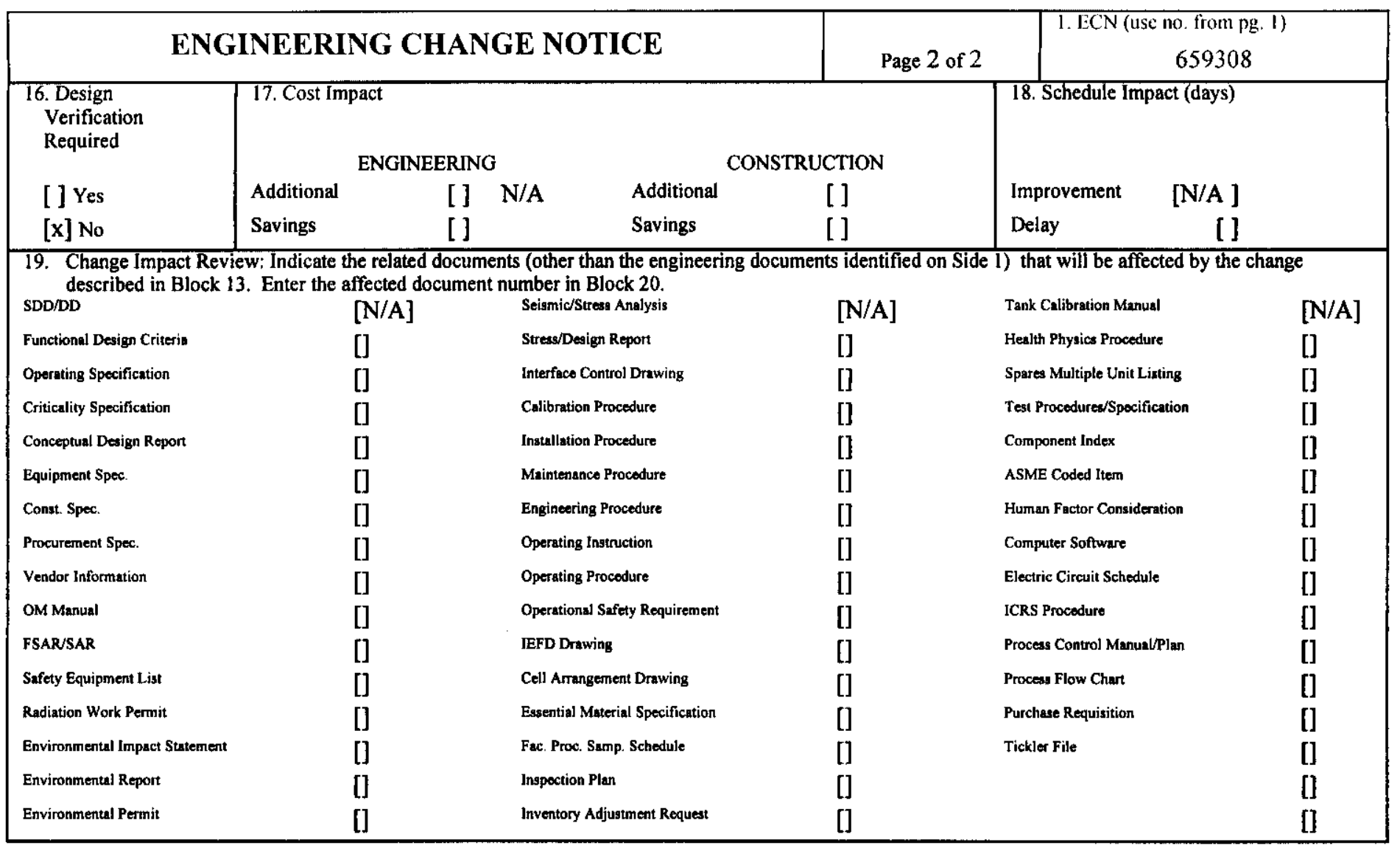

20. Other Affected Documents: (NOTE: Documents listed below will not be revised by this ECN.) Signatures below indicate that the signing organization has been notified of other affected documents listed below.

Document Number/Revision

Document Number/Revision

N/A
Document Number Revision
21. Approvals Signature

Date

Cog. Eng. R. D. Crowe

Cog. Mgr. c. T. Miller by

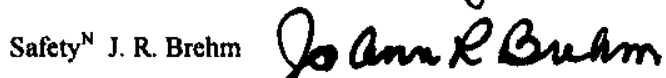

QA R. K. Ramsgate

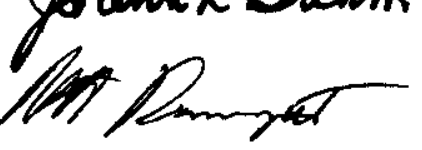

Signature

Date
DEPARTMENT OF ENERGY

Signature or a Control Number that tracks the Approval Signature

ADDITIONAL 
Revision 5

\section{Cold Vacuum Drying Facility Final Hazard Analysis Report}

Abstract: This report describes the methodology used in conducting the Cold Vacuum Drying Facility (CVDF) Hazard Analysis to support the CVDF Final Safety Analysis Report and documents the results. The hazard analysis was performed in accordance with DOE-STD-3009-94, "Preparation Guide for U.S. Department of Energy Nonreactor Nuclear Facility Safety Analysis Reports," and implements the requirements of DOE Order 5480.23, "Nuclear Safety Analysis Reports."

Key Words: hazard, analysis 


\section{Cold Vacuum Drying Facility Final Hazard Analysis Report}

Prepared for the U.S. Department of Energy

Assistant Secretary for Environmental Management

Project Hanford Management Contractor for the

U.S. Department of Energy under Contract DE-AC06-96RL13200

Fluor Hanford

P.O. Box 1000

Richland, Washington 
HNF-SD-SNF-HIE-004

Revision 5

ECN 659308

Total Pages 92

\section{Cold Vacuum Drying Facility Final Hazard Analysis Report}

Division: SNF

R. D. Crowe

XWest Group, Inc.

Date Published

July 2000

Prepared for the U.S. Department of Energy

Assistant Secretary for Environmental Management

Project Hanford Management Contractor for the

U.S. Department of Energy under Contract DE-AC06-96RL13200

Fluor Hanford

P.O. Box 1000

Richland, Washington
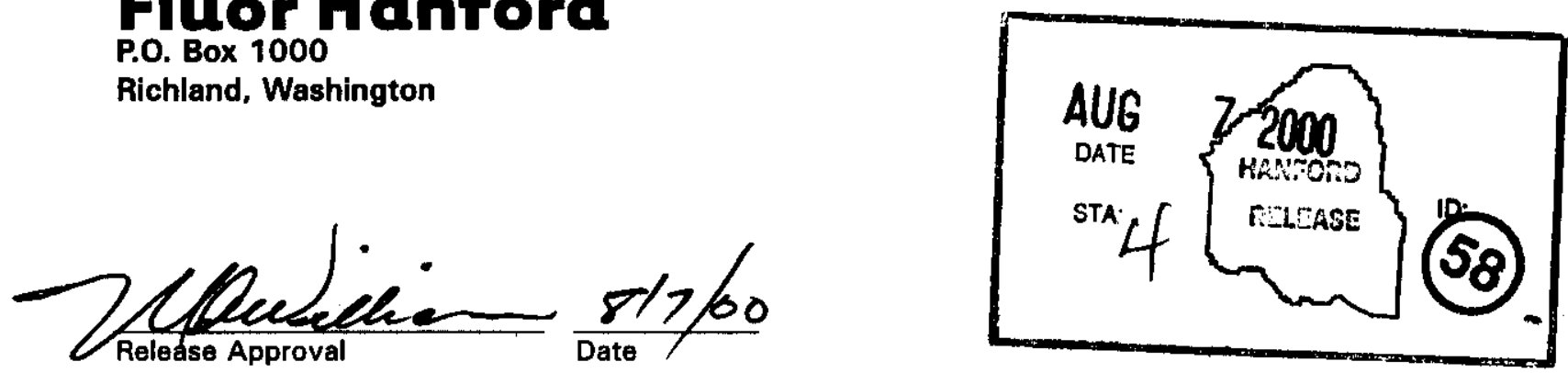


\section{RECORD OF REVISION}

(1) Document Number

HNF-SD-SNF-HIE-004,

Rev. 5

(2) Title

Cold Vacuum Drying Facility Final Hazard Analysis Report

\begin{tabular}{|c|c|c|c|}
\hline \multicolumn{4}{|c|}{ CHANGE CONTROL RECORD } \\
\hline \multirow[t]{2}{*}{ (3) Revision } & \multirow[t]{2}{*}{ (4) Description of Change - Replace, Add, and Delete Pages } & \multicolumn{2}{|c|}{ Authorized for Release } \\
\hline & & (5) Cog. Engr. & (6) Cog. Mgr. \\
\hline & (7) & & \\
\hline 0 & EDT: 607696 & & \\
\hline 1 & $\begin{array}{l}\text { ECN: } 630494 \\
\text { This hazard analysis has been updated to reflect continuing design } \\
\text { progress to date. Revision } 1 \text { of this document reflects design } \\
\text { information as provided in the Cold Vacuum Drying Facility } \\
\text { Safety Analysis Report, Phase II, HNF-SD-SNF-SAR-002, } \\
\text { Revision } 3 .\end{array}$ & & \\
\hline 2 & $\begin{array}{l}\text { ECN: } 637182 \\
\text { This revision of the hazard analysis has been updated to reflect the } \\
\text { elimination of the MCO relief valve during processing. This also } \\
\text { reflects information as provided in the Cold Vacuum Drying } \\
\text { Facility Safety Analysis Report, Phase II, HNF-SD-SNF-SAR-002, } \\
\text { Revision } 4 .\end{array}$ & & \\
\hline $2 \mathrm{~A}$ & $\begin{array}{l}\text { ECN: } 637191 \\
\text { This revision reflects the changes in the Cold Vacuum Drying } \\
\text { Facility Safety Analysis Report, Phase } I I, H N F-S D-S N F-S A R-002, \\
\text { Revision } 4 A .\end{array}$ & & \\
\hline 3 & $\begin{array}{l}\text { ECN: } 647505 \\
\text { This revision reflects the changes in the Cold Vacuum Drying } \\
\text { Facility Final Safety Analysis Report, HNF-3553 Annex B, } \\
\text { Revision } 0 .\end{array}$ & & \\
\hline 4 & $\begin{array}{l}\text { ECN: } 656326 \\
\text { This revision is used as input in the Annex B volume of } H N F-3553 \text {. }\end{array}$ & & \\
\hline RS & 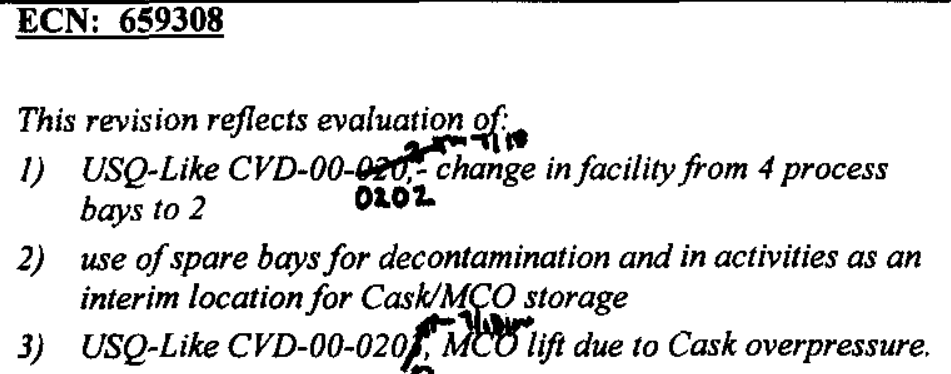 & R. Crowe & $\begin{array}{l}\text { C. T. Miller } \\
\text { Con }\end{array}$ \\
\hline
\end{tabular}


TRADEMARK DISCLAIMER

Reference herein to any specific commercial product, process, or service by trade name, trademark, manufacturer, or otherwise, does not necessarily constitute or imply its endorsement, recommendation, or favoring by the United States Government or any agency thereof or its contractors or subcontractors.

This report has been reproduced from the best available copy. Available in paper copy and microfiche.

Available electronically at http://www.doe.gov/bridge. Available for a processing fee to the U.S. Department of Energy and its contractors, in paper, from:

U.S. Department of Energy

Office of Scientific and Technical Information

P.O. Box 62

Oak Ridge, TN 37831-0062

phone: 865-576-8401

fax: 865-576-5728

email: reports@adonis.osti.gov(423) 576-8401 


\section{COLD VACUUM DRYING FACILITY}

HAZARD ANALYSIS REPORT

HNF-SD-SNF-HIE-004

Revision 5

July 2000 
HNF-SD-SNF-HIE-004 REV 5

This page intentionally left blank. 


\section{HNF-SD-SNF-HIE-004 REV 5}

\section{CONTENTS}

1.0 INTRODUCTION 1

2.0 SCOPE OF THE HAZARD ANALYSIS $\ldots \ldots \ldots \ldots \ldots \ldots \ldots \ldots \ldots \ldots \ldots \ldots$

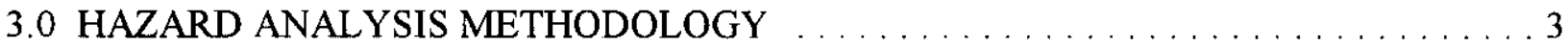

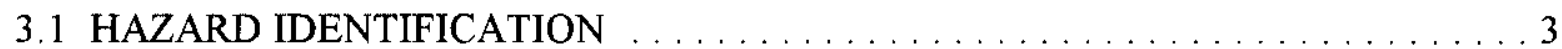

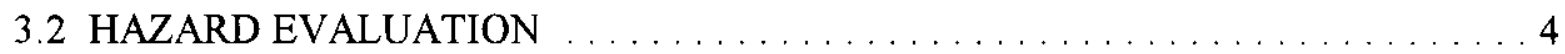

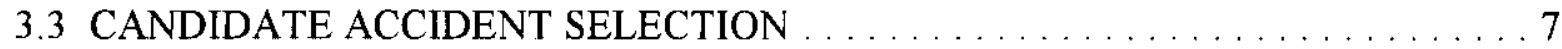

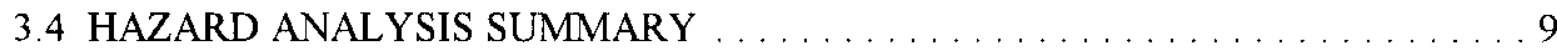

4.0 REFERENCES . . . . . . . . . . . . . . . . . . . . . . . . 9

\section{ATTACHMENTS}

1 COLD VACUUM DRYING FACILITY HAZARD ANALYSIS

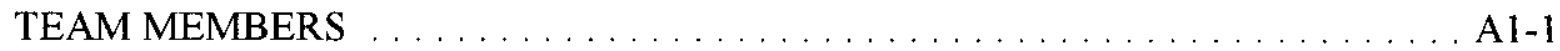

2 COLD VACUUM DRYING FACILITY HAZARD ANALYSIS $\ldots \ldots \ldots \ldots \ldots$ A2-1

3 RELEASE CHARACTERISTICS FOR HAZARDOUS CONDITIONS ASSOCIATED WITH OFFSITE (SITE BOUNDARY) AND ONSITE (COLLOCATED WORKER) RECEPTORS

4 BINNED LISTING OF CANDIDATE ACCIDENTS SORTED BY RISK RANKING . . . . . . . . . . . . . . . . . . . . . . . . . A4-1 


\section{HNF-SD-SNF-HIE-004 REV 5}

\section{LIST OF FIGURES}

1 Main Areas of the Cold Vacuum Drying Facility

\section{LIST OF TABLES}

1 Cold Vacuum Drying Facility Material at Risk (Type, Form, and Quantity) . . . . . . . 11

2 Hazardous Material/Energy Source Checklist: Example . . . . . . . . . . . . 13

3 Hazardous Material/Energy Source Checklist: Administrative Area (AA) . . . . . . . . 14

4 Hazardous Material/Energy Source Checklist: Transfer Corridor and

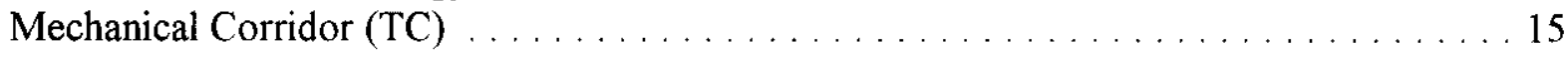

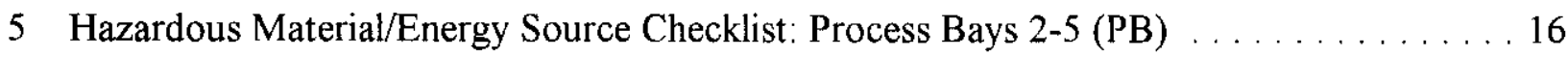

6 Hazardous Material/Energy Source Checklist: Process Bay 1 (Spare Bay) (SB) . . . . . . 17

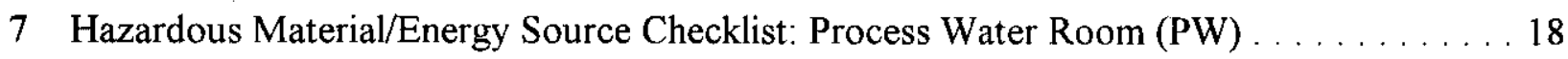

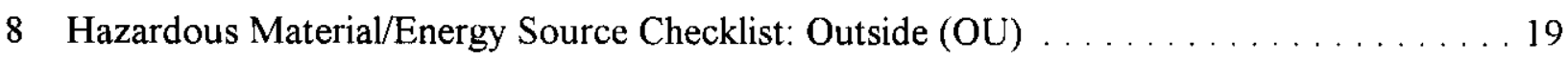

9 Standard Industrial Hazards: Administrative Area . . . . . . . . . . . . . . . 20

10 Standard Industrial Hazards: Transfer Corridor and Mechanical Corridor. . . . . . . . . . 22

11 Standard Industrial Hazards: Process Bays 2 through $5 \ldots \ldots \ldots \ldots \ldots \ldots$

12 Standard Industrial Hazards: Process Bay I (Spare Bay) . . . . . . . . . . . . . 26

13 Standard Industrial Hazards: Process Water Room. . . . . . . . . . . . . . . 28

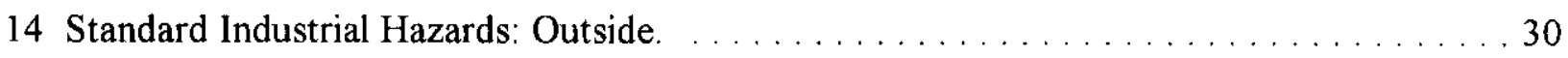


HNF-SD-SNF-HIE-004 REV 5

\section{LIST OF TERMS}

CVDF Cold Vacuum Drying Facility

DOE U.S. Department of Energy

FSAR final safety analysis report

MCO multi-canister overpack 


\section{HNF-SD-SNF-HIE-004 REV 5}

This page intentionally left blank. 


\section{COLD VACUUM DRYING FACILITY HAZARD ANALYSIS REPORT}

\subsection{INTRODUCTION}

This report describes the methodology used in conducting the Cold Vacuum Drying Facility (CVDF) hazard analysis to support the CVDF final safety analysis report (FSAR) and documents the results. The hazard analysis was performed in accordance with the U.S. Department of Energy (DOE) standard, DOE-STD-3009-94, Preparation Guide for U.S. Department of Energy Nonreactor Nuclear Facility Safety Analysis Reports, and implements the requirements of DOE Order 5480.23, Nuclear Safety Analysis Reports.

The hazard analysis process identified hazardous conditions and material at risk, determined causes for potential accidents, identified preventive and mitigative features, and qualitatively estimated the frequencies and consequences of specific occurrences. The hazard analysis was performed by a team of cognizant CVDF operations and design personnel, safety analysts familiar with the CVDF, and technical experts in specialty areas. Attachment A lists the members of the hazard analysis team and describes the background and experience of each.

The material included in this report documents the final state of a nearly two-year-long process involving formal facilitated group sessions and independent hazard and accident analysis work. The hazard analysis process led to the selection of candidate accidents for further quantitative analysis. New information relative to the hazards, discovered during the accident analysis, was incorporated into the hazard analysis data in order to compile a complete profile of facility hazards. Through this process, the results of the hazard and accident analyses led directly to the identification of safety structures, systems, and components; technical safety requirements; and other controls required to protect the public, workers, and environment.

\subsection{SCOPE OF THE HAZARD ANALYSIS}

The hazard analysis documented in this report, conducted to support the CVDF FSAR, covered normal, intended, CVDF operations to remove free water from the multi-canister overpacks (MCOs) containing spent nuclear fuel. The hazard analysis process, described in Chapter 3.0, examined:

- Routine activities to maintain the facility and to prepare for processing operations

- Receiving the trailer containing the cask-MCO, moving it into one of the facility's process bays, positioning and securing the trailer, and finalizing bay preparations for processing (processing operations are not planned in the spare bays) 
- Operations involved with venting the cask-MCO, removing the cask lid, preparing the $\mathrm{MCO}$ for processing, installing process equipment, and establishing process connections to the MCO

- Process hood/seal ring

$\rightarrow$ MCO process port connectors

- Tempered water system

- Verification and testing of equipment and connections prior to processing

- Monitoring and controlling process operations utilizing the monitoring and control system and the safety-class instrumentation and control system during the following processing modes

- Heatup Mode

- Drain Mode

- Purge/Flush Mode

- Drying Mode

- Proof Mode

- Pressure Test Mode

- Establishing MCO conditions for shipping, MCO port valve leak-testing, removing the process connections, reinstalling the process port covers, draining and drying the cask, and reinstalling the cask lid

- Preparing the trailer and bay for shipping, connecting the trailer to the transporter, and releasing the cask-MCO for shipment to the Canister Storage Building.

The following key sources of information were used to evaluate the hazards:

- HNF-3553, Spent Nuclear Fuel Project Final Safety Analysis Report, Annex B, "Cold Vacuum Drying Facility Final Safety Analysis Report"

- Chapters B2.0 and B4.0 for facility design and operations information

- Chapter B3.0 for the facility radioactive materials inventory

- Chapter B6.0 for evaluating the potential for hazards from nuclear criticality

- SNF-4268, Fire Hazard Analysis for the Cold Vacuum Drying Facility

- HNF-SD-TP-SARP-017, Safety Analysis Report for Packaging, (Insite, Multi-Canister ()verpack (ask, for coverage of accidents involving the transporter and transportation cask and for definition of assumptions inherent in defining the transportation window

- HNF-SD-SNF-SARR-005, Multi-( anister ()verpack lopical Report, for criteria and assumptions related to the $\mathrm{MCO}$ design 
- The latest available process information as presented in SNF-2356, Spent Nuclear Fuel Project Cold Vacuum Drying Facility (Operations Mamual

- Representatives from the design authority and from facility operations for details of design, operating modes, and procedures.

\subsection{HAZARD ANALYSIS METHODOLOGY}

This section presents the methodology used to perform the CVDF hazard analysis for normal operations. The hazard identification process systematically and comprehensively identified hazards that can contribute to the uncontrolled release of radioactive or hazardous materials or that can threaten the safety of facility workers. In addition to DOE Order 5480.23 and DOE-STD-3009-94, guidance provided in HNF-PRO-704, Hazard and Accident Analysis Process, and (Juidelines for Hazard Evaluation Procedures (AlChE 1985), was used to develop the hazard analysis process. Specifically, the analysis followed the American Institute of Chemical Engineers preliminary hazard analysis method, and included elements of the process/systems checklists and "what-if" analysis methods.

\subsection{HAZARD IDENTIFICATION}

The hazard analysis included identification of the hazards associated with CVDF design and operations based on descriptions provided in Chapters B2.0 and B4.0 of the CVDF FSAR (HNF-3553, Annex B) on an operational flow diagram, an operating sequence contained in the operations manual, and the other referenced material (see Section 4.0). The hazard analysis team included design authorities, operations personnel and hazard and accident analysts. The team met in facilitated sessions and communicated informally throughout the process. The team defined hazards as radioactive or hazardous materials (material at risk), system or process characteristics, or energy sources that represent a potential for an accident that could have an adverse effect on facility workers, the CVDF, the environment, or the public. Table 1 summarizes the material at risk for the CVDF in terms of type, form, and quantity.

A standardized checklist, Table 2, was used to identify potentially hazardous materials and energy sources present in each of the following six facility areas:

- Administrative area (AA)

- Transfer corridor and mechanical corridor (TC)

- Process bays 4 and 5 (PB)

- Spare bays 1, 2, and $3(\mathrm{SB})$

- Process water room (PW)

- Outside (OU).

Figure 1 provides a simplified drawing of the CVDF. 
Tables 3 through 8 show the hazard identification results for each area. Each identified hazard was assigned a unique designator to allow for tracking. The hazard identification checklists were developed by a subgroup of the hazard analysis team and reviewed and accepted by the entire team.

\subsection{HAZARD EVALUATION}

The hazard evaluation was a structured and systematic examination of the CVDF and its operations using standard industry (American Institute of Chemical Engineers) hazard evaluation techniques. The first step in the hazard evaluation, once the hazards had been identified, was to screen the potentially hazardous materials and energy sources for those that presented only standard industrial hazards. These hazards are defined in DOE-STD-3009-94 as those that "are routinely encountered in general industry and construction, and for which national consensus codes and/or standards (e.g., Occupational Safety and Health Administration, transportation safety) exist to guide safe design and operation without the need for special analysis to define safe design and/or operational parameters." Tables 9 through 14 list, by facility area, the standard industrial hazards that do not contribute to the uncontrolled release of radioactive or hazardous material. The standard industrial hazards listed are controlled through the implementation of institutional safety programs as described in the programmatic sections of the CVDF FSAR (HNF-3553, Annex B). The hazard analysis team agreed by consensus to the results of the screening for standard industrial hazard items.

Next, the team met in facilitated sessions to characterize each hazard. Hazard analysis worksheets were designed to capture the required information. Each hazard was assigned a unique identifier for tracking. Using the worksheets and the hazard summary as a guide, each hazardous condition was assessed to identify potential accidents, causes, frequencies, and consequences, and to determine a qualitative likelihood of occurrence of the initiating event and the resulting consequence. The assessment of likelihood and consequence for each hazardous condition was a collective, qualitative judgment made by the hazard analysis team. The assessment estimated the likelihoods and consequences of each hazardous condition scenario in two cases. The first case considered designed passive features only. The second case considered designed passive features as well as credited active features and administrative features.

The completed hazard analysis worksheets, included in this report in Attachment 2 as Table A2-1, show the results of the hazard evaluation as compiled by the hazard analysis team. The evaluation results are based on the hazard identification results, material-at-risk summaries, reviews of the systems designs and planned operations, existing safety documentation, and the experience of hazard analysis team members. Each column of the hazard analysis tables is explained below to aid in understanding the information contained therein.

Location/checklist entry. This column contains each hazard's unique identifier, which indicates the facility area, the hazard checklist category, and the specific hazard. For example, a designator of TV-F-01 would represent the truck vestibule (TV), a linear 
kinetic hazard $(\mathrm{F})$ from a car, truck, or bus $(01)$. If a single hazard could result in more than one consequence, a lowercase letter is appended to the identifier (e.g., TV-F-01a, TV-F-0 1b).

Hazard energy source/material. This column further defines the specific hazard under consideration (e.g., a moving transporter).

Hazardous condition. This column describes the hazardous condition that the energy source or material represents (e.g., transporter collision).

Cause. This column identifies initiators of the potential accident (e.g., transporter collision with facility structure [the potential accident] could be caused by human error on the driver's part, by mechanical failure of the vehicle, or by misplaced equipment). Typical potential causes include equipment failures, operational errors, abnormal operating conditions, poor operating practices, and environmental conditions. The causes of a potential accident are identified to support a qualitative frequency evaluation.

Potential accident. This column identifies potential accidents that could result from the identified hazardous conditions (e.g., transporter collision with facility structures, systems, or components or with personnel).

Consequence. This column identifies the potential effects of the hazardous condition and potential accident in terms of radioactive or hazardous material releases and impact to personnel and facility systems, structures, and components.

Credited prevention. This column lists preventive safety features present within the facility that are credited with reducing the frequency of the hazard or accident. The credited features listed in this column (both engineered and administrative) include only the controls the accident analyst required to be implemented to support the actual accident analysis. These preventive controls (along with the mitigative controls) are those controls necessary to meet evaluation guidelines.

Frequency code. Two evaluations of the likelihood of occurrence of the hazardous condition and potential accident are listed in this column. The first frequency code subcolumn ranks the hazard and accident frequency by considering the impact of any passive features (e.g., structures, barriers) listed in the table but not the impact of active features or planned controls (e.g., valves, shipping restrictions). The second frequency code subcolumn ranks the hazardous condition and potential accident frequency considering all credited preventive controls, including passive controls. The assessment of likelihood was a collective, qualitative judgment made by the hazard analysis team. The likelihood assessments resulted in frequency rankings based on the initiating event frequencies and subsequent failures on a per-year basis. The qualitative criteria for likelihood assessments are as follows. 
F3 The hazardous condition based on the causes postulated is likely to occur during the facility lifetime.

F2 The hazardous condition based on the causes postulated is foreseeable, but unlikely.

F1 The hazardous condition based on the causes postulated is perhaps possible, but extremely unlikely.

F0 The hazardous condition based on the causes postulated is considered too improbable to warrant further consideration.

Credited mitigation. This column lists mitigative safety features present within the facility that are credited with reducing the consequence of the hazard. The credited features listed in this column (both engineered and administrative) include only the controls the accident analyst required to be implemented to support the actual accident analysis. These mitigative controls (along with the preventive controls) are those controls necessary to meet evaluation guidelines. In some cases a control may reduce both the frequency and the consequence of a hazard.

Consequence code. Two evaluations of the potential effects of the hazardous condition on the health and safety of people and on the environment are listed in this column. The first consequence code subcolumn ranks the hazard and accident consequence by considering the impact of any passive features (e.g., structures, barriers) listed in the table but not the impact of active features or planned controls (e.g., valves, shipping restrictions). The second consequence code subcolumn ranks the hazardous condition and potential accident consequence with all credited mitigative controls, including passive controls. The assessment of the consequence for each hazardous condition was a collective, qualitative judgment made by the hazard analysis team. The qualitative criteria for consequence assessments are as follows.

S3 On the basis of material at risk and causes postulated, there is sufficient material and release energy to affect a receptor at the nearest point of uncontrolled public access.

S2 On the basis of material at risk and causes postulated, there is sufficient material and energy to affect an onsite receptor (collocated worker) $100 \mathrm{~m}$ from the source of the release.

S1 On the basis of material at risk and causes postulated, the release is confined to the facility and affects facility workers.

So On the basis of material at risk and causes postulated, there is insufficient material released to affect facility workers. 


\section{HNF-SD-SNF-HIE-004 REV 5}

The more severe conșequence categories encompass the less severe consequence categories. For example, a hazardous condition assessed as having onsite consequences (S2) is also considered to have facility worker consequences (S1).

Defense in depth for worker safety features. This column contains any additional controls that will reduce the likelihood or consequences even further, but no specific credit is taken for them in the quantitative analysis.

\subsection{CANDIDATE ACCIDENT SELECTION}

The hazardous conditions identified by the hazard evaluation have been used to select candidate accidents for a more detailed, quantitative analysis in the CVDF FSAR (HNF-3553, Annex B). The general selection criteria used were consistent with DOE-STD-3009-94: "The range of accident scenarios analyzed in a SAR should be such that a complete set of bounding conditions to define the envelope of accident conditions to which the operation could be subjected are evaluated and documented."

The team used the four-step process described below to identify specific hazardous conditions that, together, represented the "complete set of bounding conditions" requiring further analysis. In summary, the process involved creating representative sets (or "bins") of hazardous conditions having similar release characteristics, similar initiators, and/or similar controls, and identifying (using the Attachment A, Figure A3-1 ranking matrix) the hazardous condition that represented the most severe consequences and the highest risk in each bin. The highest ranking hazardous condition in each bin bounded the other hazardous conditions in the bin and, therefore, lead to candidate accidents needing further analysis. These hazardous conditions and candidate accidents represent the "complete set of bounding conditions" for the CVDF accident analysis.

The following four-step process was used by the evaluation team to select the CVDF bounding accidents:

1. Initial screening

2. Assignment of release attributes

3. Creation of hazardous material release bins

4. Selection of representative bounding hazardous conditions for each release attribute category.

To capture and record the relational nature of the data developed in the four steps, the results have been organized into two tables, Table A3-1 in Attachment A and Table A4-1 in Attachment B. The following sections describe each step, and identify where in Table A3-1 and Table A4-1 the related information is located. 
Initial Screening. All hazardous conditions with a frequency of F1 (extremely unlikely) or greater and unmitigated consequences assessed as S3 (offsite consequences) or S2 (collocated worker consequences) were chosen for consideration as representative accidents. These hazardous conditions are listed in Table A3-1, with their frequency and consequence rankings listed under the column entitled "Frequency/consequence codes." There were no hazardous conditions assessed as S1 (facility worker consequences) involving radiological hazards requiring detailed accident analysis. The $\mathrm{S} 1$ hazardous conditions are addressed qualitatively in the CVDF FSAR (HNF-3553, Annex B). Hazard conditions having no consequences (S0) were dropped from consideration.

Assignment of Release Attributes. Each hazardous condition was evaluated and described in terms of certain release attributes related to uncontrolled release of the material at risk. This description was assembled to ensure that at least one candidate accident was selected to represent each unique set of release conditions. The following hazardous material release attributes were used:

- Hazardous source (Attachment A, Table A3-1)

- Hazardous conditions and initiators (Attachment A, Table A3-1).

Creation of Hazardous Material Release Bins. As the hazardous material release attributes were identified, each hazardous condition was assigned to a bin category. Assignment to a bin category was based upon the potential accident release characteristics, initiators, and/or proposed mitigative or preventative controls. Table A3-1 in Attachment 3 lists the bin category assignment for each hazardous condition under the "Bin" column heading. The final step in creating the release attribute bins was to assemble hazardous conditions having the same bin category into a listing. This listing is the basis for Table A4-1, in which the hazardous conditions are grouped into their bin categories under the "Candidate accident" column.

\section{Selection of Representative Bounding Hazardous Conditions for each Release} Attribute Category. Within each bin category, the most severe hazardous condition, considering consequences, and the highest risk accident were identified using the three-by-three likelihood and consequence ranking matrix described in DOE-STD-3009-94 (see Attachment A, Figure A3-1). In Table A4-1 of Attachment 4, the bin category hazardous conditions are listed in descending order with the highest ranking hazardous condition at the top. In each accident bin, more than one condition may have been required to provide the necessary bounding conditions for a bin. Table A4-1 identifies the bounding condition, or when necessary, bounding conditions for each bin.

Unique hazardous conditions were identified and selected as a part of the accident analysis process. However, the binning process described here provided the basis for identification and selection of those unique conditions. Briefly, at the completion of design basis accident analysis for each bin category, the results were compared with the other hazardous conditions in the original bin to ensure that no unique and unanalyzed conditions existed. 


\subsection{HAZARD ANALYSIS SUMMARY}

The final list of candidate accidents includes all hazardous conditions with a frequency of $\mathrm{F} 1$ (extremely unlikely) or greater and whose unmitigated consequences were assessed as S3 (offsite consequences) or S2 (collocated worker consequences). Attachment 4, Table A4-1 provides the final list of candidate accidents. The table also identifies the hazardous condition, or conditions, chosen as representative and bounding of all other conditions listed in the bin.

\subsection{REFERENCES}

AIChE, 1985, (Huidelines for Hazard Evaluation Procedures, American Institute of Chemical Engineers

DOE Order 5480.23, Nuclear Safety Analysis Reports, U.S. Department of Energy, Washington, D.C.

DOE-STD-3009-94, 1994, Preparation Guide for U.S. Department of Energy Nonreactor Nuclear Facility Safety Analysis Reports, U.S. Department of Energy, Washington, D.C.

HNF-3553, 2000, Spent Nuclear Fuel Project Final Safety Analysis Report, Rev. 0-A, Fluor Hanford, Incorporated, Richland, Washington.

HNF-PRO-704, Hazard and Accident Analysis Process, Fluor Daniel Hanford, Incorporated, Richland, Washington.

HNF-SD-SNF-SARR-005, 2000, Multi-('amister ( verpack Topical Report, Rev. 2, Fluor Hanford, Incorporated, Richland, Washington.

HNF-SD-TP-SARP-017, 2000, Safety Analysis Report for Packaging (Onsite) Multi-Canister Overpack (ask, Rev. 2, Fluor Hanford, Incorporated, Richland, Washington.

SNF-2356, 2000, Spent Nuclear Fuel Project Cold Vacuum Drying Facility (Operations Manual, Rev. 1, Fluor Hanford, Incorporated, Richland, Washington.

SNF-4268, 1999, Fire Hazard Analysis for the Cold Vacuum Drying Facility, Rev. 0, Fluor Daniel Hanford, Incorporated, Richland, Washington.

SNF-4942, 1999, Spent Nuclear. Fuel Cold Vacuum Drying Facility Implementation Plan for Fire Hazard Analysis Suggested Actions, Rev. 0, Fluor Daniel Hanford, Incorporated, Richland, Washington. 
Figure 1. Main Areas of the Cold Vacuum Drying Facility.

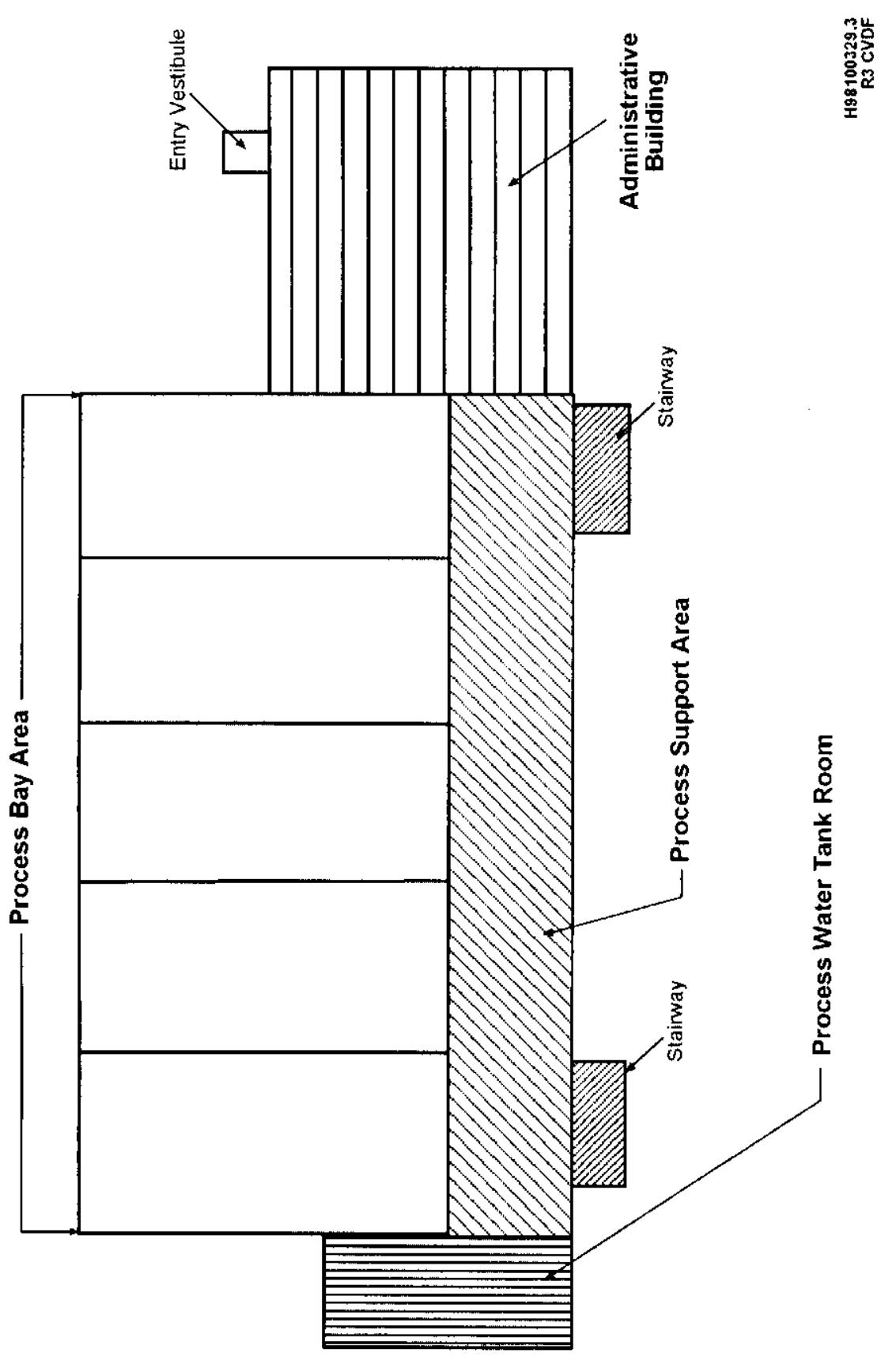




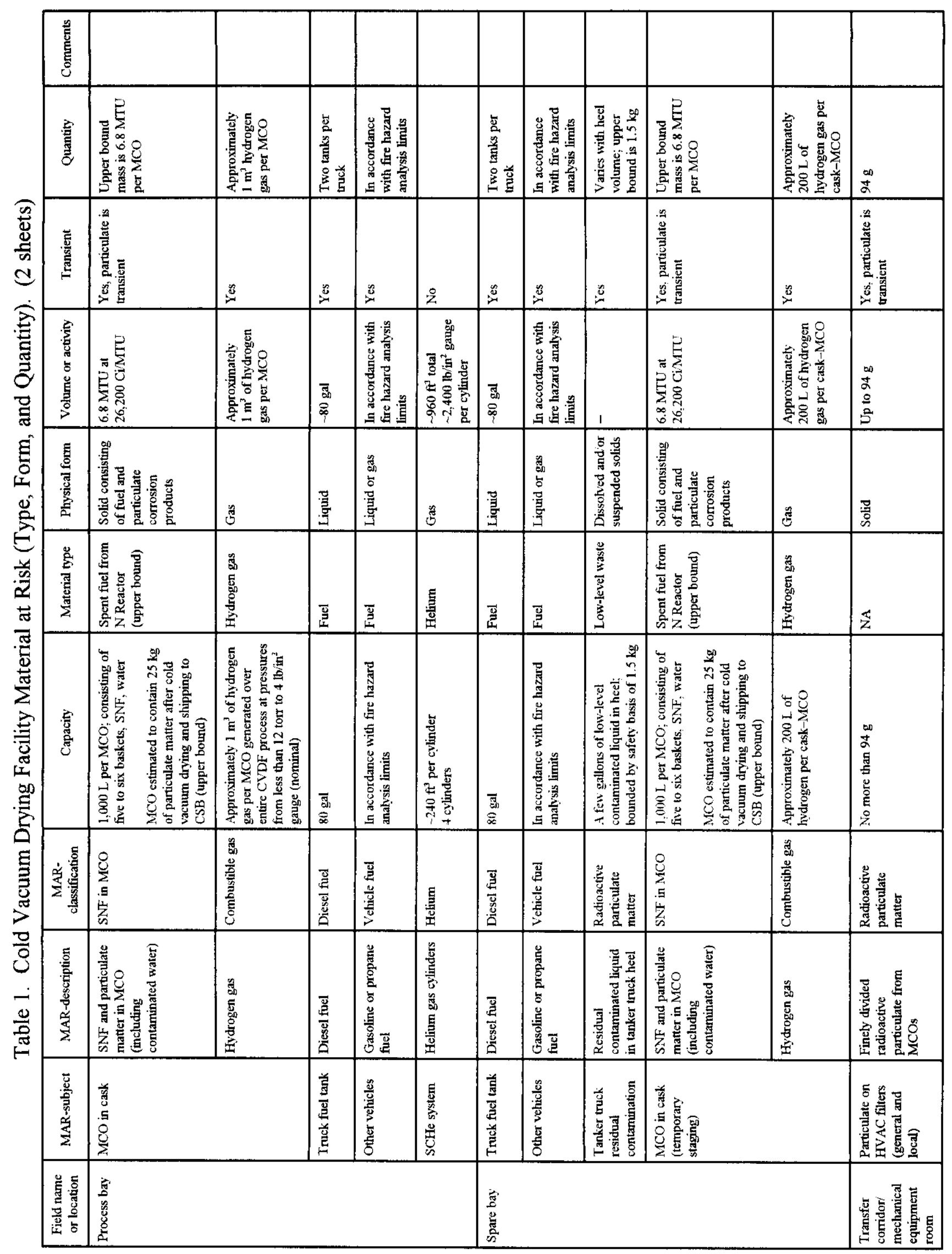




\section{HNF-SD-SNF-HIE-004 REV 5}

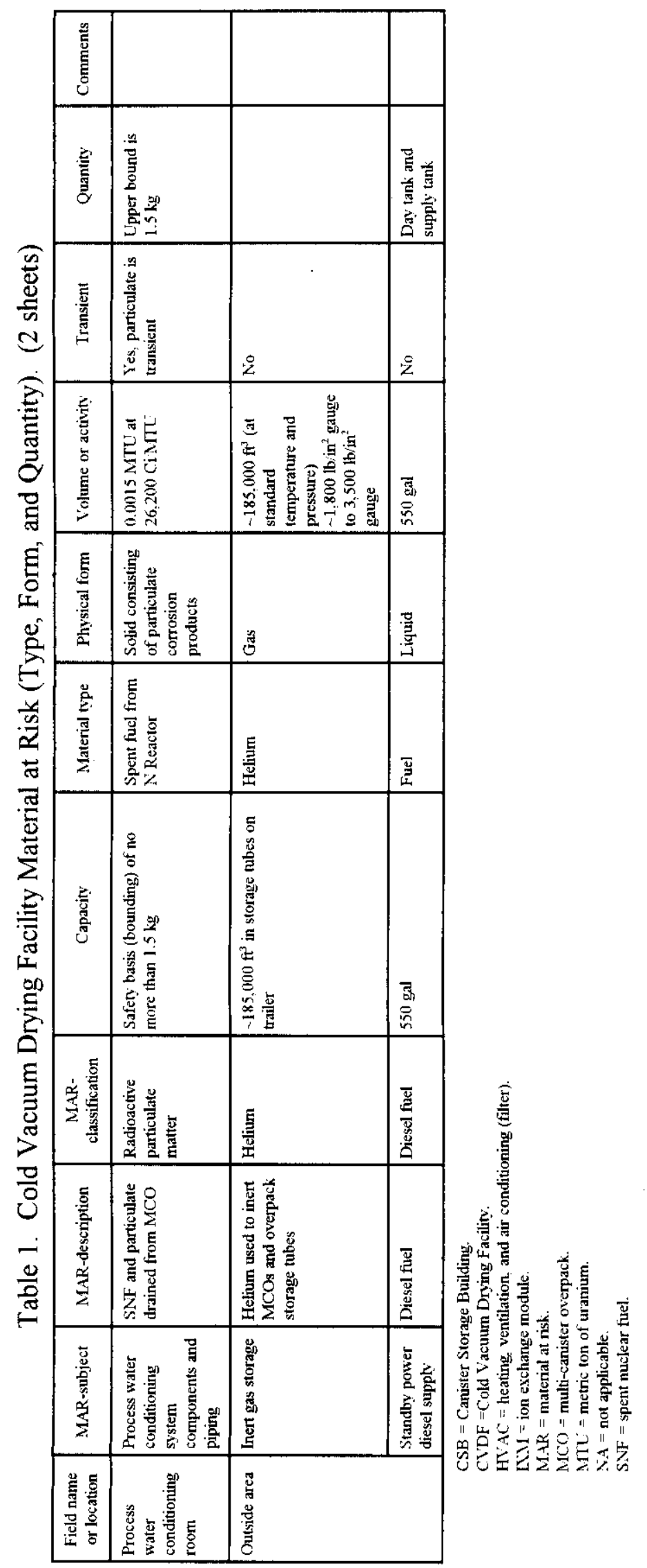



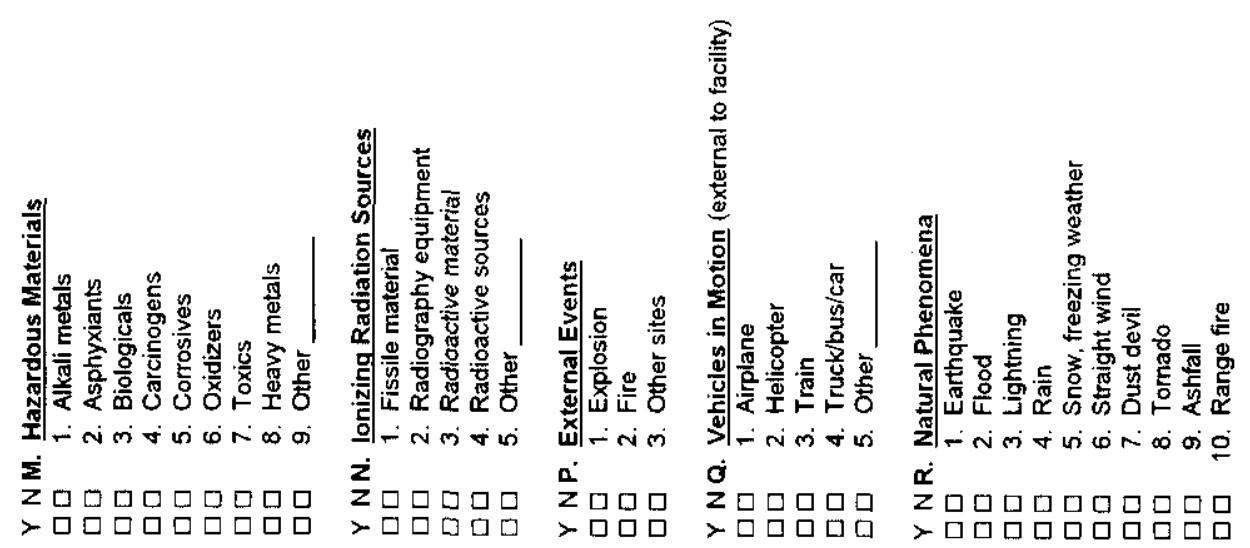

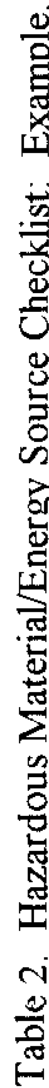
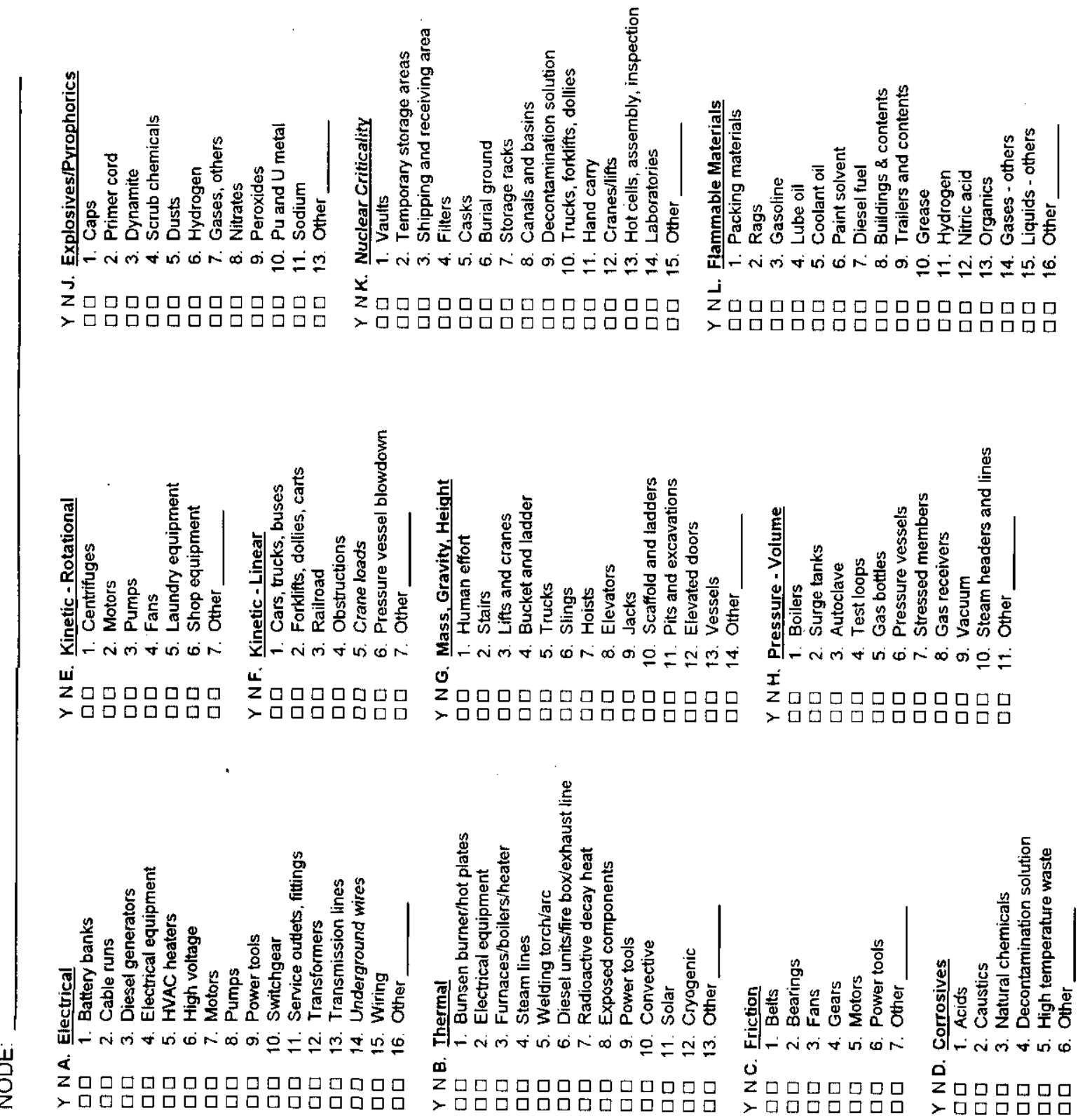


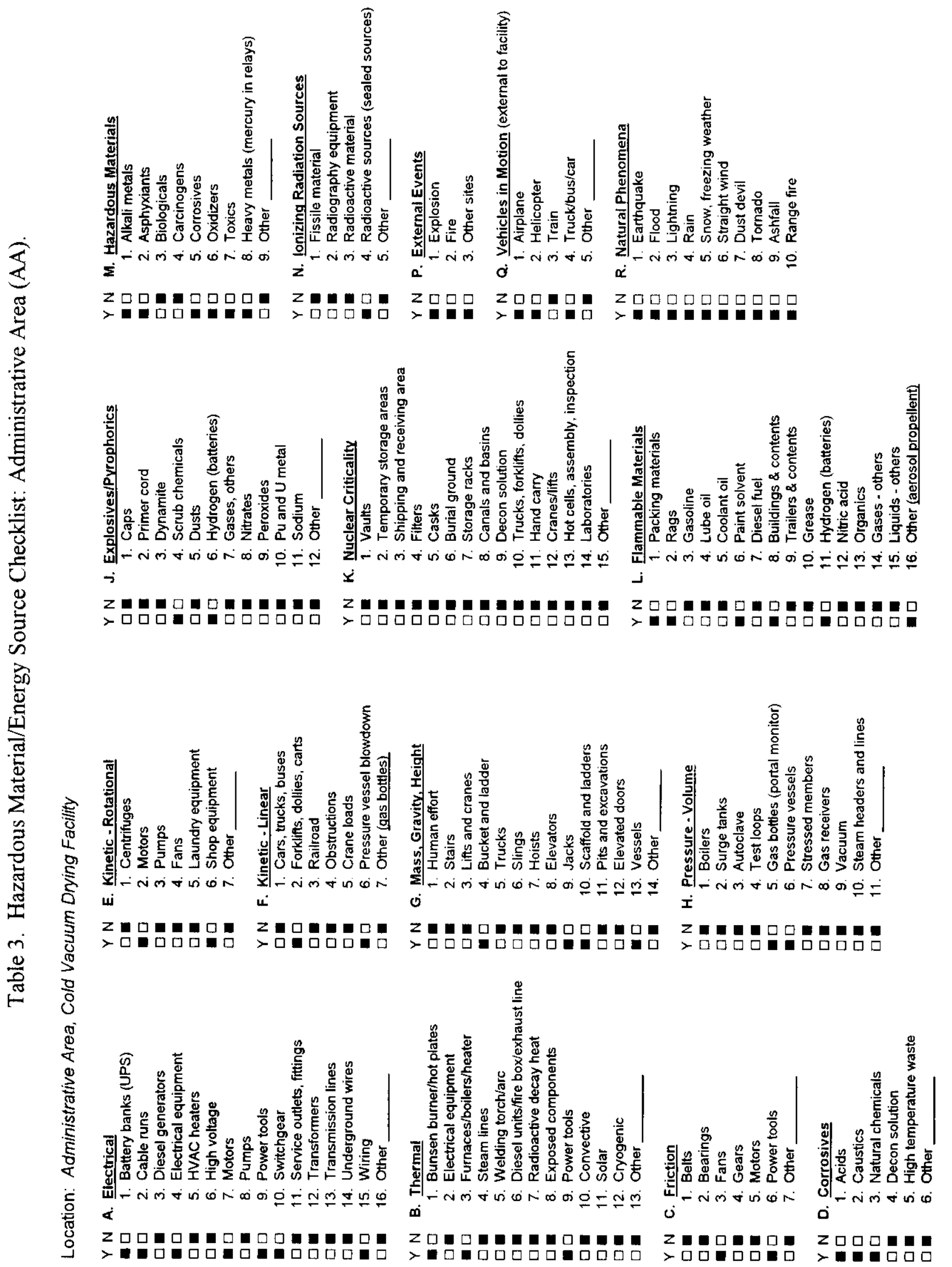


HNF-SD-SNF-HIE-004 REV 5

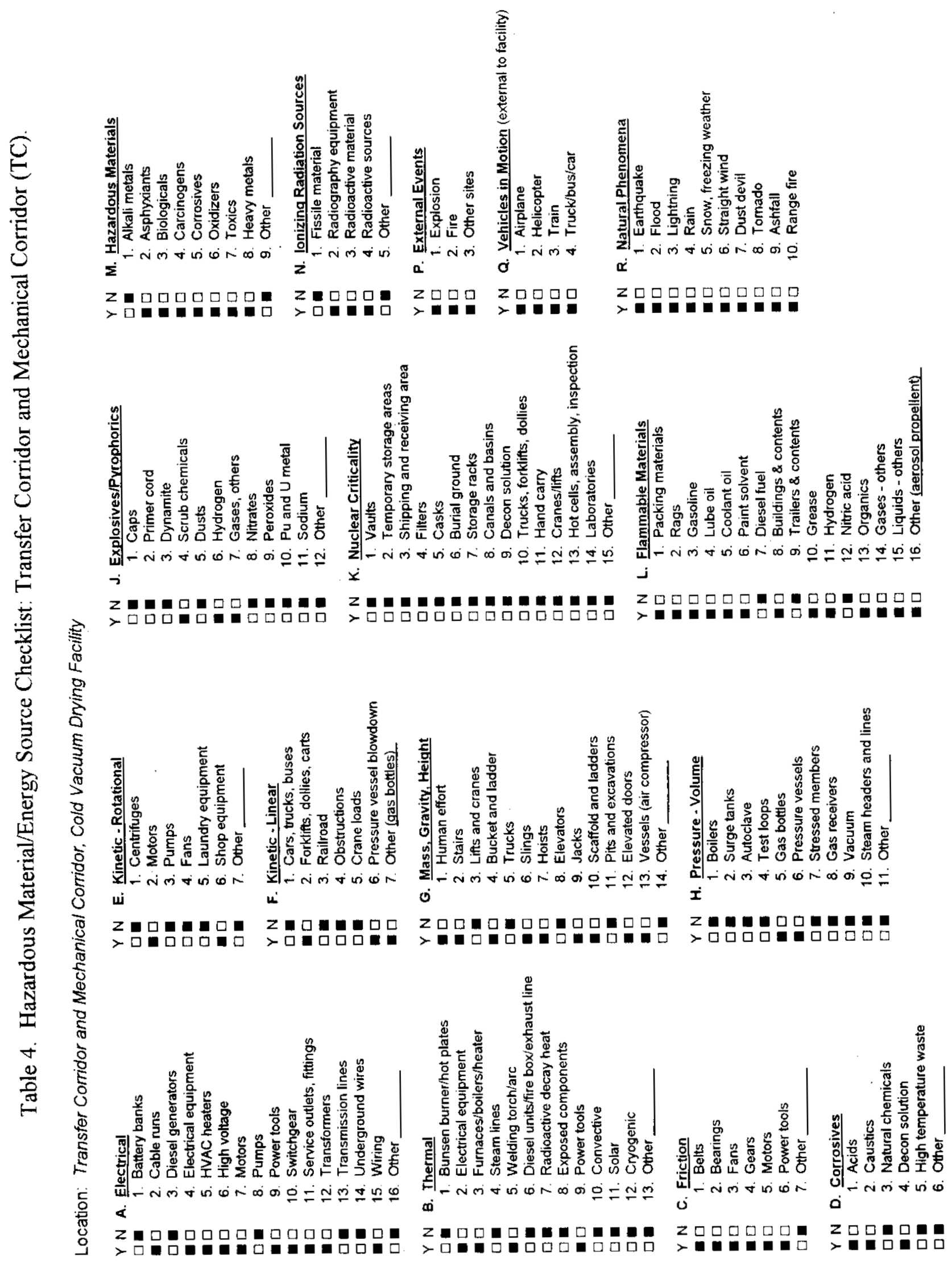




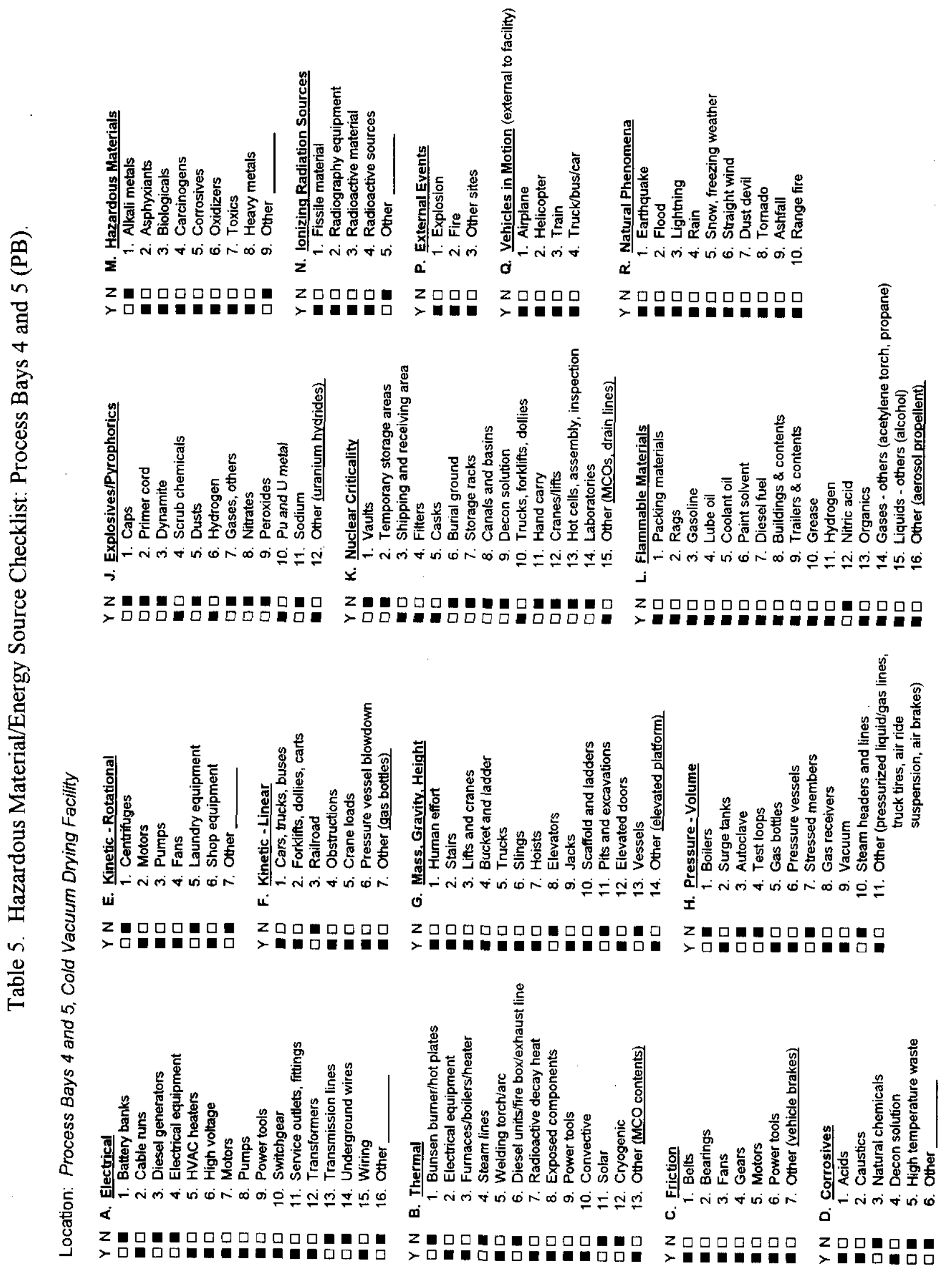




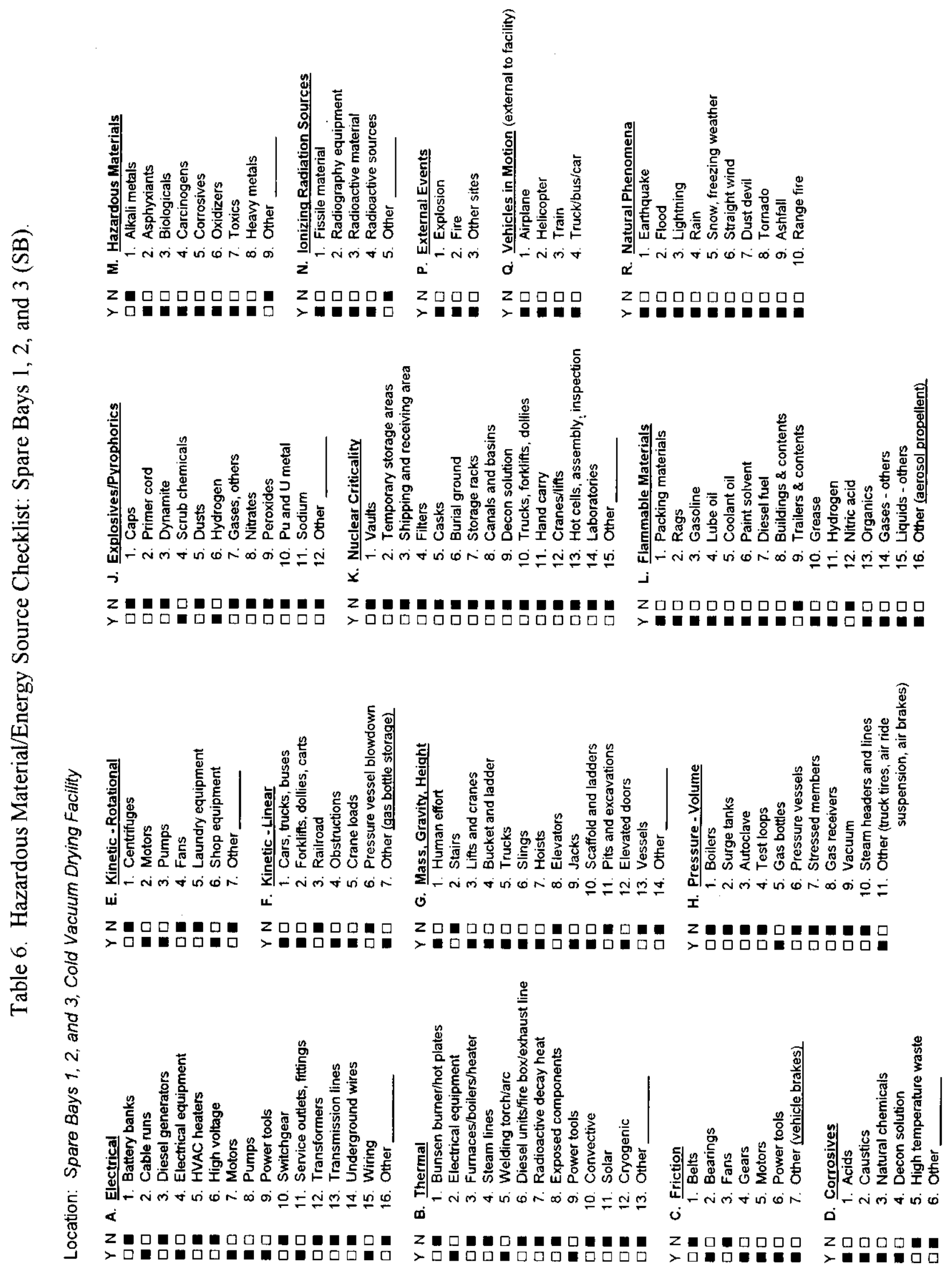




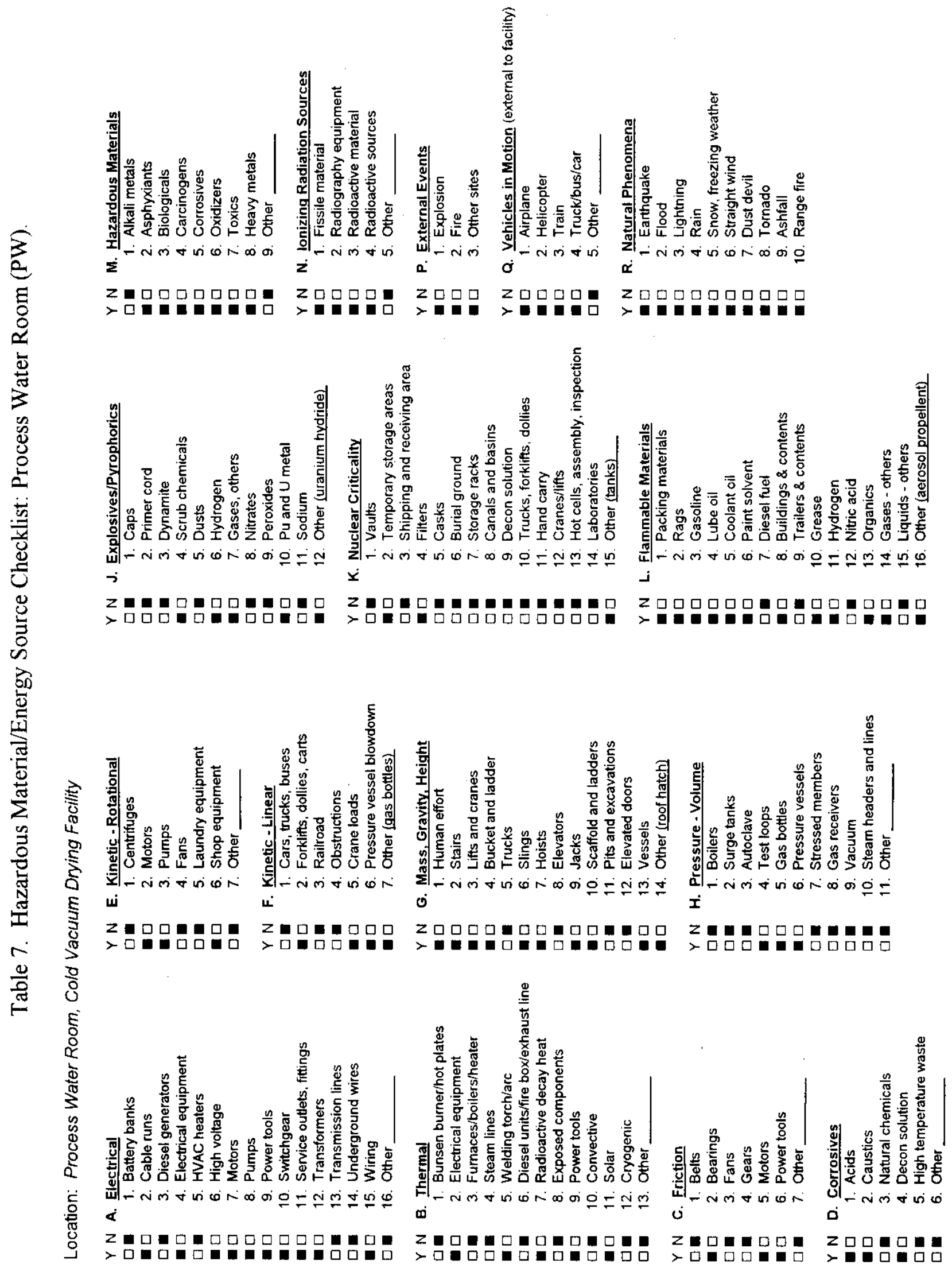




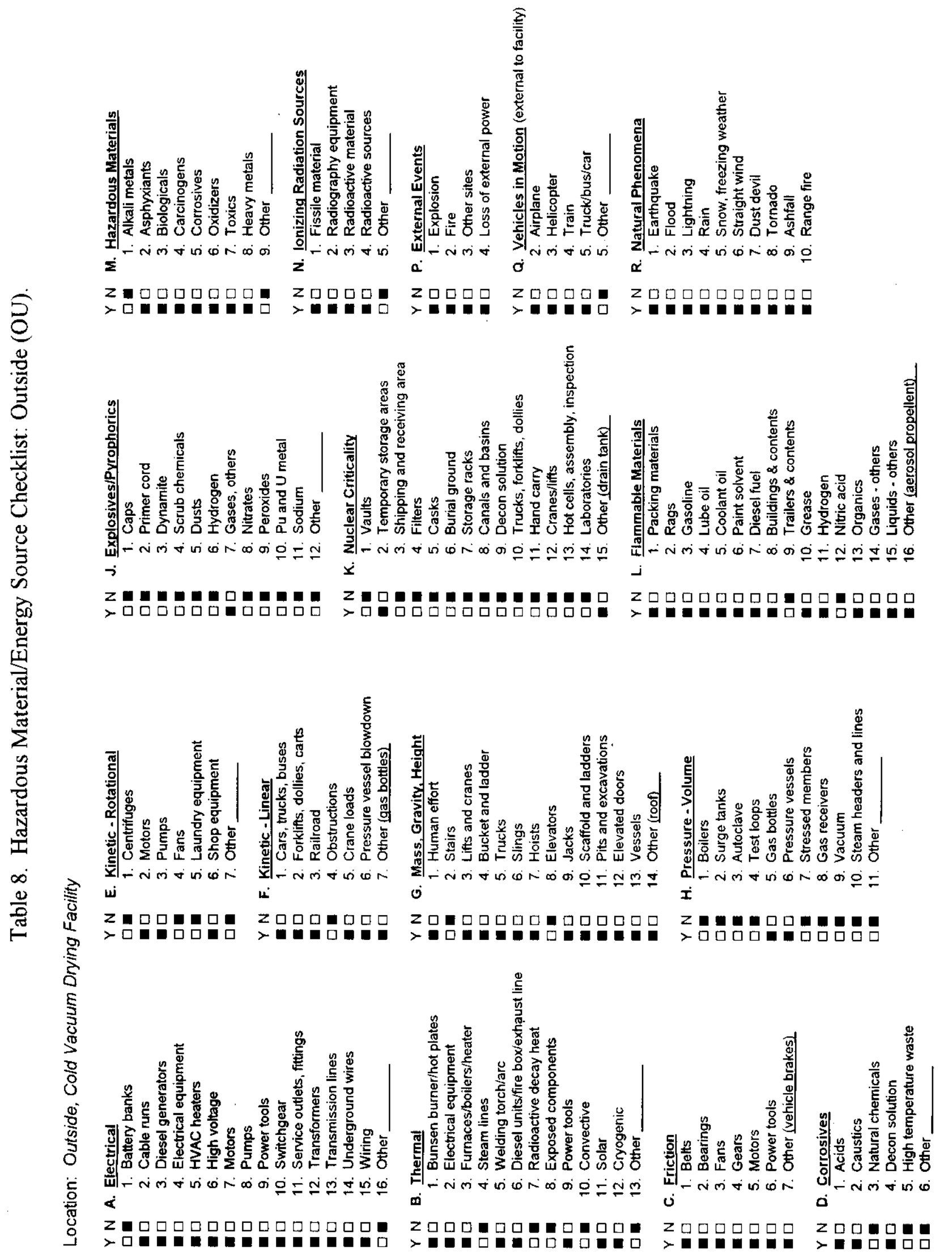


HNF-SD-SNF-HIE-004 REV 5

Table 9. Standard Industrial Hazards: Administrative Area. (2 sheets)

\begin{tabular}{|c|c|c|}
\hline Hazard category & Hazand type & $\begin{array}{l}\text { I Iazard checklist } \\
\text { identification } \\
\text { number* }\end{array}$ \\
\hline \multirow[t]{7}{*}{ Electrical } & Battery banks (uninterruptible power stupply) & $\mathrm{AA}-\mathrm{A}-() \mathrm{l}$ \\
\hline & Cable runs & $\mathrm{AA}-\mathrm{A}-() 2$ \\
\hline & Electrical equipment & $\mathrm{AA}-\mathrm{A}-(04$ \\
\hline & Motors & $\mathrm{AA}-\mathrm{A}-(07$ \\
\hline & Power tools & $\mathrm{AA}-\mathrm{A}-(09$ \\
\hline & Switchgear & AA-A-10 \\
\hline & Wiring & $A A-A \cdot 15$ \\
\hline \multirow[t]{3}{*}{ Thermal } & Bunsen bumer/hot plates & $A A-B-01$ \\
\hline & Furnaces/boilers/heater & $\triangle A-B-(33$ \\
\hline & Power tools & AA-B-09 \\
\hline \multirow[t]{2}{*}{ Friction } & Falls & $\triangle \mathrm{A}-\mathrm{C}-0.3$ \\
\hline & Power tools & $\mathrm{AA}-\mathrm{C}-0 \mathrm{G}$ \\
\hline \multirow[t]{3}{*}{ Corrosives } & Acids & $\Lambda \wedge-1)-() 1$ \\
\hline & Calustics & $A A-D-() 2$ \\
\hline & Natural chemicals & $\wedge \wedge-D-03$ \\
\hline \multirow[t]{2}{*}{ Kinetic-rotational } & Motors & $\triangle \wedge-E-() 2$ \\
\hline & Shop equipment & $\triangle A-1 \pm-06$ \\
\hline Kinetic - linear & lorklilts, dollies, carts & $\mathrm{AA}-\mathrm{F}-() 2$ \\
\hline \multirow[t]{4}{*}{ Mass, gravity, height } & Bucket and ladder & $A A-(i-() 4$ \\
\hline & Jacks & $A A-(i-0)$ \\
\hline & Scalfold and ladders & $\triangle \wedge-(\mathrm{j}-10$ \\
\hline & Vessicls & $A A-(j-13$ \\
\hline \multirow[t]{2}{*}{ Pressure - volume } & (ras bottles (portal monitor) & AA-H-05 \\
\hline & Pressure vessels & $\mathrm{AA}-\mathrm{H}-\mathrm{O}(\mathrm{G}$ \\
\hline Explosives/pyrophorics & Scrub chemicals & $\Lambda \wedge-J-() 4$ \\
\hline \multirow[t]{6}{*}{ Hazardous materials } & Alkali metals & $\mathrm{A} \wedge-\mathrm{M}-01$ \\
\hline & Asphysiants & $\triangle A-M-() 2$ \\
\hline & Corrosives & $\wedge \wedge-\mathrm{M}-05$ \\
\hline & Oxidizers & $\mathrm{AA}-\mathrm{M}-() 6$ \\
\hline & Toxics & $A A-M-07$ \\
\hline & Heavy metals (mercury in relays) & $\triangle A-M-08$ \\
\hline
\end{tabular}


HNF-SD-SNF-HIE-004 REV 5

Table 9. Standard Industrial Hazards: Administrative Area. (2 sheets)

\begin{tabular}{|l|l|c|}
\hline Hazard category & llazard type & $\begin{array}{c}\text { llazard checklist } \\
\text { identitication } \\
\text { number* }\end{array}$ \\
\hline Ionizing radiation sources & Radicactive sources (scaled sources) & AA-N-(04 \\
\hline
\end{tabular}

*Hazard checklist identification numbers XX-Y-\#\# represent a specific line item on a hazardous material/energy source checklist ( see 'Table 2) where:

$\mathrm{XX}=$ facility area.

$\mathrm{Y}=$ hazard type

\#\# = checklist designator. 
HNF-SD-SNF-HIE-004 REV 5

Table 10. Standard Industrial Hazards: Transfer Corridor and Mechanical Corridor. (2 sheets)

\begin{tabular}{|c|c|c|}
\hline Hazard category & Hazard type & $\begin{array}{c}\text { Hazard checklist } \\
\text { identification } \\
\text { number* }\end{array}$ \\
\hline \multirow[t]{10}{*}{ Electrical } & C'able runs & $\mathrm{TC}-\mathrm{A}-() 2$ \\
\hline & Electrical equipment & $\mathrm{TC}-\mathrm{A}-() 4$ \\
\hline & HVAC heaters & TC-A-05 \\
\hline & High voltage & $T C-A-() 6$ \\
\hline & Motors & TC-A-07 \\
\hline & l'ower tools & {$[(C-A-())$} \\
\hline & Switchgear & $\mathrm{TC}-\mathrm{A}-10$ \\
\hline & Service outlets, littings & TC $-\mathrm{A}-11$ \\
\hline & Transformers & $\Gamma C-A-12$ \\
\hline & Wiring & $T C-A-15$ \\
\hline \multirow[t]{3}{*}{ Thermal } & Electrical equipment & $T(-B-() 2$ \\
\hline & Funnaces/hoilers/healer & $\mathrm{T} C \mathrm{C}-\mathrm{B}-\mathrm{-03}$ \\
\hline & P'ower tools & ТC-B-()9 \\
\hline \multirow[t]{6}{*}{ Friction } & Belts & $\mid \mathrm{IC}-\mathrm{C}-01$ \\
\hline & Bearings & $\mathrm{TC}-\mathrm{C}-(\mathrm{O} 2$ \\
\hline & Fans & TC-C-03 \\
\hline & (icars & $\mathrm{TC}-\mathrm{C}-(04$ \\
\hline & Motors & $\mathrm{TC}-\mathrm{C}-05$ \\
\hline & Power tools & $\mathrm{TC}-\mathrm{C}-06$ \\
\hline \multirow[t]{3}{*}{ Corrosives } & Acids & $T(-1)-01$ \\
\hline & Caustics & {$[(-1)-() 2$} \\
\hline & Decon solution & TC:-1)-()4 \\
\hline \multirow[t]{2}{*}{ Kinetic - rotational } & Motors & TC $-\mathrm{I}-() 2$ \\
\hline & Shop equipment & TC-E- 06 \\
\hline \multirow[t]{9}{*}{ Mass, gravity, height } & I luman eflort & TC-(3-0) \\
\hline & Stairs & $\mathrm{T}^{\prime} \mathrm{C}-\mathrm{(i}-(\mathrm{)})$ \\
\hline & Bucket and ladder & $\mathrm{TC}-(\mathrm{i}-() 4$ \\
\hline & Slings & $\mathrm{TC}-\mathrm{C}-(\mathrm{)})$ \\
\hline & Hoists & TC-(y-()7 \\
\hline & Jacks & $\mathrm{TC}-\mathrm{G}-09$ \\
\hline & Scaftold and ladders & $\mathrm{TC}-(\mathrm{Y}-\mathrm{lO}$ \\
\hline & Elevated doors & $\mathrm{TC}-\mathrm{G}-12$ \\
\hline & Vessels (air compressor) & TC-(i-13 \\
\hline
\end{tabular}


HNF-SD-SNF-HIE-004 REV 5

Table 10. Standard Industrial Hazards: Transfer Corridor and Mechanical Corridor. (2 sheets)

\begin{tabular}{|c|c|c|}
\hline Hazard category & Tazard type & $\begin{array}{l}\text { Hazard checklist } \\
\text { identification } \\
\text { number* }\end{array}$ \\
\hline \multirow[t]{2}{*}{ Pressure - volume } & (ius bottles & $\mathrm{TC}-\mathrm{H}-05$ \\
\hline & Pressure vessels & $\mathrm{TC}-\mathrm{H}-\mathrm{O}) \mathrm{G}$ \\
\hline \multirow[t]{3}{*}{ Explosives/pyrophorics } & Scrub chemicals & $\mathrm{I}^{\prime} \mathrm{C}^{\prime}-\mathrm{J}-() 4$ \\
\hline & I. lydrogen & $\mathrm{I}^{\prime} \mathrm{C}-\mathrm{J}-\mathrm{J}-06$ \\
\hline & Gases, others & TC-.J-07 \\
\hline \multirow[t]{3}{*}{ Flammable Materials } & Grealse & $10(-1,-10$ \\
\hline & (iasoline & TC-L-(03 \\
\hline & Organics & $\mathrm{TC}-1,-13$ \\
\hline \multirow[t]{7}{*}{ Hazardous materials } & Asphyxiants & [C-M-()2 \\
\hline & Biologicals & $\mathrm{TC}-\mathrm{M}-03$ \\
\hline & Carcinogens & TC-M-()4 \\
\hline & Corrosives & $\mathrm{TC}-\mathrm{M}-05$ \\
\hline & Oxidizers & TC-M-OG \\
\hline & Toxics & $T C-M-07$ \\
\hline & Ileavy metals & TC-M-O) \\
\hline \multirow[t]{2}{*}{ Ionizing radiation sources } & Radiography equipment & {$[C-N-() 2$} \\
\hline & Radionctive sources & $T C-N-() 4$ \\
\hline $\begin{array}{l}\text { Vehicles in motion } \\
\text { (external to facility) }\end{array}$ & Train & $\mathrm{TC}-\mathrm{Q}-03$ \\
\hline
\end{tabular}

*Hazard checklist identification numbers XX-Y -\#\# represent a specitic line item on a harardous material/energy source checklist (see Table 2) where:

$\mathrm{XX}=$ facility area.

$\mathrm{Y}=$ hazard type.

\#\# = checklist designator. 
HNF-SD-SNF-HIE-004 REV 5

Table 11. Standard Industrial Hazards: Process Bays. (2 sheets)

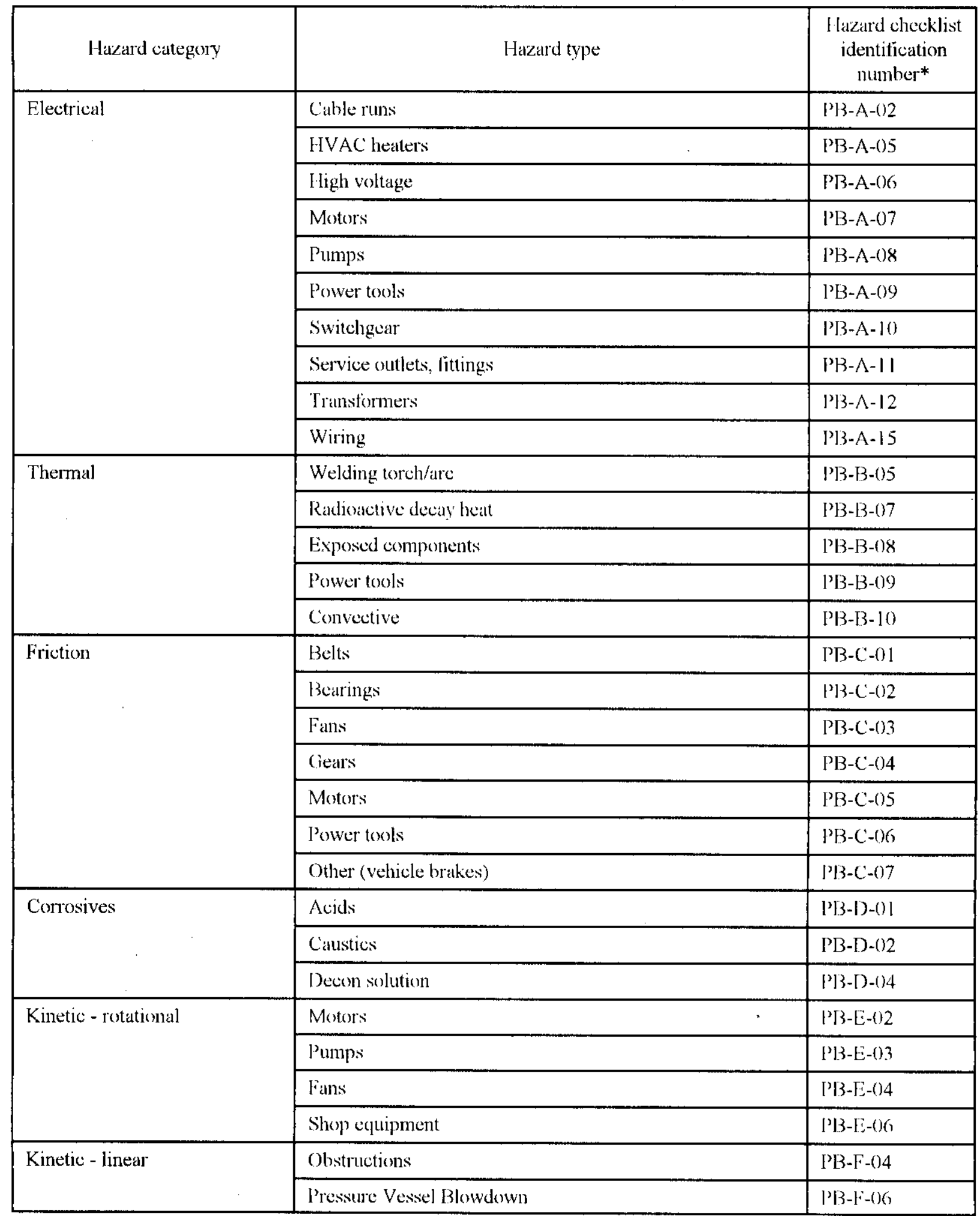


HNF-SD-SNF-HIE-004 REV 5

Table 11. Standard Industrial Hazards: Process Bays. (2 sheets)

\begin{tabular}{|c|c|c|}
\hline Hazard category & Hazurd type & $\begin{array}{l}\text { Hazard checklist } \\
\text { identification } \\
\text { number* }\end{array}$ \\
\hline \multirow[t]{11}{*}{ Mass, gravity, height } & Human effort & $P B-(i-0)$ \\
\hline & Stairs & $P B-(i-0) 2$ \\
\hline & Lifts and cranes & $P B-(i-0) 3$ \\
\hline & Buckel and ladder & P'B-( $\mathrm{Y}-(\mathrm{)} 4$ \\
\hline & Trucks & PB-(i-()5 \\
\hline & Slings: & $P] 3-(i-0) 6$ \\
\hline & 1 loists & PB-(i-()7 \\
\hline & Jatcks & $\mathrm{P} P 3-(\mathrm{i}-() 9$ \\
\hline & Scaffold and ladders & P'B-(i-10) \\
\hline & Elevaled doors & ['B-Ci-12 \\
\hline & (other (elevated platiorm) & $P B-(i-14$ \\
\hline \multirow[t]{4}{*}{ Pressure - volume } & Surge tanks & I'B-H-(0) \\
\hline & Gas bottles & PB-H-05 \\
\hline & Gas receivers & PB-H-(OX \\
\hline & Vacuum & P'B-H-(0) \\
\hline Explosives/pyrophories & Scrub chemicals & {$[2 \mathrm{~B}-. \mid-(04$} \\
\hline \multirow[t]{2}{*}{ Nuclear criticality } & Shipping and receiving area & $P^{\prime} B-K-03$ \\
\hline & Trucks, forklifts, dollies & $\Gamma \mathrm{B}-\mathrm{K}-10$ \\
\hline \multirow[t]{7}{*}{ Hazardous materials } & Asphyxiants & l'B-M-()2 \\
\hline & Biologicals & l'B-M-03 \\
\hline & Carcinogens & l'B-M-()4 \\
\hline & Corrosives & P'13-M-015 \\
\hline & Oxidizers & ]'B-M-()6 \\
\hline & Toxics & P'B-M-07 \\
\hline & Ileavy metals & Pl3-M-()R \\
\hline \multirow[t]{2}{*}{ Iomizing radiation sources } & Radiography equipment & {$[3-\mathrm{B}-\mathrm{N}-(1) 2$} \\
\hline & Radioactive sources & PBB-N-(04 \\
\hline External events & Fire & $P^{\prime}\left(3-I^{\prime}-() 2\right.$ \\
\hline
\end{tabular}

*Hazard checklist identification numbers XX-Y-\#\# represent a specific line item on a hazardous material/energy source checklist (see Table 2) where:

$\mathrm{XX}=$ facility area.

$\mathrm{Y}=$ hazard type.

\#\# = checklist designator. 
HNF-SD-SNF-HIE-004 REV 5

Table 12. Standard Industrial Hazards: Spare Bays. (2 sheets)

\begin{tabular}{|c|c|c|}
\hline Hazard category & lakard type & $\begin{array}{l}\text { I lazard checklist } \\
\text { identification } \\
\text { number* }\end{array}$ \\
\hline \multirow[t]{7}{*}{ Electrical } & Ciable runs & $S \mathrm{~B}-\mathrm{A}-() 2$ \\
\hline & Electrical equipment & SB-A-()4 \\
\hline & Motors & $S B-\Lambda-07$ \\
\hline & l'umps & $S I 3-A-08$ \\
\hline & l'ower tools & $\mathrm{S}[3-\mathrm{A}-(0)$ \\
\hline & Service outlets, littings & $S B-A-I 1$ \\
\hline & Wiring & SB-A-15 \\
\hline \multirow[t]{3}{*}{ Thermal } & Electrical equipment & $\mathrm{SB}-\mathrm{B}-(\mathrm{)} 2$ \\
\hline & Welding torch/arc & $\mathrm{S} B 3-B-() 5$ \\
\hline & Power tools & SB-B-(3) \\
\hline \multirow[t]{5}{*}{ Friction } & [3earings & $S B-C-(02$ \\
\hline & Gears & $S B-C-(0) 4$ \\
\hline & Motors & $\mathrm{SB}-\mathrm{C}-(05$ \\
\hline & Power tools & $S B-C-() 6$ \\
\hline & Other (vehicle brakes) & $S B-C-07$ \\
\hline \multirow[t]{4}{*}{ Corrosives } & Acids & $S B-I)-(0]$ \\
\hline & Calustics & $S B-D-() 2$ \\
\hline & Natural chemicals & $S B-D-() 3$ \\
\hline & Decon solution & $S B-I)-(14$ \\
\hline \multirow[t]{3}{*}{ Kinetic - rotational } & Motors & $S B-1 ;-(1) 2$ \\
\hline & Pumps & SB-E- $(0) 3$ \\
\hline & Shop equipment & SSB-E-()6 \\
\hline \multirow[t]{2}{*}{ Kinetic - linear } & (obstruction & SB-F-(04 \\
\hline & Crane loads & $\mathrm{S} B-\mathrm{I}^{2}-05$ \\
\hline \multirow[t]{9}{*}{ Mass, gravity, height } & Human effort & $S B-(\mathrm{B}-0) 1$ \\
\hline & Lifts and cranes & $\mathrm{SB}-\mathrm{C}-0) 3$ \\
\hline & Bucket and ladder & $\mathrm{SB} 3-(\mathrm{j}-() 4$ \\
\hline & Trucks & $\mathrm{S} 13-(i-0) 5$ \\
\hline & Slings & $S B-(i-0) 6$ \\
\hline & Iloists & $S B-(i-0) 7$ \\
\hline & Jackis & $S B-(i-0)$ \\
\hline & Scutfold and ladders & $S B-(i-10$ \\
\hline & Flevaled doors & $S B-(i-12$ \\
\hline
\end{tabular}


HNF-SD-SNF-HIE-004 REV 5

Table 12. Standard Industrial Hazards: Spare Bays. (2 sheets)

\begin{tabular}{|c|c|c|}
\hline Hazard category & Hazard type & $\begin{array}{l}\text { Hazard checklist } \\
\text { identilication } \\
\text { number* }\end{array}$ \\
\hline Pressure - volume & Gas bottles & $\mathrm{si3-11-05}$ \\
\hline \multirow[t]{2}{*}{ Explosives/pyrophorics } & Scrub chemicals & $S B-J-() 4$ \\
\hline & Hydrogen & $S B-I-O) 6$ \\
\hline \multirow[t]{2}{*}{ Flammable materials } & Grease & SB-L-10 \\
\hline & Organics & $S 13-1 .-13$ \\
\hline \multirow[t]{7}{*}{ Hazardous materials } & Asphyxiants & $S B-M-() 2$ \\
\hline & Biologicals & $S 13-M-() 3$ \\
\hline & Carcinogens & $S B-M-() 4$ \\
\hline & Corrosives & $S(3-M-6) 5$ \\
\hline & Oxidizers & $S 13-M-(36$ \\
\hline & Toxics & $S[3-M-07$ \\
\hline & I leavy metals & $S B-M-08$ \\
\hline \multirow[t]{2}{*}{ Ionizing radiation sources } & Radiography equipment & $\mathrm{S} B-\mathrm{N}-(02$ \\
\hline & Radioactive sources & $S B-N-() 4$ \\
\hline $\begin{array}{l}\text { Vehicles in motion } \\
\text { (external to facility) }\end{array}$ & Train & $S B-Q-0.3$ \\
\hline
\end{tabular}

* Hazard checklist identification numbers XX-Y-\#\# represent a specilic line item on a ba/ardous material/energy source checklist (see Table 2) where:

$$
\begin{aligned}
& X X=\text { facility area. } \\
& Y=\text { hazard type. } \\
& \# \#=\text { checklist designator. }
\end{aligned}
$$


HNF-SD-SNF-HIE-004 REV 5

Table 13. Standard Industrial Hazards: Process Water Room. (2 sheets)

\begin{tabular}{|c|c|c|}
\hline Hazard category & H lazard type & $\begin{array}{c}\text { Harard checklist } \\
\text { identification } \\
\text { number* }\end{array}$ \\
\hline \multirow[t]{10}{*}{ Electrical } & Cable runs & $P W-\wedge-02$ \\
\hline & Electrical equipment & $P^{\prime} W-\Lambda-() 4$ \\
\hline & High voltage & {$[\mathrm{W}-\mathrm{A}-0 \mathrm{G}$} \\
\hline & Motots & PW-A-07 \\
\hline & Pumps & $P W-A-() 8$ \\
\hline & Power tools & I'W-^-09 \\
\hline & Switchgear & PW-A-10 \\
\hline & Service outlets, tittings & PW-A-11 \\
\hline & Transtormers & PW-A-12 \\
\hline & Wiring & PW-A-15 \\
\hline \multirow[t]{5}{*}{ Thermal } & Electrical equipment & $\mathrm{PW}-\mathrm{B}-(\mathrm{)} 2$ \\
\hline & Welding torch/are & $\mathrm{I}^{2} \mathrm{~W}-\mathrm{B}-05$ \\
\hline & Radioactive decay heat & $\mathrm{PW}-\mathrm{P}-07$ \\
\hline & Power tools & PW-B-(0) \\
\hline & Solar & $12 W-B-11$ \\
\hline \multirow[t]{3}{*}{ Friction } & Bearings & $\mathrm{PW}-\mathrm{C}-02$ \\
\hline & Motors & PW-C-05 \\
\hline & Jower tools & $P W-C-06$ \\
\hline \multirow[t]{3}{*}{ Corrosives } & Acids & l'W-I)-(01 \\
\hline & Caltstics & $1 \times-1)-() 2$ \\
\hline & Decon solution & $P W-P-(04$ \\
\hline \multirow[t]{3}{*}{ Kinetic - rotational } & Motors & $\mathrm{PW}-\mathrm{F}-(1) 2$ \\
\hline & Pumps & PW-E-(1)3 \\
\hline & shop equipment & ['W-E-(1)6 \\
\hline \multirow[t]{3}{*}{ Kinetic - linear } & Forklifts, dollies carts & $\mathrm{P}^{\prime} \mathrm{W}-\mathrm{F}-(1) 2$ \\
\hline & Crane loads & $P W-F-05$ \\
\hline & Pressure vessel blowdown & $P W-1 *-06$ \\
\hline \multirow[t]{6}{*}{ Mass, gravity, height } & Human effort & PW-(i-()I \\
\hline & Stairs & PW-(i-0)2 \\
\hline & Bucket and ladder & l'W-(i-0)4 \\
\hline & Slings & $P W-(j-1) G_{3}$ \\
\hline & Hoists & PW-G-07 \\
\hline & lacks & [DW-(i-()9 \\
\hline
\end{tabular}


HNF-SD-SNF-HIE-004 REV 5

Table 13. Standard Industrial Hazards: Process Water Room. (2 sheets)

\begin{tabular}{|c|c|c|}
\hline Hazard category & I lazard type & $\begin{array}{l}\text { Mazard checklist } \\
\text { identilication } \\
\text { number* }\end{array}$ \\
\hline \multirow[t]{3}{*}{ Mass, gravity, height (cont.) } & Scaffold and ladders & PW-(i-10 \\
\hline & Vessels & PW-G-13 \\
\hline & Other (roof hatch) & PW-Ci-14 \\
\hline \multirow[t]{3}{*}{ Pressure - volume } & Test loops & PW-H-(04 \\
\hline & Gas bottles & PW-11-05 \\
\hline & Pressure vessels & PW-H-1)G \\
\hline \multirow[t]{2}{*}{ Explosives/pyrophorics } & Scrub chemicals & PW-.J-()4 \\
\hline & Gases, other & PW-.J-(07 \\
\hline \multirow[t]{7}{*}{ Flammable materials } & Packing materials & $1] W-[-()]$ \\
\hline & Gasoline & PW-L-03 \\
\hline & Lube oil & I'W-1,-(04 \\
\hline & Coolant oil & $12 W-1,-(1) 5$ \\
\hline & Paint solvent & PW-I,-(1)6 \\
\hline & Grease & PW-I,-10 \\
\hline & Organics & PW-1,-13 \\
\hline \multirow[t]{6}{*}{ Hazardous matcrials } & Aspleyxiants & $\mathrm{PW}-\mathrm{M}-02$ \\
\hline & Biologicals & l'W-M-033 \\
\hline & Carcinogens & l'W-M-(04 \\
\hline & Comrosives & l'W-M-05 \\
\hline & loxics & PW-M-07 \\
\hline & Heavy metals & I'W-M-08 \\
\hline Ionizing radiation sources & Radiography equipment & l'W-N-()2 \\
\hline $\begin{array}{l}\text { Vehicles in motion } \\
\text { (external to facility) }\end{array}$ & Train & $P W-Q-() 3$ \\
\hline Natural phenomena & Earthquake & PW-R-(0) \\
\hline
\end{tabular}

*Hazard checklist identification numbers XX-Y-\#\# represent a specific line item on a hazardous material/energy source checklist (see Table 2) where:

$\mathrm{XX}=$ facility area.

$\mathrm{Y}=$ hazard type.

\#\# = checklist designator 
HNF-SD-SNF-HIE-004 REV 5

Table 14. Standard Industrial Hazards: Outside. (3 sheets)

\begin{tabular}{|c|c|c|}
\hline Hazard category & Haxard type & $\begin{array}{l}\text { Hazard checklist } \\
\text { identification } \\
\text { number }\end{array}$ \\
\hline \multirow[t]{14}{*}{ Electrical } & C'able runs & $(\mathrm{O}-\mathrm{J}-\mathrm{A}-\mathrm{O} 2$ \\
\hline & Diesel generators & $0) \triangle-03$ \\
\hline & Filectrical equipment & ()$(1-\mathrm{A}-() 4$ \\
\hline & HVAC heaters & $(\mathrm{O})-\mathrm{A}-0 \mathrm{5}$ \\
\hline & High voltage & $0(J-A-0) 6$ \\
\hline & Motors & () $\mathrm{U}-\mathrm{A}-0) 7$ \\
\hline & Pumps & () $)-A-0) X$ \\
\hline & l'ower fools & ()$(1-A-0)$ \\
\hline & Switchgear & ()(]$-A-10)$ \\
\hline & Service outlets, fittings & $(\mathrm{U}-\mathrm{A}-11$ \\
\hline & Transtormers & () (J-A-12 \\
\hline & Transinission lines & $\mathrm{OU}-\mathrm{A}-13$ \\
\hline & Inderground wires & OU $-A-14$ \\
\hline & Wiring & () $(1-A-15$ \\
\hline \multirow[t]{7}{*}{ Thermal } & Bunsen burner/hot plates & $O U-B-01$ \\
\hline & Electrical equipment & $\mathrm{OU}-\mathrm{B}-02$ \\
\hline & Furnaces/boilers/heater & $(\mathrm{O})-\mathrm{B}-03$ \\
\hline & Welding torch/arc & $\mathrm{O}(\mathrm{J}-\mathrm{B}-05$ \\
\hline & Dicsel units/fire box/exhaust line & () $) \mathrm{J}-\mathrm{B}-\mathrm{-06}$ \\
\hline & Power tools & $O U-B-09$ \\
\hline & Solar & OCI-B-11 \\
\hline \multirow[t]{7}{*}{ Friction } & Belts & $\mathrm{O}(\mathrm{J}-\mathrm{C}-(\mathrm{O})$ \\
\hline & Bearings & () $-(-0) 2$ \\
\hline & Fans & ()( ) $-(-0) 3$ \\
\hline & Gears & () $(1)-(-0) 4$ \\
\hline & Motors & $O()-C-0) 5$ \\
\hline & l'ower tools & ( $)(1-C-06$ \\
\hline & Other (vohicle brakes) & ()) $10-(0) 7$ \\
\hline \multirow[t]{3}{*}{ Corrosives } & Acids & $(0)-1)-(0)$ \\
\hline & Calstics & $\mathrm{O}(\mathrm{J}-\mathrm{I})-(\mathrm{)} 2$ \\
\hline & Decon solution & $O(j-I)-04$ \\
\hline
\end{tabular}


HNF-SD-SNF-HIE-004 REV 5

Table 14. Standard Industrial Hazards: Outside. (3 sheets)

\begin{tabular}{|c|c|c|}
\hline Hazard category & Iazard type & $\begin{array}{c}\text { Jazard checklist } \\
\text { identification } \\
\text { number }\end{array}$ \\
\hline \multirow[t]{3}{*}{ Kinetic - rotational } & Motors & () $\mathrm{J}-\mathrm{E}-() 2$ \\
\hline & Pumps & () \\
\hline & Shop equipment & ()$(J-E-0) 6$ \\
\hline \multirow[t]{5}{*}{ Kinetic - linear } & Forklifts, dollies, carts & $\mathrm{OU}-\mathrm{F}-02$ \\
\hline & Railroad & () IJ-F-03 \\
\hline & Cranc lorads & ()1)-F-05 \\
\hline & Pressure vesisel blowdown & $(0)-F-() 6$ \\
\hline & ()ther (gas bottles) & $0 \mathrm{~J}-\mathrm{F}-07$ \\
\hline \multirow[t]{12}{*}{ Mass, gravity, height } & Human ellont & $O(\mathrm{~J}-\mathrm{C}-\mathrm{O}-\mathrm{O})$ \\
\hline & Lilts and cranes & $O[\mathrm{~J}-\mathrm{C}-() 3$ \\
\hline & Bucket and ladder & ()[]-(i-04 \\
\hline & Trucks & $O U-\mathrm{G}=05$ \\
\hline & Slings & OU)-G-06 \\
\hline & Hoists & () $[1-(i-0) 7$ \\
\hline & liakis & O $]-(\mathrm{i}-09$ \\
\hline & Sicaffold and ladders & () $1 \mathrm{~J}-(\mathrm{i}-10$ \\
\hline & l'its and excavations & () $(J-(i-1)$ \\
\hline & Dilevated doors & () $\mathrm{J}-\mathrm{c}-12$ \\
\hline & Vexiels & () $1 \mathrm{~J}-(\mathrm{i}-13$ \\
\hline & (Other (roof) & () 1$)-(\mathrm{G}-14$ \\
\hline \multirow[t]{2}{*}{ Pressure - volume } & (ias bottles & () $\mathrm{U}-\mathrm{H}-05$ \\
\hline & ['ressure vessels & () $\mathrm{J}-\mathrm{H}-0) 6$ \\
\hline Explosives/pyrophorics & Gases, others & ()$(\mathrm{J}-. \mathrm{I}-(0)$ \\
\hline \multirow[t]{2}{*}{ Flammable materials } & Buildings and contents & $0 U-\mathrm{L}-(08$ \\
\hline & Hydrogen & ()$[J-1,-11$ \\
\hline \multirow[t]{7}{*}{ Hazardous materials } & Asphyxiants & $(\mathrm{OU}-\mathrm{M}-02$ \\
\hline & Biologicals & ()$(J-M-0) 3$ \\
\hline & Carcinogens & () (J-M-O) \\
\hline & Corrosives & () $1-M-05$ \\
\hline & Oxidizers & ()$[J-M-06$ \\
\hline & honics & () $1 \mathrm{~J}-\mathrm{M}-07$ \\
\hline & louvy metals & ()$(\mathrm{J}-\mathrm{M}-() \mathrm{S}$ \\
\hline
\end{tabular}


HNF-SD-SNF-HIE-004 REV 5

Table 14. Standard Industrial Hazards: Outside. (3 sheets)

\begin{tabular}{|l|l|l|}
\hline \multicolumn{1}{|c|}{ Hazard category } & \multicolumn{1}{|c|}{ Hazard type } & $\begin{array}{c}\text { Hazard checklist } \\
\text { identification } \\
\text { number }\end{array}$ \\
\hline \multirow{2}{*}{ Ionizing radiation sources } & Radiography e(puipment & ()$(J-\mathrm{N}-() 2$ \\
\cline { 2 - 4 } & Radioactive sources & $(\mathrm{U})-\mathrm{N}-() 4$ \\
\hline $\begin{array}{l}\text { Vehicles in motion } \\
\text { (extermal to facility) }\end{array}$ & Train & $(\mathrm{J}-\mathrm{O}-() 3$ \\
\hline
\end{tabular}

*Hazard checklist identification numbers $X X-Y$ \#\# represent a specific line item on a harzardous material/energy source checklist (see Table 2) where:

$\mathrm{XX}=$ facility area.

$\mathrm{Y}=$ hazard type

$\#$ \# checklist designator. 
HNF-SD-SNF-HIE-004 REV 5

ATTACHMENT 1

COLD VACUUM DRYING FACILITY HAZARD

ANALYSIS TEAM MEMBERS 
HNF-SD-SNF-HIE-004 REV 5

This page intentionally left blank. 


\section{ATTACHMENT 1 \\ COLD VACUUM DRYING FACILITY HAZARD ANALYSIS TEAM MEMBERS}

The key members of the Cold Vacuum Drying Facility Hazards Analysis brought to the study the following experience.

\section{Walter Alaconis}

B.S., General Science. Nearly 27 years of diversified nuclear safety and operations experience in the military, commercial, and U.S. Department of Energy (DOE) environments. Obtained registration with the National Registry of Radiation Protection Technologists in 1982. Over 16 years at the Hanford Site supporting major facility modifications and new facility design projects. Co-author of the Process Facility Modification Project Preliminary Safety Analysis Report. Managed the development of the Hanford Site Quality Training and Resource Center Root Cause Analysis Training Program and the Accident/Event Trending Program. Managed the Nuclear Engineering/Safety Data Management Unit for 4 years. Technical advisor to the Liquid Effluent Services Program at the Hanford Site and the Environmental Restoration Programs at the Hanford Site and DOE-Headquarters. Facilities supported at the Hanford Site include the tank farms (east), PUREX, B Plant, Plutonium Finishing Plant, Treated Effluent Disposal Facility, and Effluent Treatment Facility.

\section{JoAnn Brehm}

B.S., Biology, Mechanical Engineering. Twenty-two years experience in the nuclear industry, including sodium test reactor startup and operations, major DOE and international decontamination and decommissioning projects, and technology transfer. Six years direct experience in providing project management and preparing nuclear safety analysis documents for DOE facilities, including the Shippingport Station Decommissioning Project, Spent Nuclear Fuel Project, and the Waste Encapsulation and Storage Facility.

\section{Ralph D. Crowe}

M.S., Nuclear Engineering and Engineering Management. Over 20 years experience in the nuclear industry performing calculations using multidimensional time-dependent neutron kinetics and thermal hydraulic codes. Six years experience performing safety analysis within the DOE environment for a number of facilities, including high-level waste tanks, Plutonium Finishing Plant, and spent fuel storage. 
HNF-SD-SNF-HIE-004 REV 5

\section{John J. Irwin}

B.S. Degree in Mechanical Engineering and in Aeronautical Engineering, Masters of Science Program in Mechanical Engineering. Principal Engineer at the Numatec Hanford Corporation, with 24 years experience. Formerly with Space Division of the Rockwell Corporation as a member of the technical staff. Worked as a mechanical engineer on the Space Shuttle Program, Fast Flux Test Facility (FFTF) Reactor, Fusion Materials Irradiation Test Facility, SP100 Space Reactor Test Facility, and the K Basin Spent Nuclear Fuel Project.

\section{Dwight E. Krahn}

B.S., General Engineering, field of specialty in Operations Research. Eight years experience in engineering and safety analysis activities. Training includes safety analysis development, root cause analysis, and risk assessment. Most recent work has been in the area of Technical Safety Requirements for the Waste Encapsulation and Storage Facility and the tank farms.

\section{Curt Miska}

B. S., Chemical Engineering. Seventeen years experience with Westinghouse Hanford Company/Rockwell Hanford Operations. Operations supervisor for PUREX Head End, PUREX Solvent Extraction, PUREX Plutonium Processing, and Uranium Conversion Facility (U03 Plant). Lead/cognizant process engineer for PUREX Solvent Extraction, PUREX Plutonium Processing, and B Plant cesium ion exchange systems. Currently an engineer for the Spent Nuclear Fuel Project. Developed preconceptual design concepts for potential fuel stabilization facilities. Provided technical input to DOE Spent Nuclear Fuel Programmatic Environmental Impact Statement for $\mathrm{N}$ Reactor fuel stabilization, including developing bases for information such as construction and operating resources and personnel required, and routine and accidental radiological and nonradiological releases. Provided major input for and coordinated completion of Dry Storage Technical Evaluation, including development of preliminary processing scheme, material balance, cycle time, and life-cycle cost estimates.

\section{Paul Patterson}

Senior Reactor Operator (SRO), Hanford N-Reactor. Seventeen years experience in nuclear power plant and facility operations, training, safety and procedure development. As an SRO responsibilities included maintaining reactor safety during all modes of operation from the reactor control room. A certified DOE technical trainer and oral board examiner. Instructed reactor operator and senior reactor operator candidates and facility management in reactor process operations, heat transfer and fluid flow, reactor physics fundamentals, and accident analysis and safety basis. As a consultant, facilitator, and writer supporting various Hanford Site and Idaho National Engineering Laboratory projects over the past 10 years, led safety document and 
requirements processes and hazard analyses sessions; participated in operational readiness reviews; designed and developed training and qualification programs; presented specialized training programs; facilitated specialized group processes; and supported process and facility operating procedure development during final stages of engineering and facility start-up.

\section{Carole Pili-Vincens}

Graduate Engineer, Environment, Health and Safety; Technological Hazards Management; Reliability and Maintainability Studies. Six years experience in the nuclear industry performing safety analyses, managing a safety group, and defining safety analysis methods for French nuclear facilities (including high-level waste treatment and storage). Specialist in pyrophoricity reaction risks and environmental analyses. Two years experience performing safety and environmental analyses and assessments as a consultant for industrial facilities (chemical and oil plants).

\section{Richard Whitehurst}

Over 27 years experience in nuclear-related instrumentation and controls, operations, and project management. Design/project lead engineer for computer-controlled processes, including the 300 Area Treated Effluent Disposal Facility and the K East Basin monitoring and control systems. Cognizant engineer at the FFTF with direct responsibilities for a number of process systems, including safety-class systems such as Seismic Monitoring, Safe Shutdown Monitoring, and Emergency Dump Heater Exchanger Control System. Experience in operations with both the FFTF and the U.S. Nuclear Navy. Performed duties as test director and test engineer at K Basins, 300 Area Treated Effluent Disposal Facility, and the FFTF. Involved in safety equipment and procedures since 1979 at FFTF. 
HNF-SD-SNF-HIE-004 REV 5

This page intentionally left blank. 
HNF-SD-SNF-HIE-004 REV 5

ATTACHMENT 2

COLD VACUUM DRYING FACILITY HAZARD ANALYSIS 
HNF-SD-SNF-HIE-004 REV 5

This page intentionally left blank. 
HNF-SD-SNF-HIE-004 REV 5

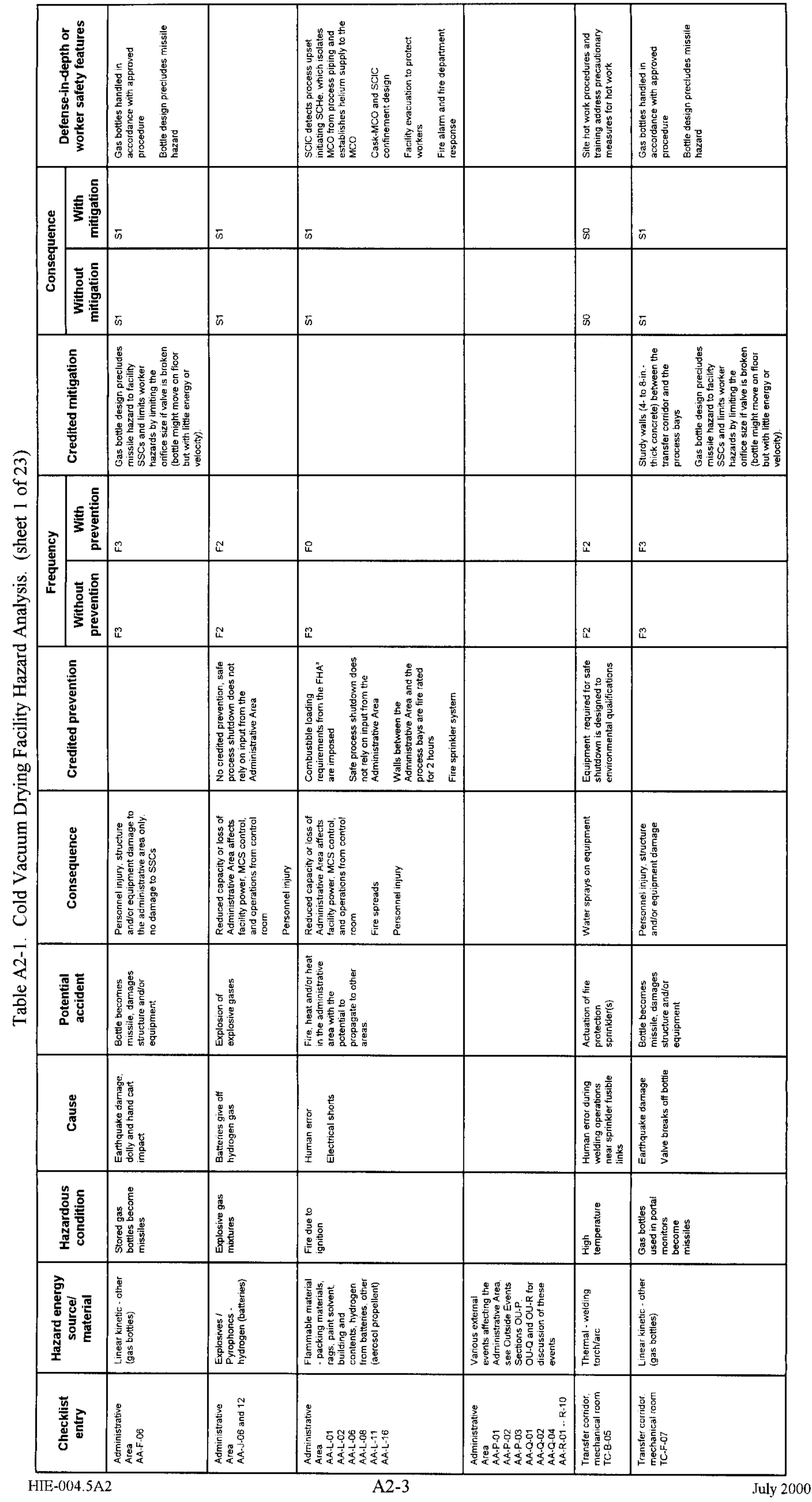


HNF-SD-SNF-HIE-004 REV 5

\begin{tabular}{|c|c|c|c|c|c|c|c|}
\hline 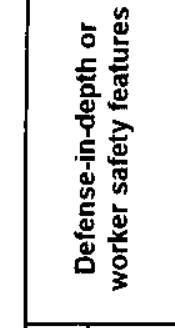 & 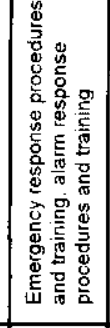 & & 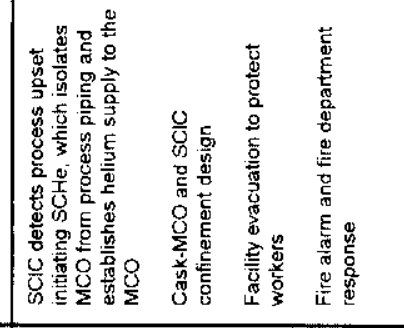 & & 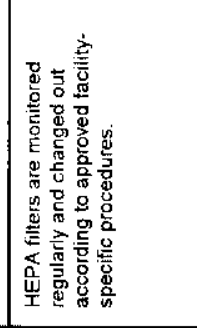 & & 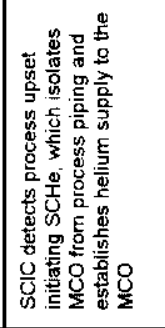 \\
\hline 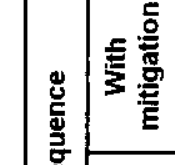 & $\overline{5}$ & & $\overline{5}$ & & $\bar{n}$ & & in \\
\hline 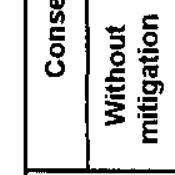 & $\approx$ & & $\overline{\bar{n}}$ & $\bar{n}$ & $\overline{\bar{n}}$ & & $\approx$ \\
\hline 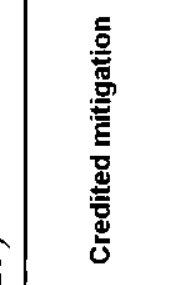 & 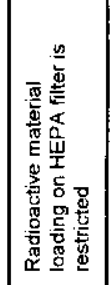 & & & & & & 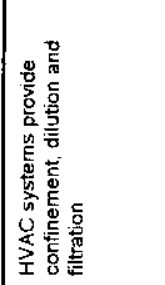 \\
\hline 密 & 포․ & & i & & 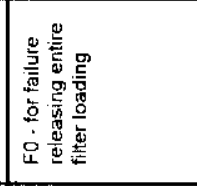 & & 인 \\
\hline 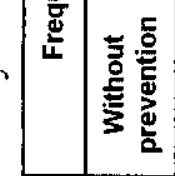 & is & i & $\mathbb{Z}$ & జ & 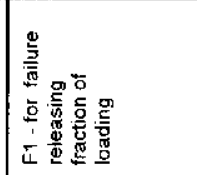 & & \\
\hline 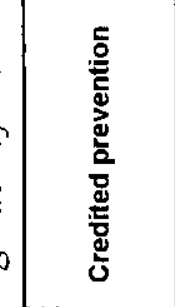 & 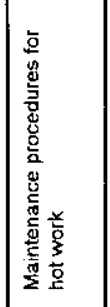 & 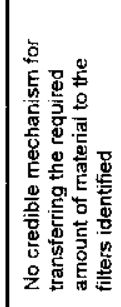 & 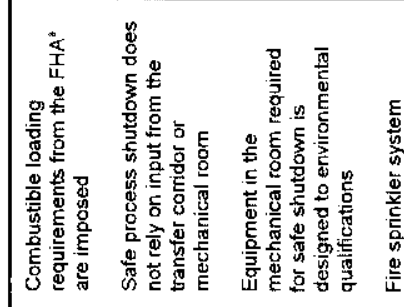 & 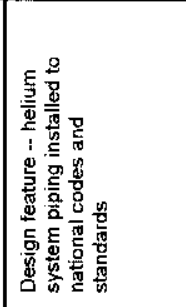 & 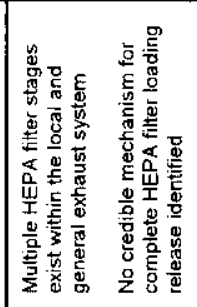 & & 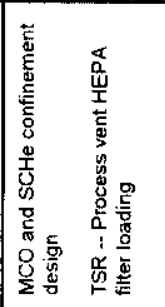 \\
\hline 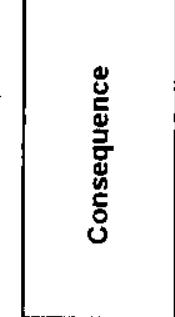 & 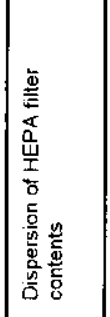 & 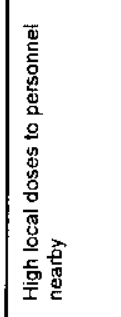 & 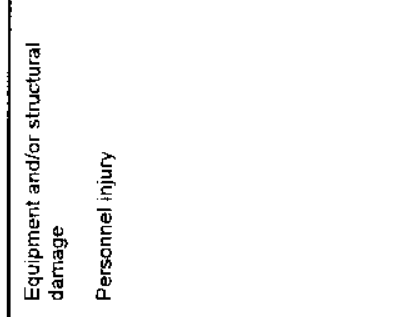 & & 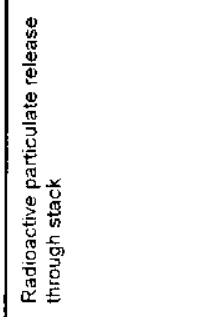 & & 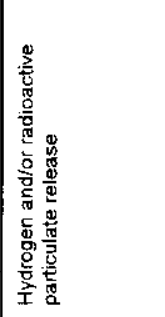 \\
\hline 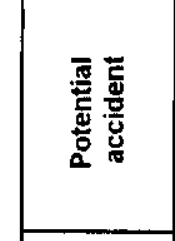 & 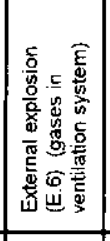 & 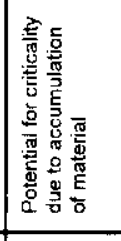 & 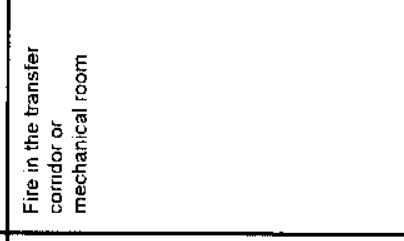 & & 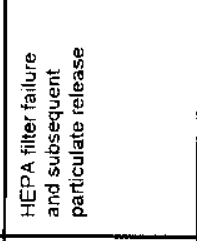 & & 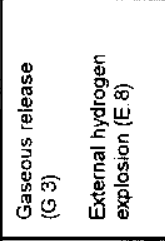 \\
\hline 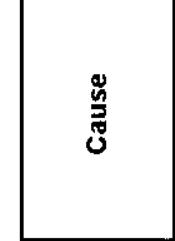 & 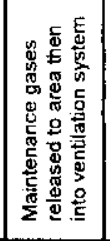 & 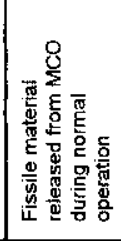 & 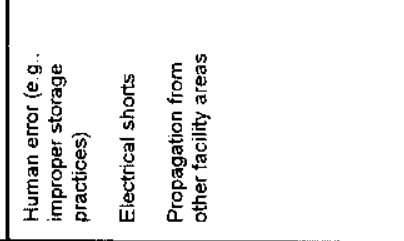 & 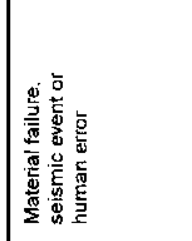 & 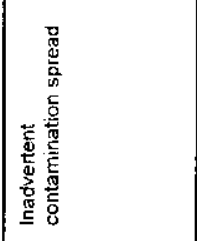 & & 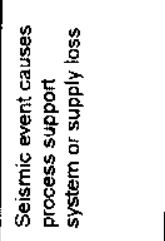 \\
\hline 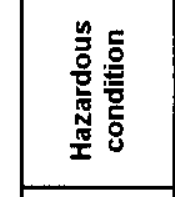 & 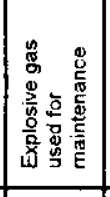 & 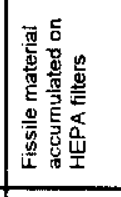 & 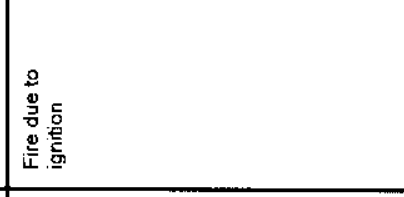 & 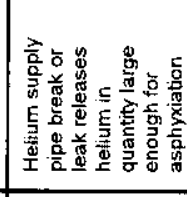 & 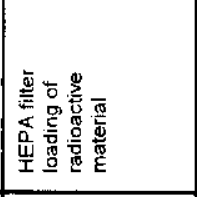 & & 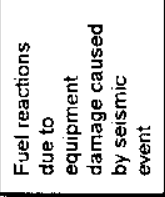 \\
\hline 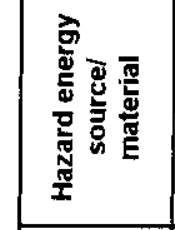 & 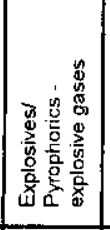 & 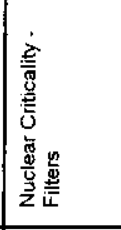 & 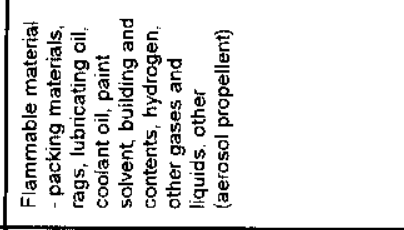 & 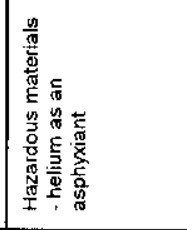 & 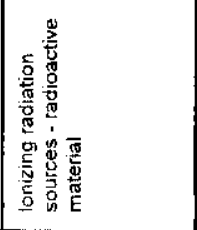 & 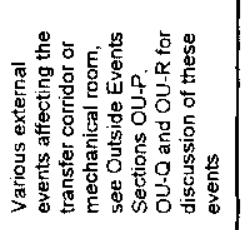 & 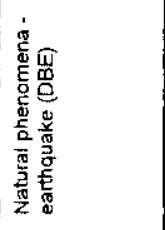 \\
\hline 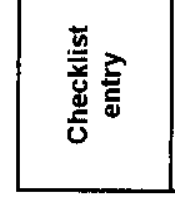 & 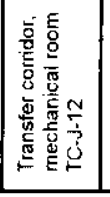 & 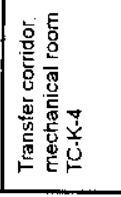 & 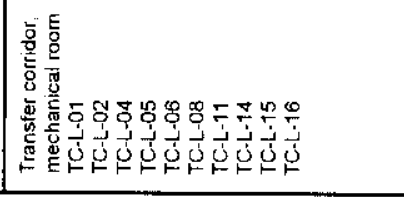 & 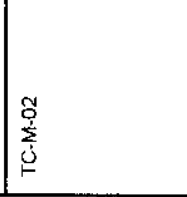 & 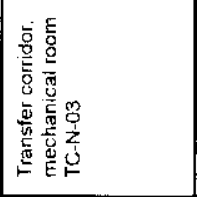 & 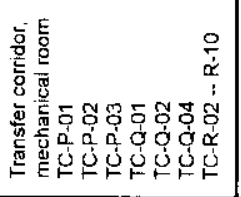 & 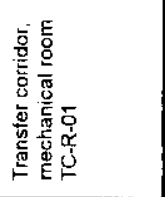 \\
\hline
\end{tabular}


HNF-SD-SNF-HIE-004 REV 5

\begin{tabular}{|c|c|c|c|c|c|}
\hline 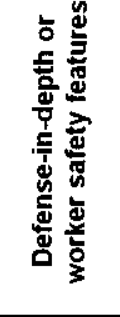 & & 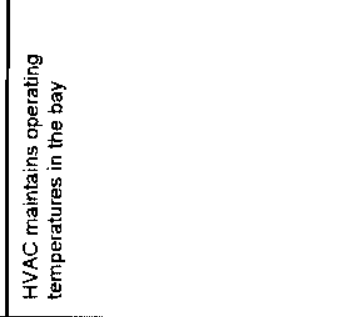 & & 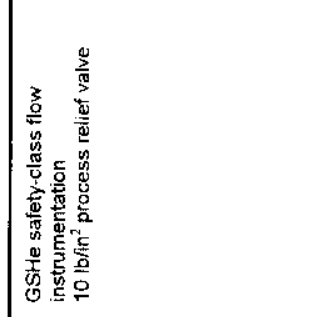 & 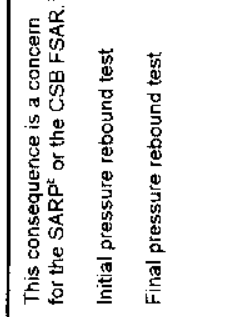 \\
\hline 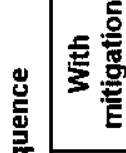 & $\overline{5}$ & $\overline{\bar{n}}$ & $\bar{i}$ & $\bar{\zeta}$ & $\bar{s}$ \\
\hline 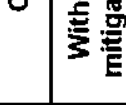 & $\approx$ & $\mathscr{B}$ & $\tilde{n}$ & 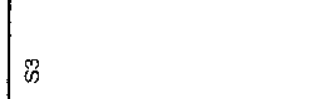 & $\approx$ \\
\hline 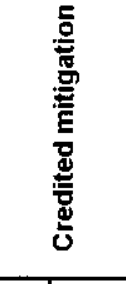 & 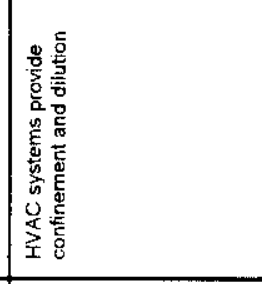 & 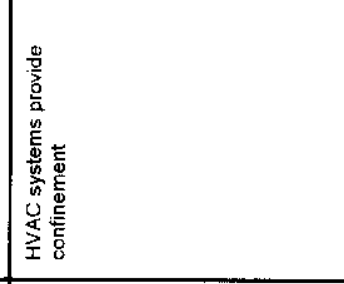 & & 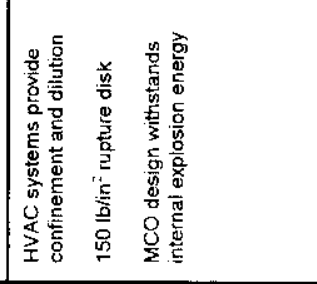 & 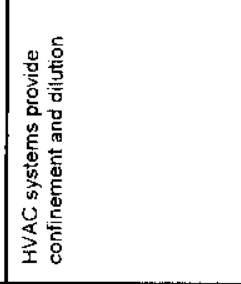 \\
\hline 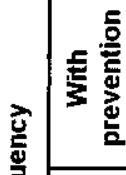 & : & i & i & i & $E$ \\
\hline 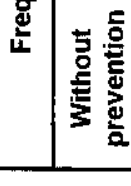 & is & $\ddot{2}$ & $\mathbb{2}$ & 2 & ¿ \\
\hline 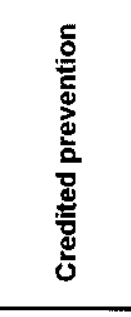 & 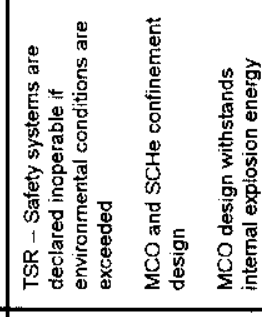 & 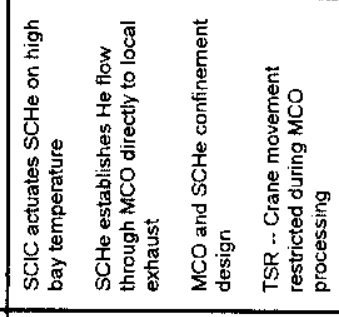 & 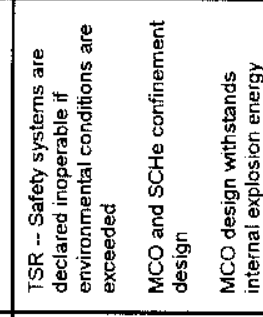 & 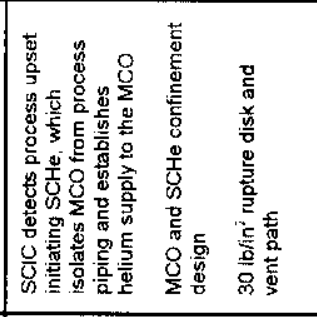 & 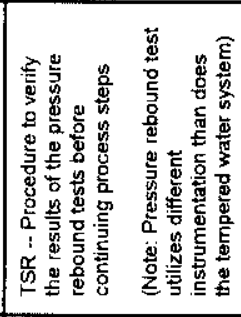 \\
\hline 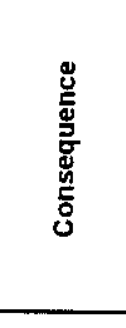 & 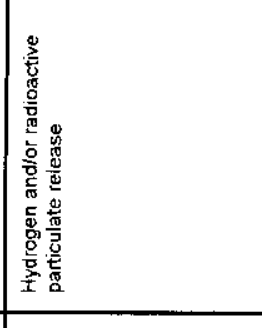 & 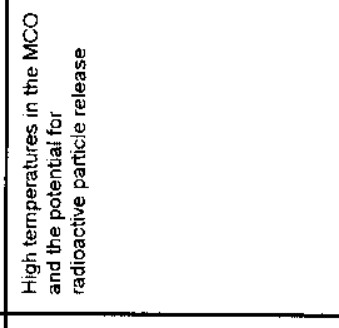 & & 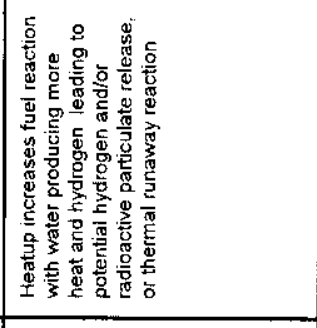 & 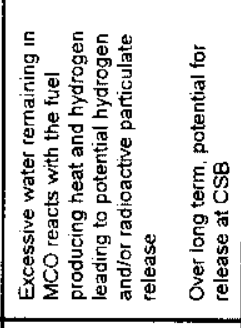 \\
\hline 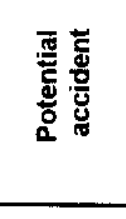 & 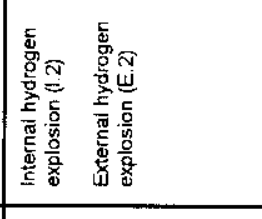 & 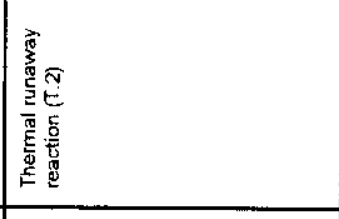 & 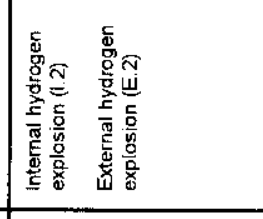 & 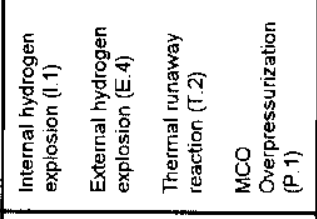 & 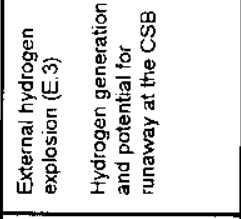 \\
\hline 岁 & 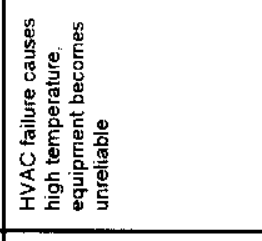 & 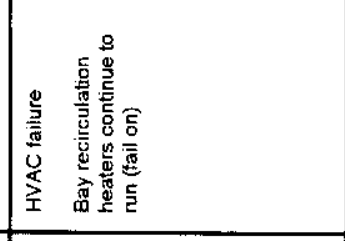 & 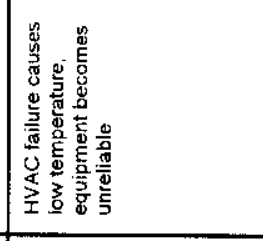 & 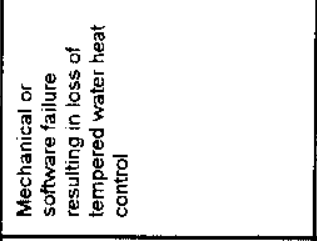 & 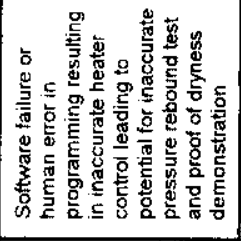 \\
\hline 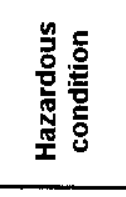 & 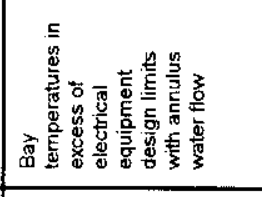 & 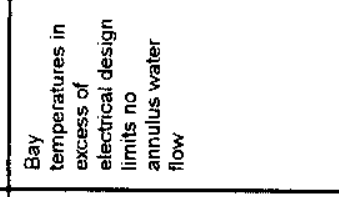 & 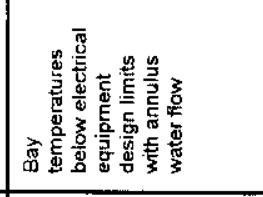 & 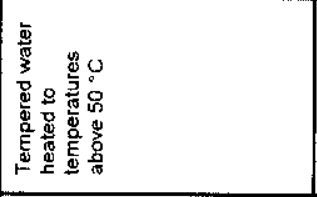 & 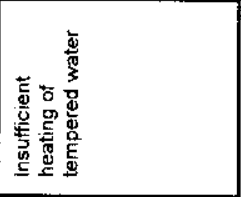 \\
\hline 总 & 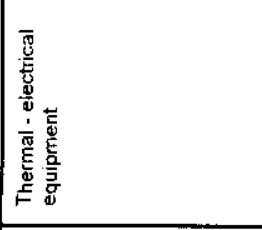 & 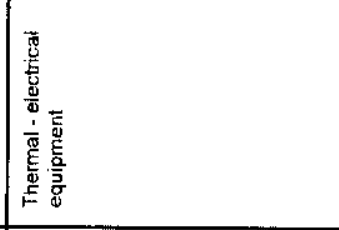 & 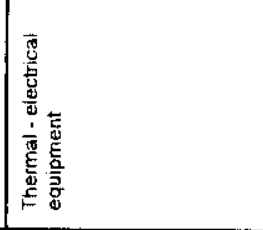 & 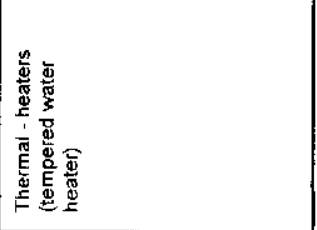 & 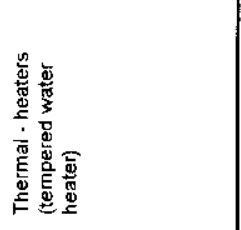 \\
\hline 蒿 & 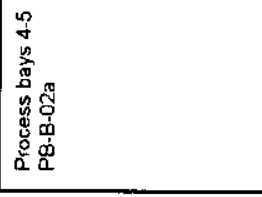 & 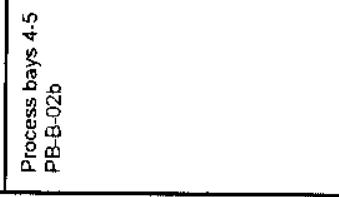 & 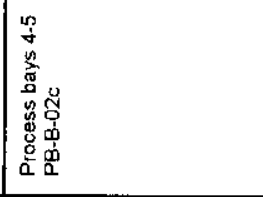 & 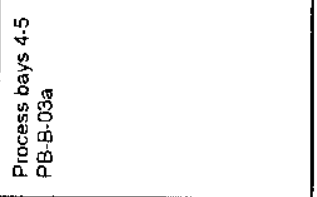 & 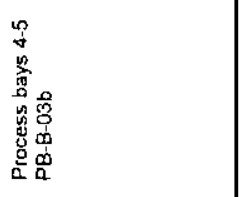 \\
\hline
\end{tabular}


HNF-SD-SNF-HIE-004 REV 5

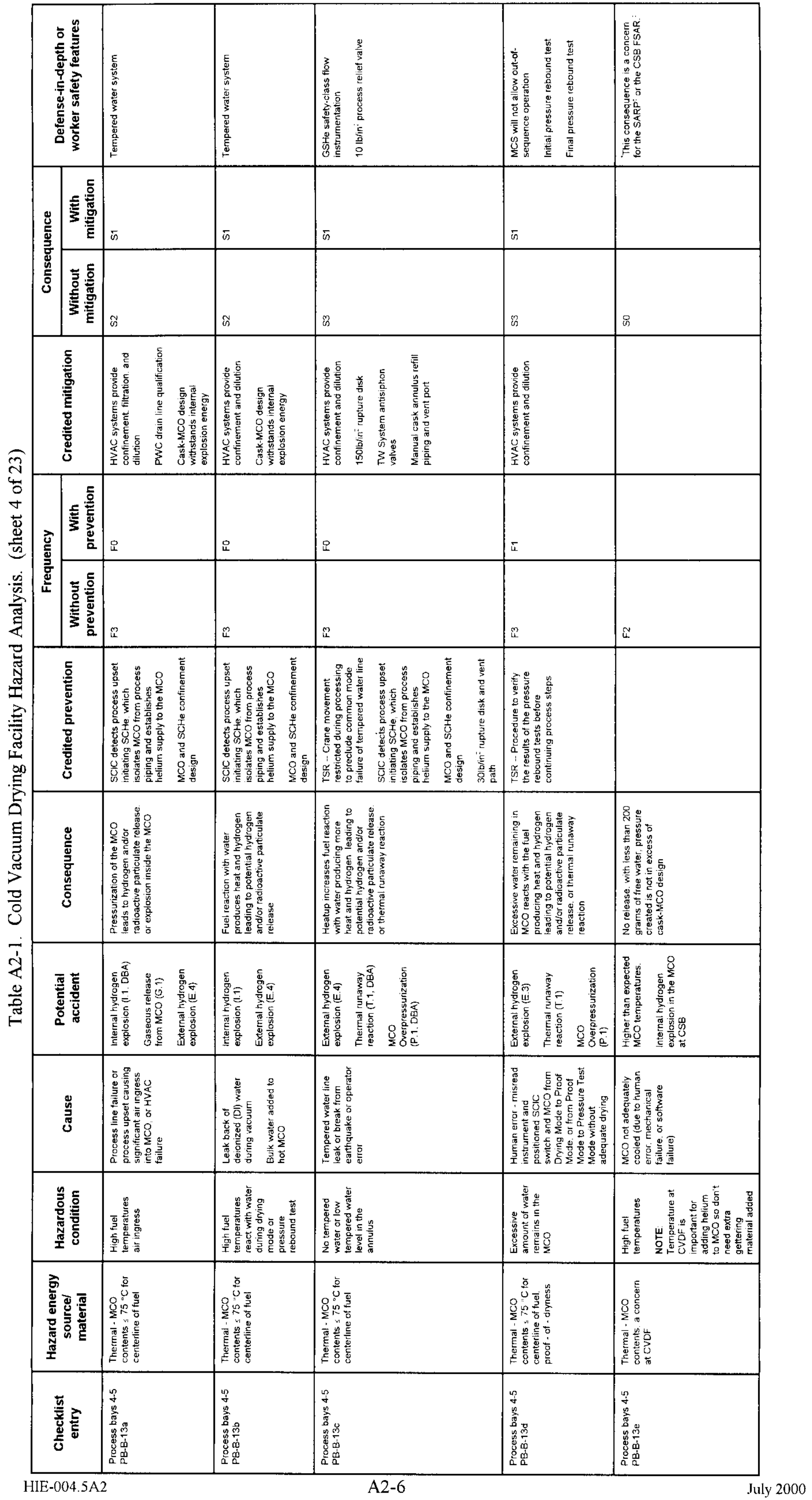


HNF-SD-SNF-HIE-004 REV 5

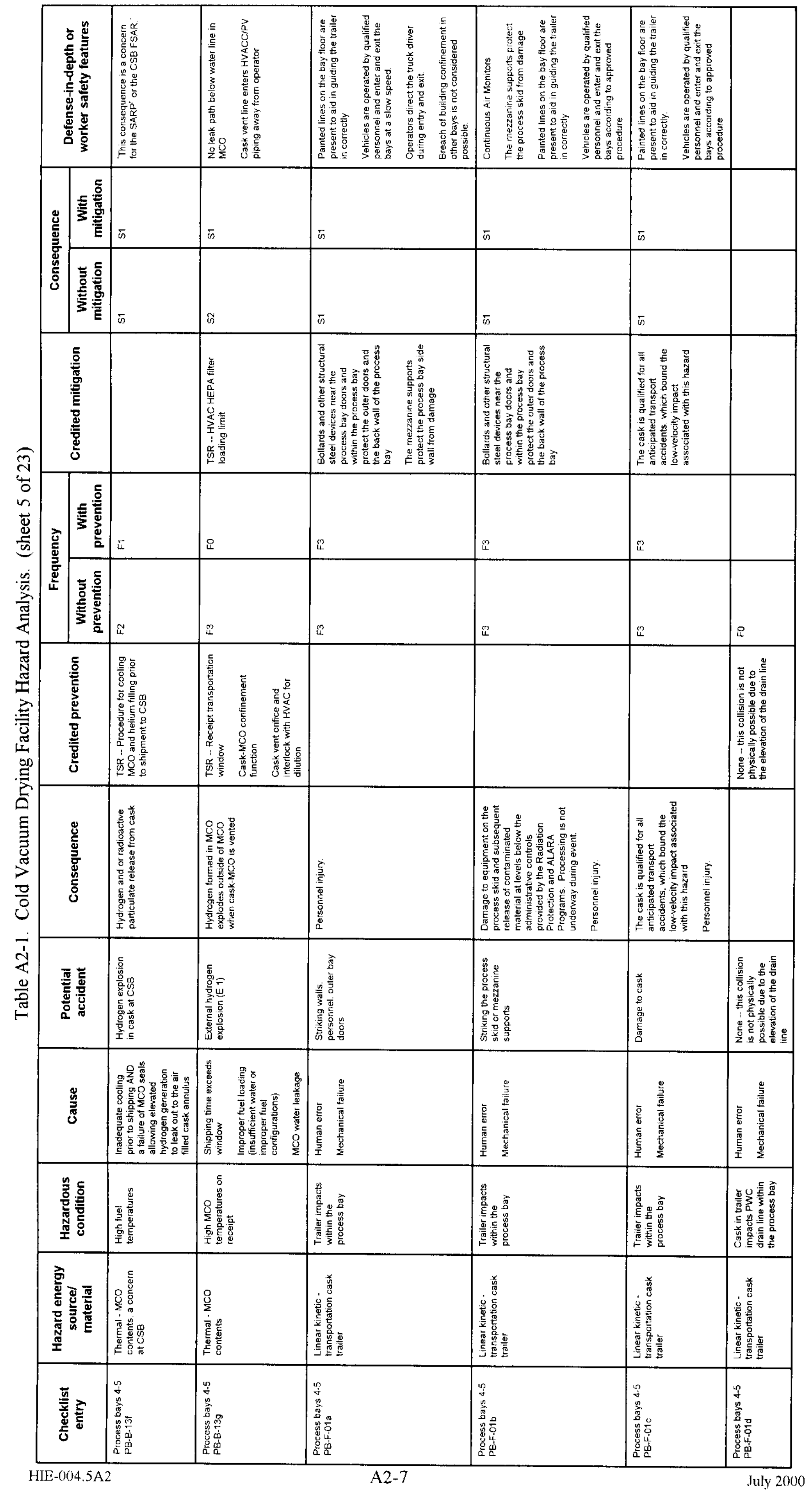


HNI-SD-SNF-HIE-(004 REV 5

\begin{tabular}{|c|c|c|c|c|c|}
\hline & 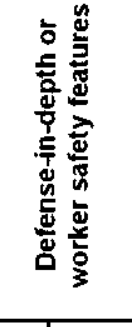 & 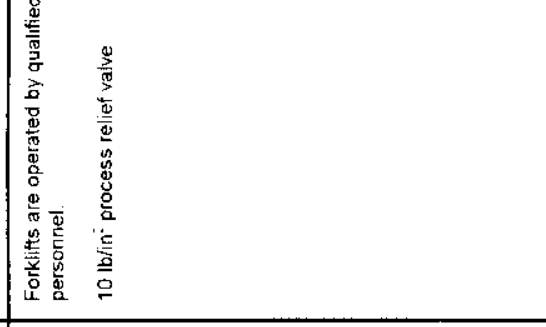 & 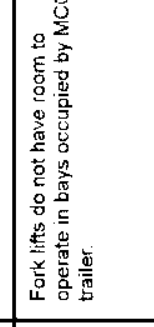 & 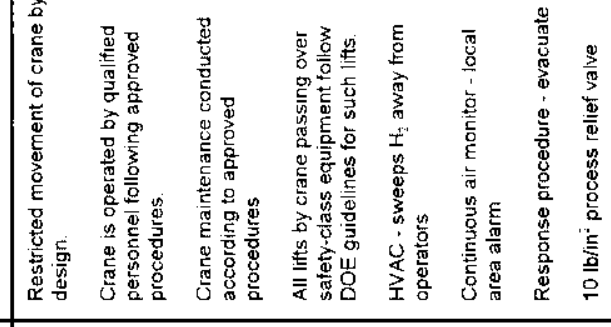 & 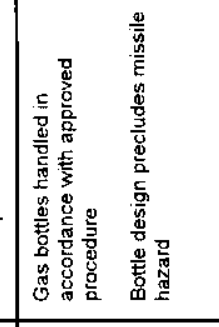 \\
\hline & 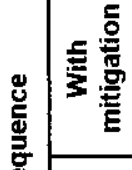 & $\overline{5}$ & & $\overline{5}$ & $\overline{5}$ \\
\hline & 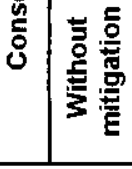 & 8 & & 83 & $\bar{s}$ \\
\hline & 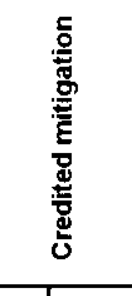 & 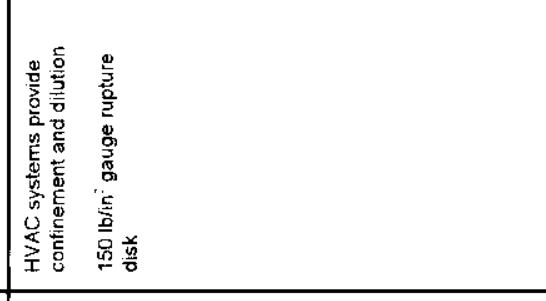 & & 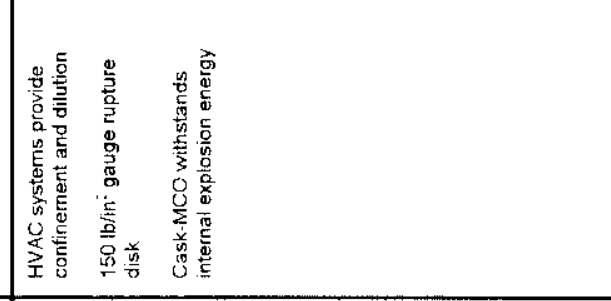 & 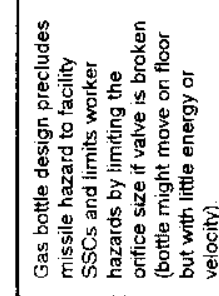 \\
\hline & 毵 & i & & is & 2 \\
\hline & 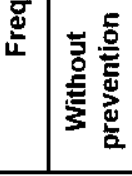 & 8 & : & $\mathscr{I}$ & : \\
\hline & 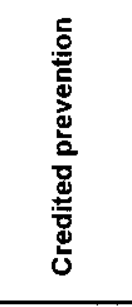 & 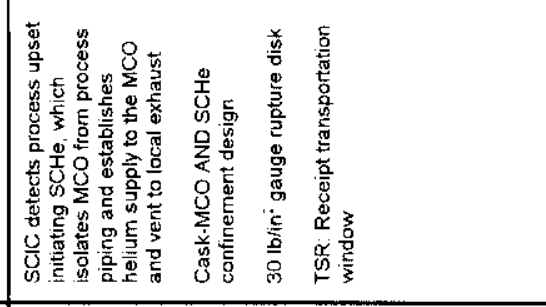 & 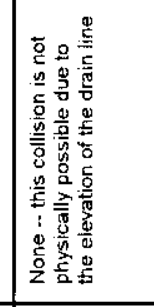 & 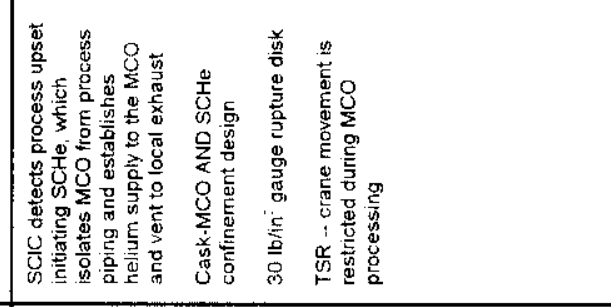 & \\
\hline & 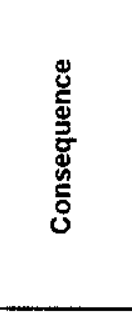 & 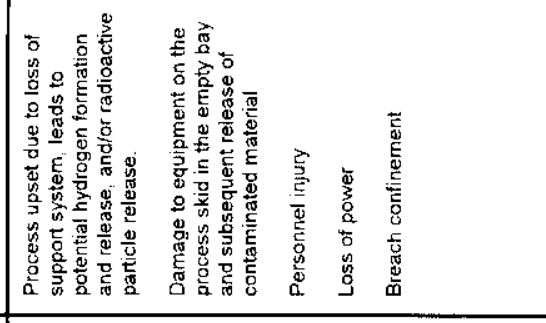 & & 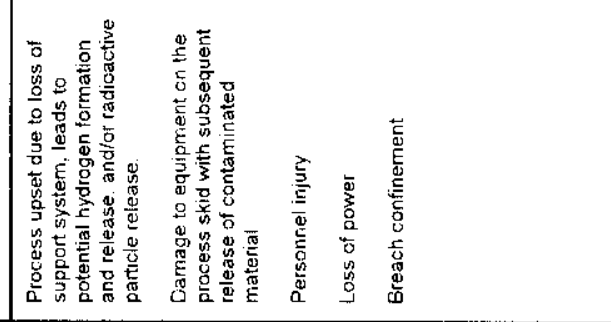 & 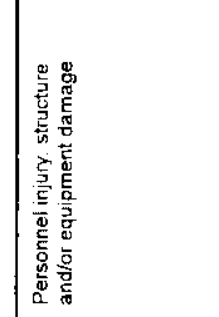 \\
\hline & 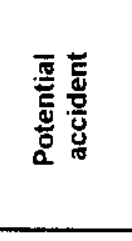 & 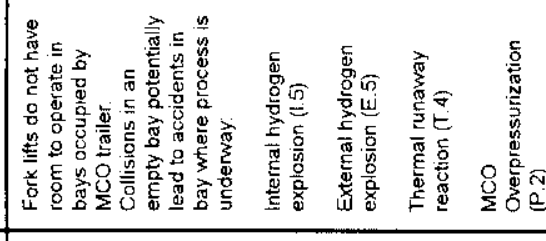 & 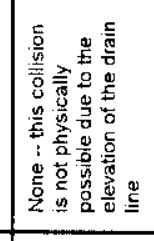 & 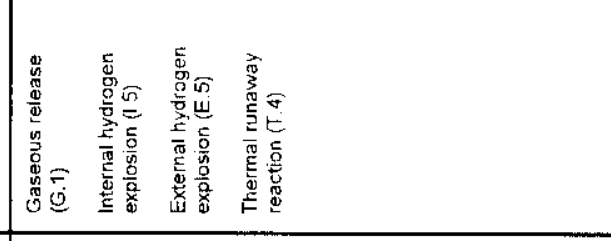 & 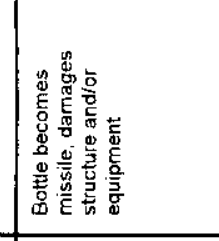 \\
\hline & 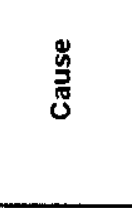 & 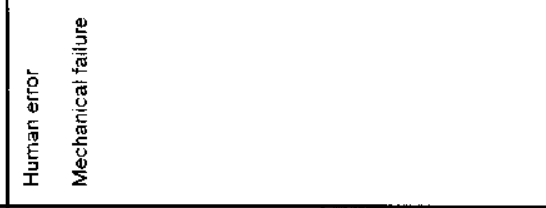 & 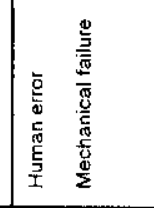 & & 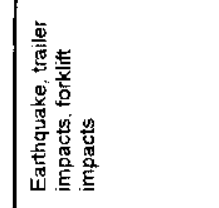 \\
\hline & 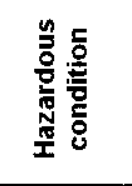 & 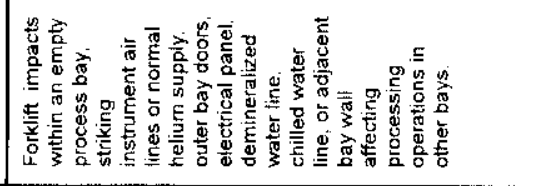 & 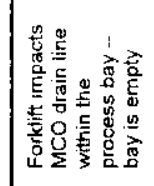 & 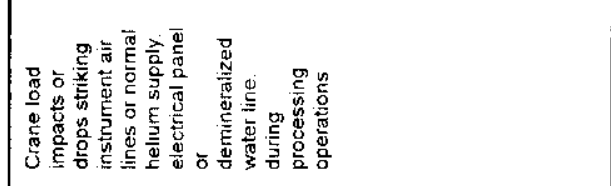 & 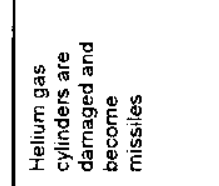 \\
\hline & 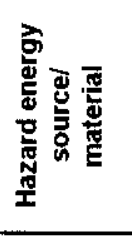 & 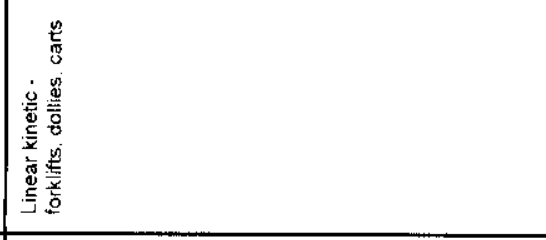 & 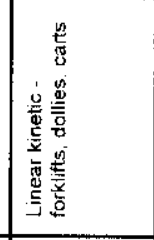 & 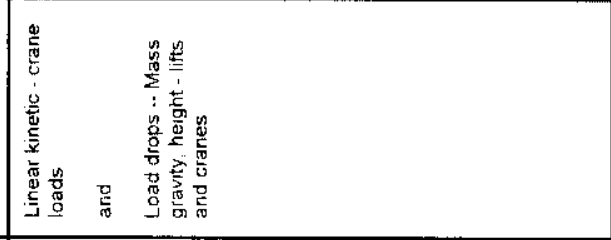 & 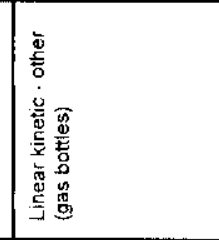 \\
\hline & 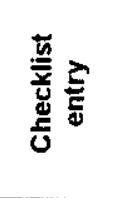 & 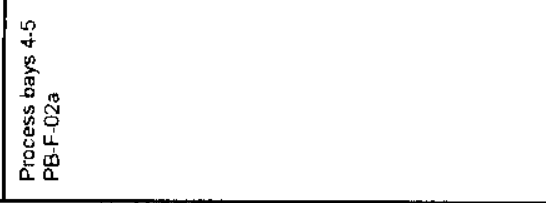 & 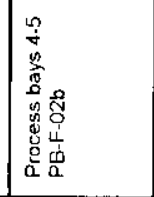 & 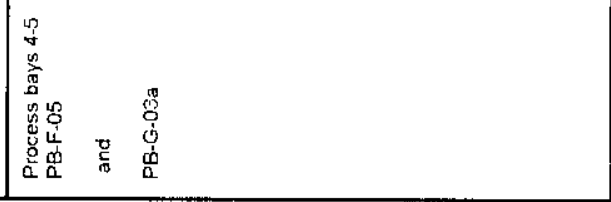 & 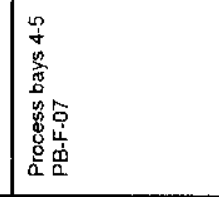 \\
\hline
\end{tabular}


HNF-SD-SNF-HIE-004 REV 5

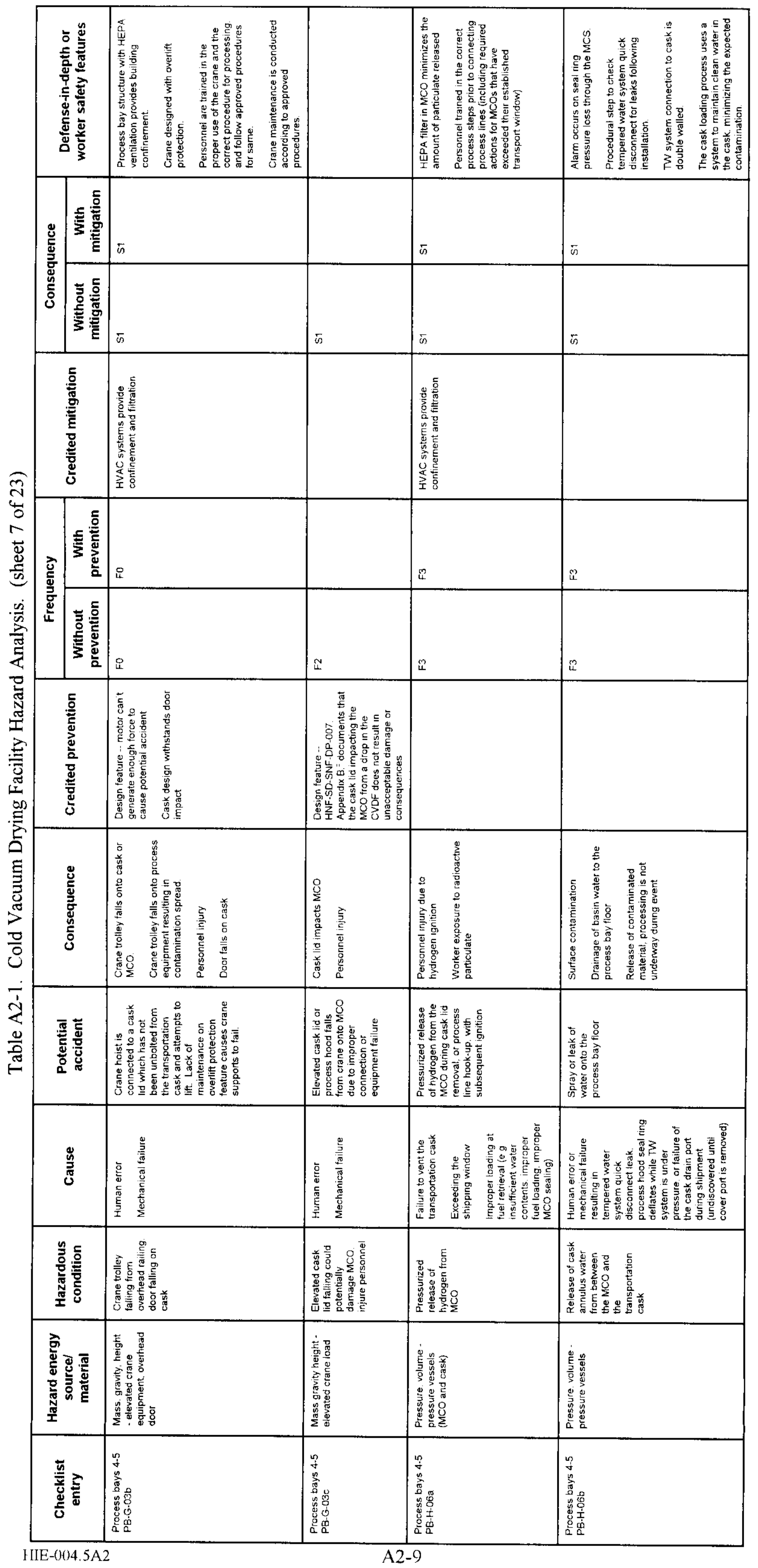


HNF-SD-SNF-HIE-004 REV 5

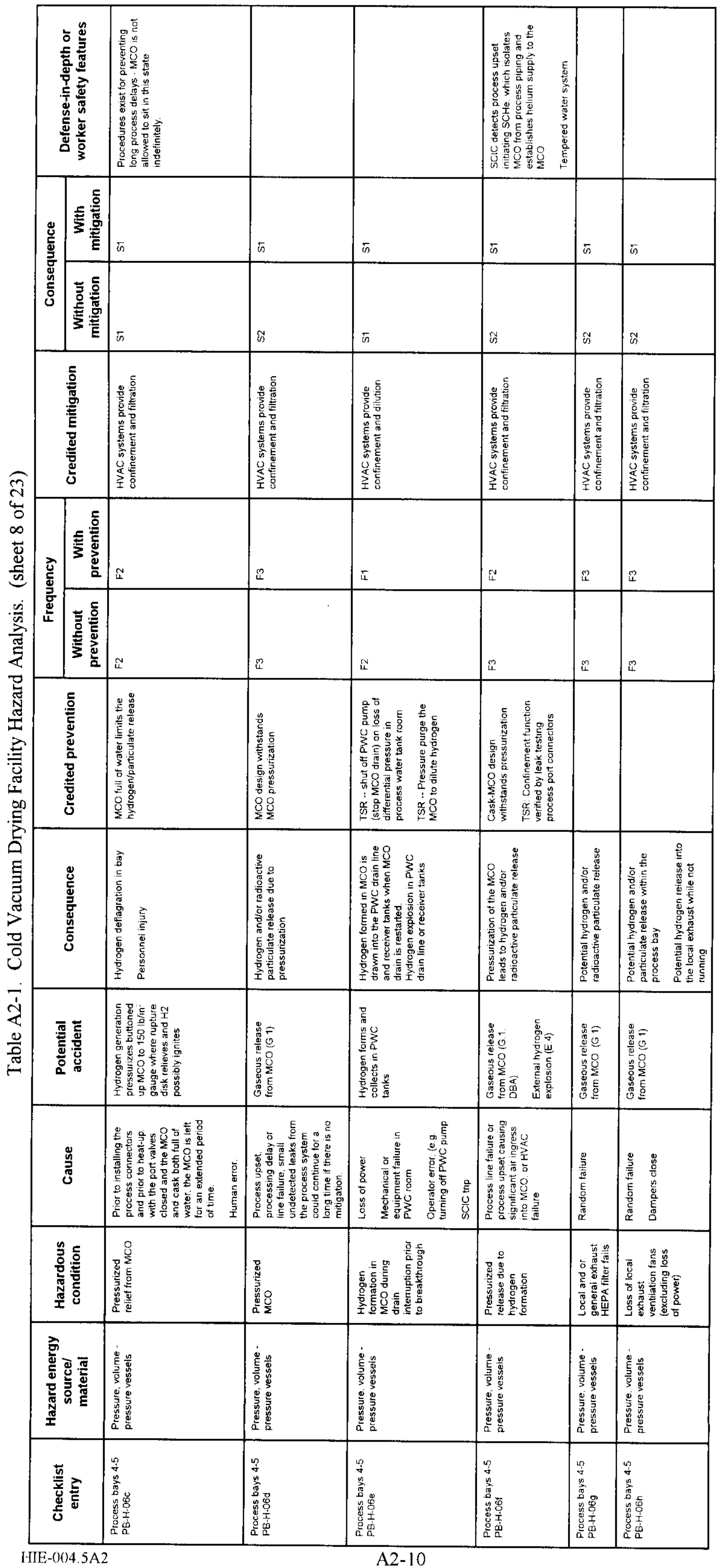


HNF-SD-SNF-HIE-004 REV 5

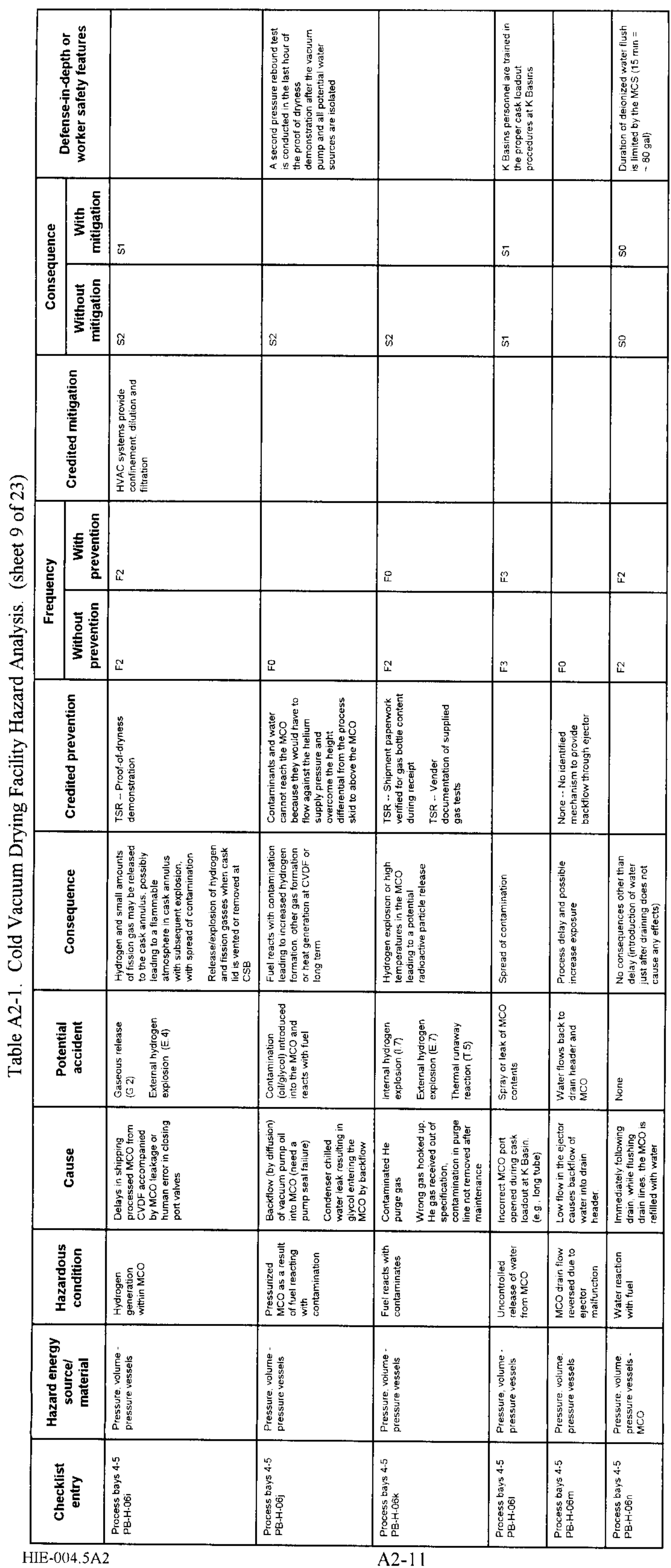


HNF-SD-SNF-HIE-004 REV 5

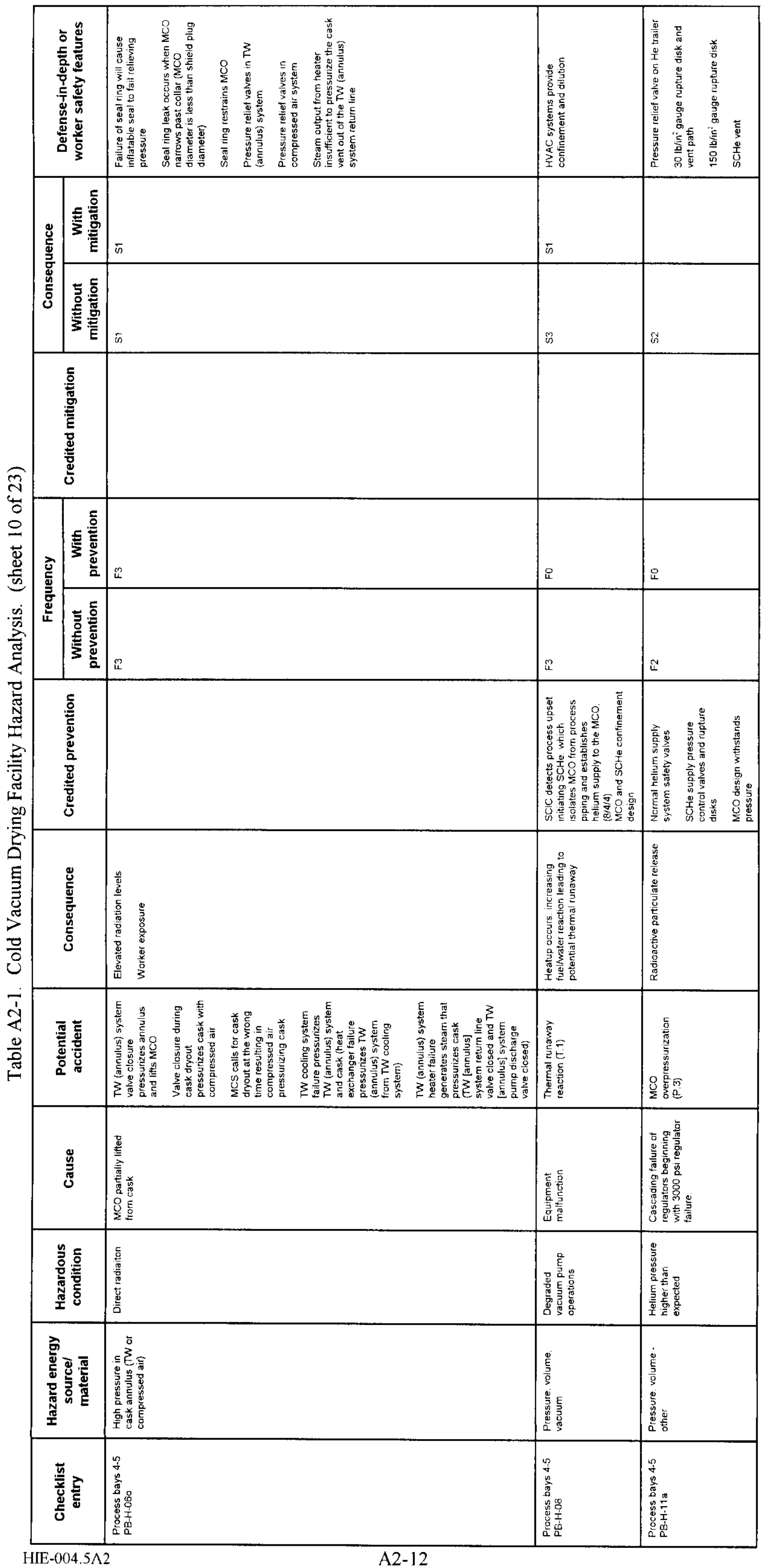


HNF-SD-SNF-HIE-004 REV 5

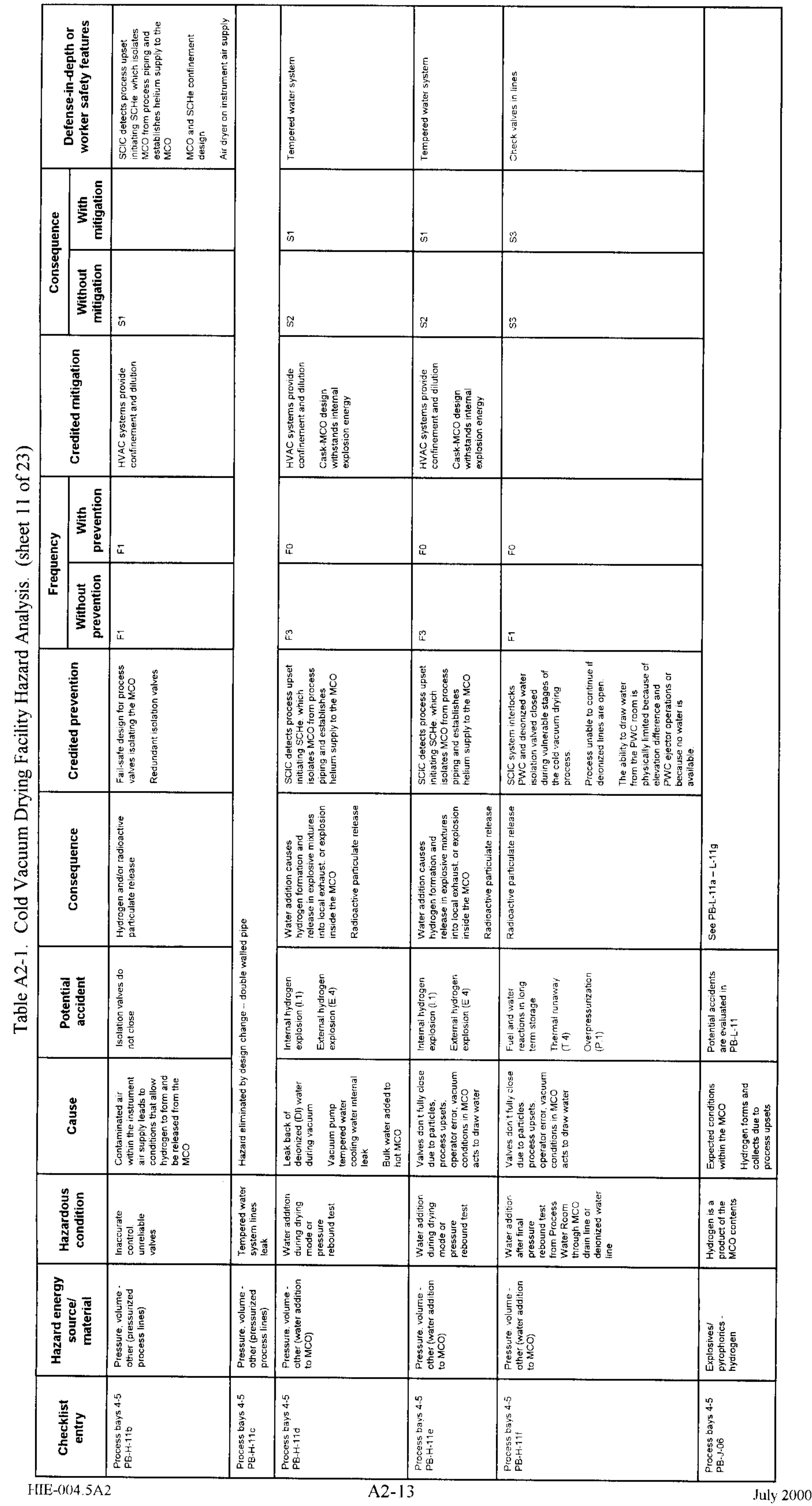


HNF-SD-SNF-HIE-004 REV 5

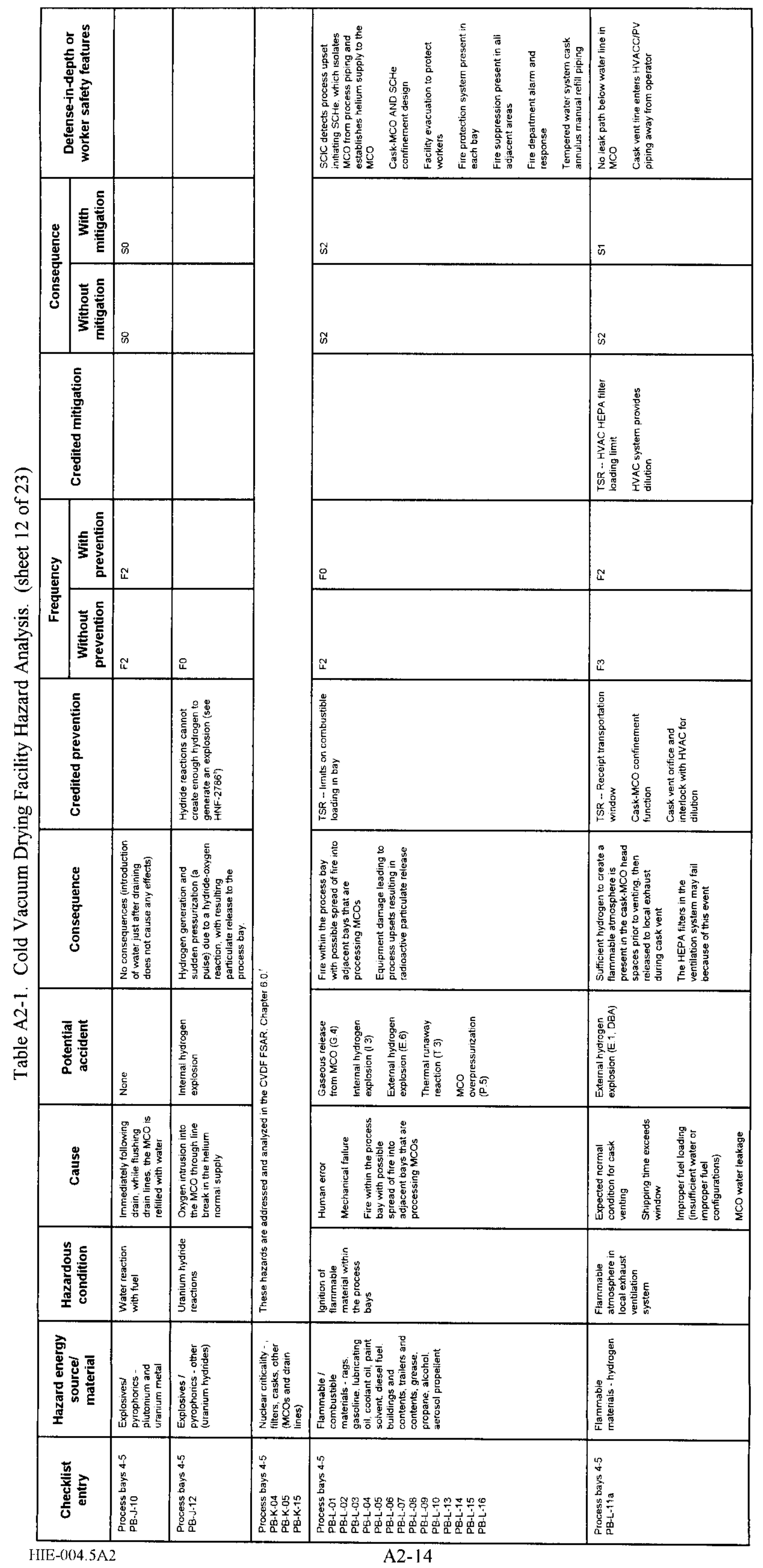


HNF-SD-SNF-HIE-004 REV 5

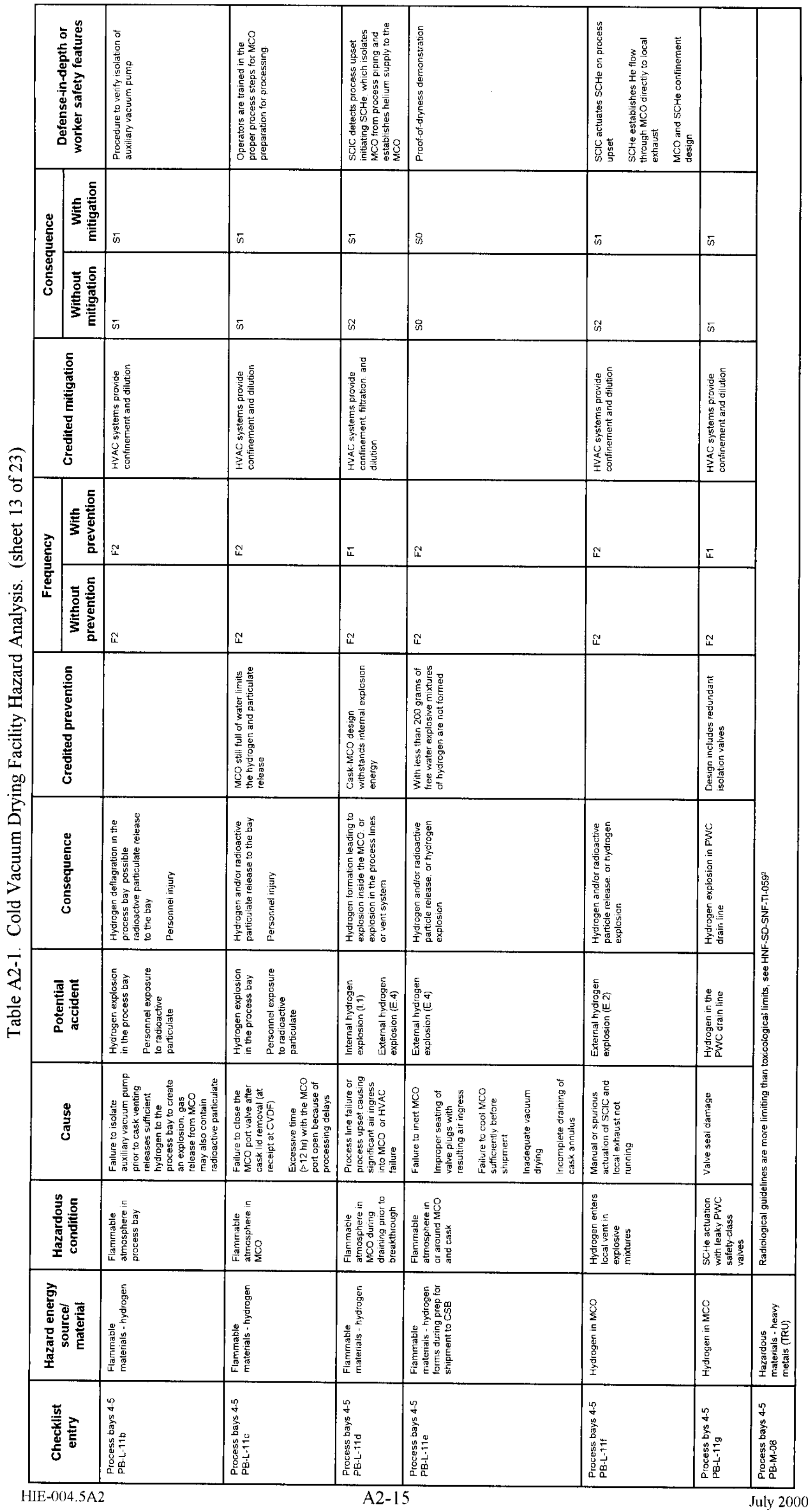


HNF-SD-SNF-HIE-004 REV 5

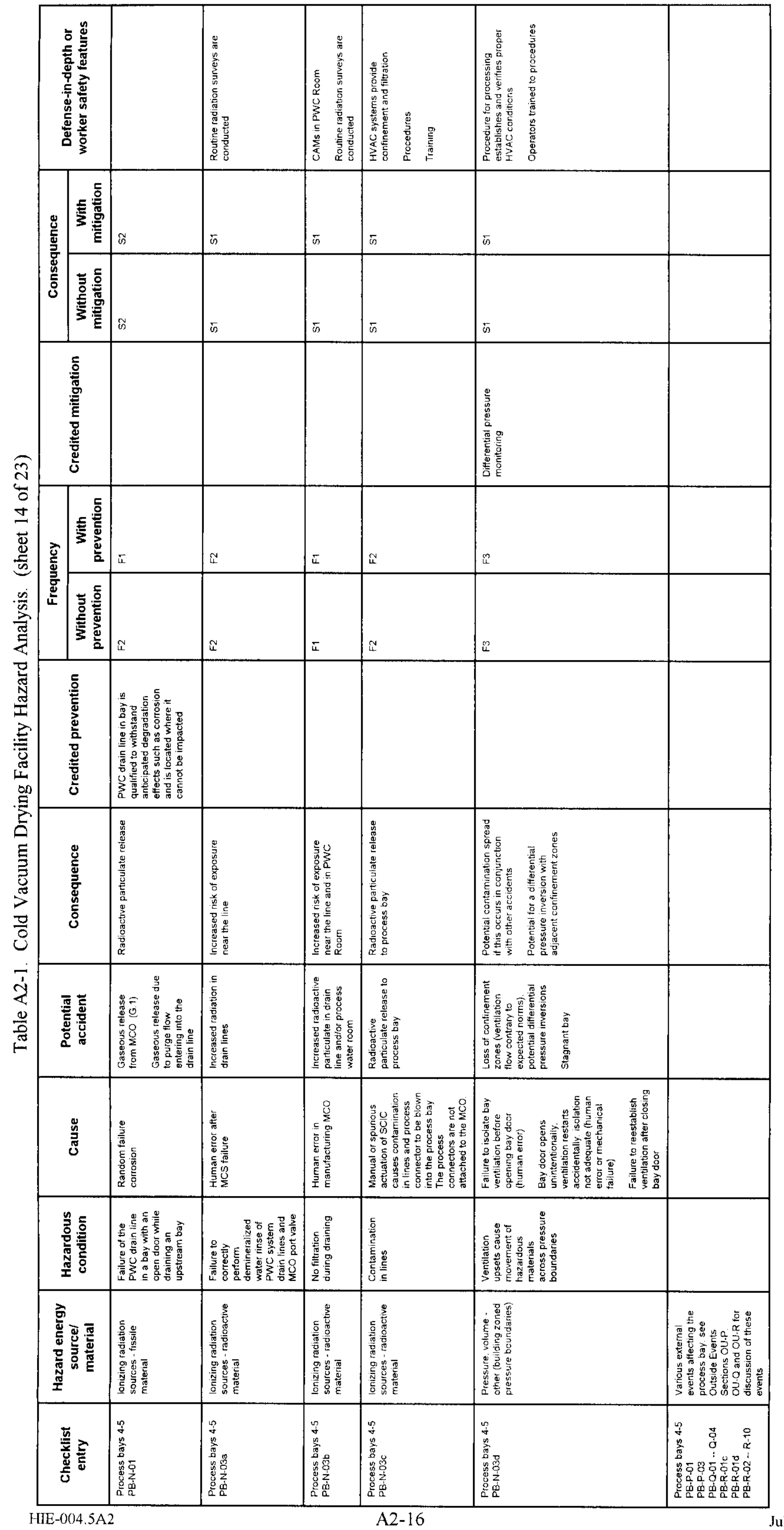


HNF-SD-SNF-HIE-004 REV 5

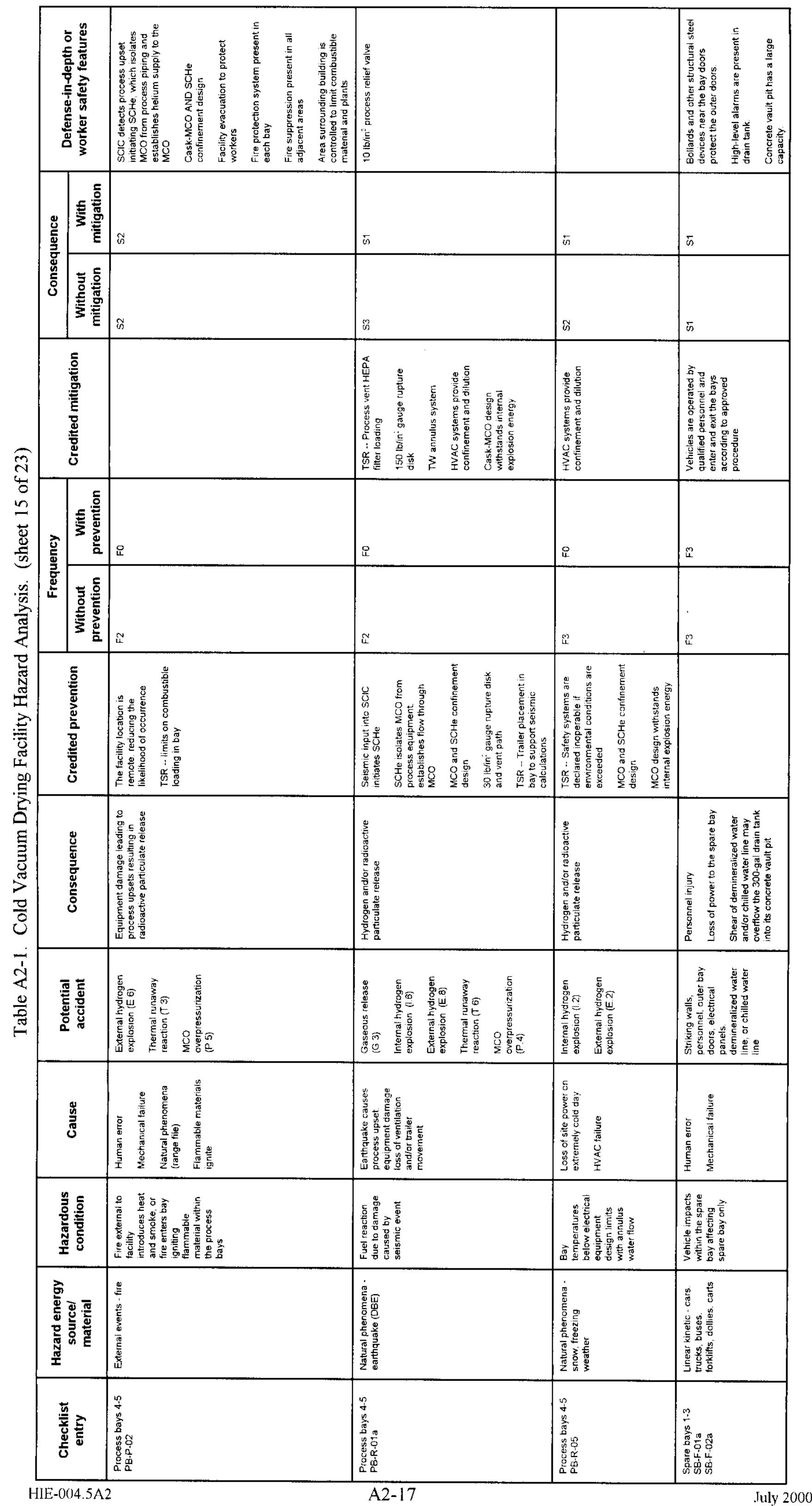


HNF-SD-SNF-HIE-004 REV 5

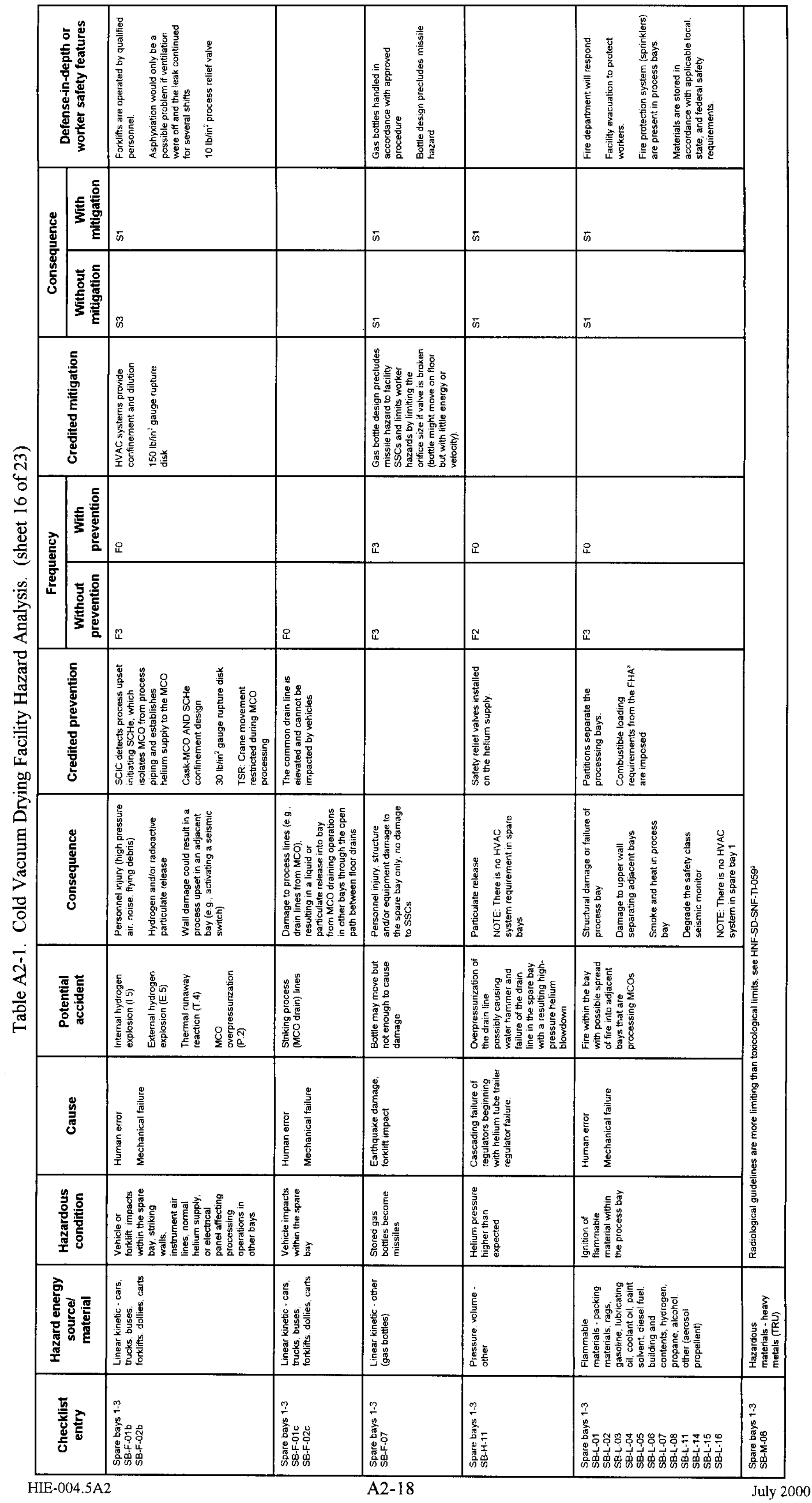


HNF-SD-SNF-HIE-004 REV 5

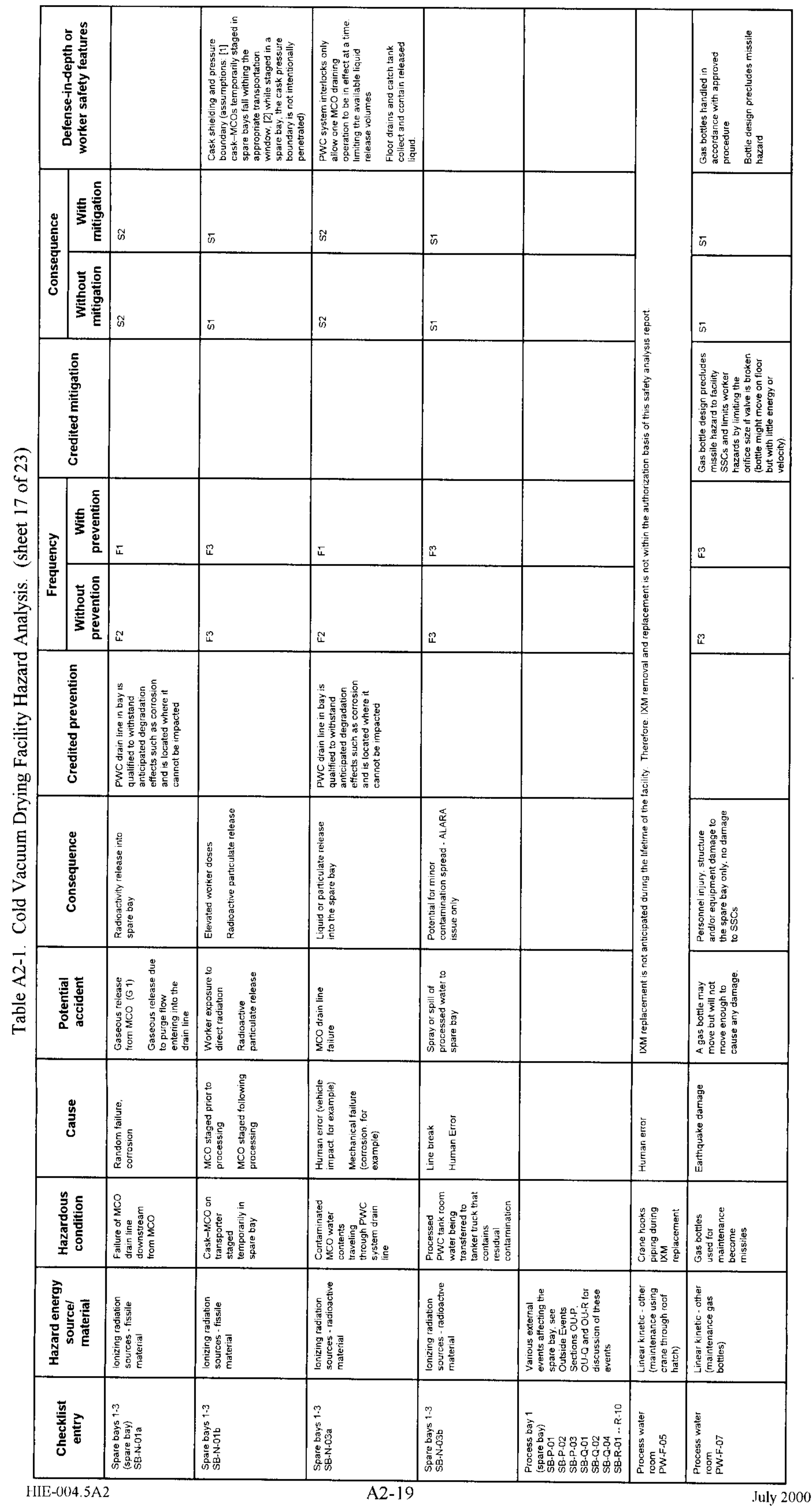


HNF-SD-SNF-HIE-004 REV 5

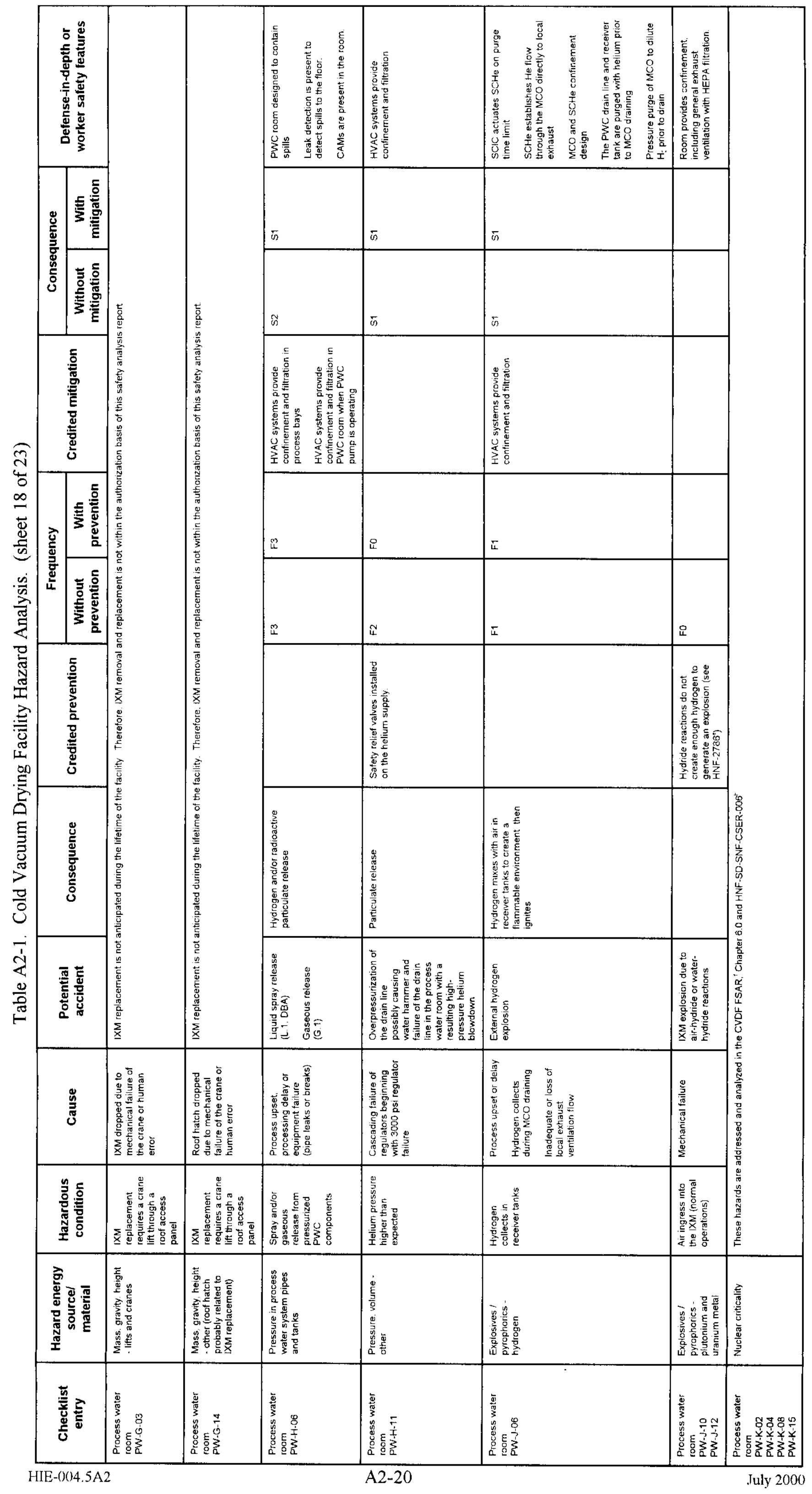


HNF-SD-SNF-HIE-004 REV 5

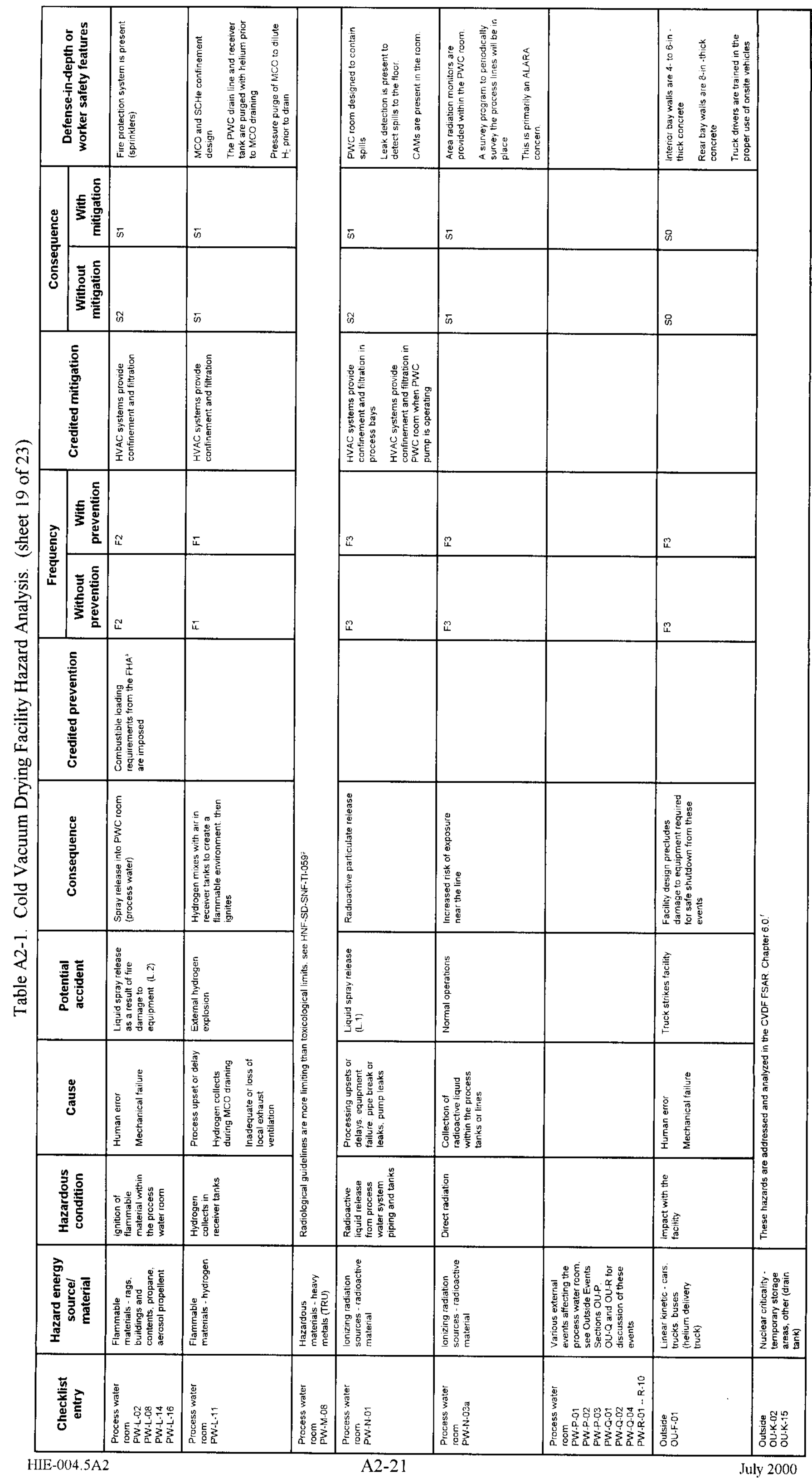


HNF-SD-SNF-HIE-004 REV 5

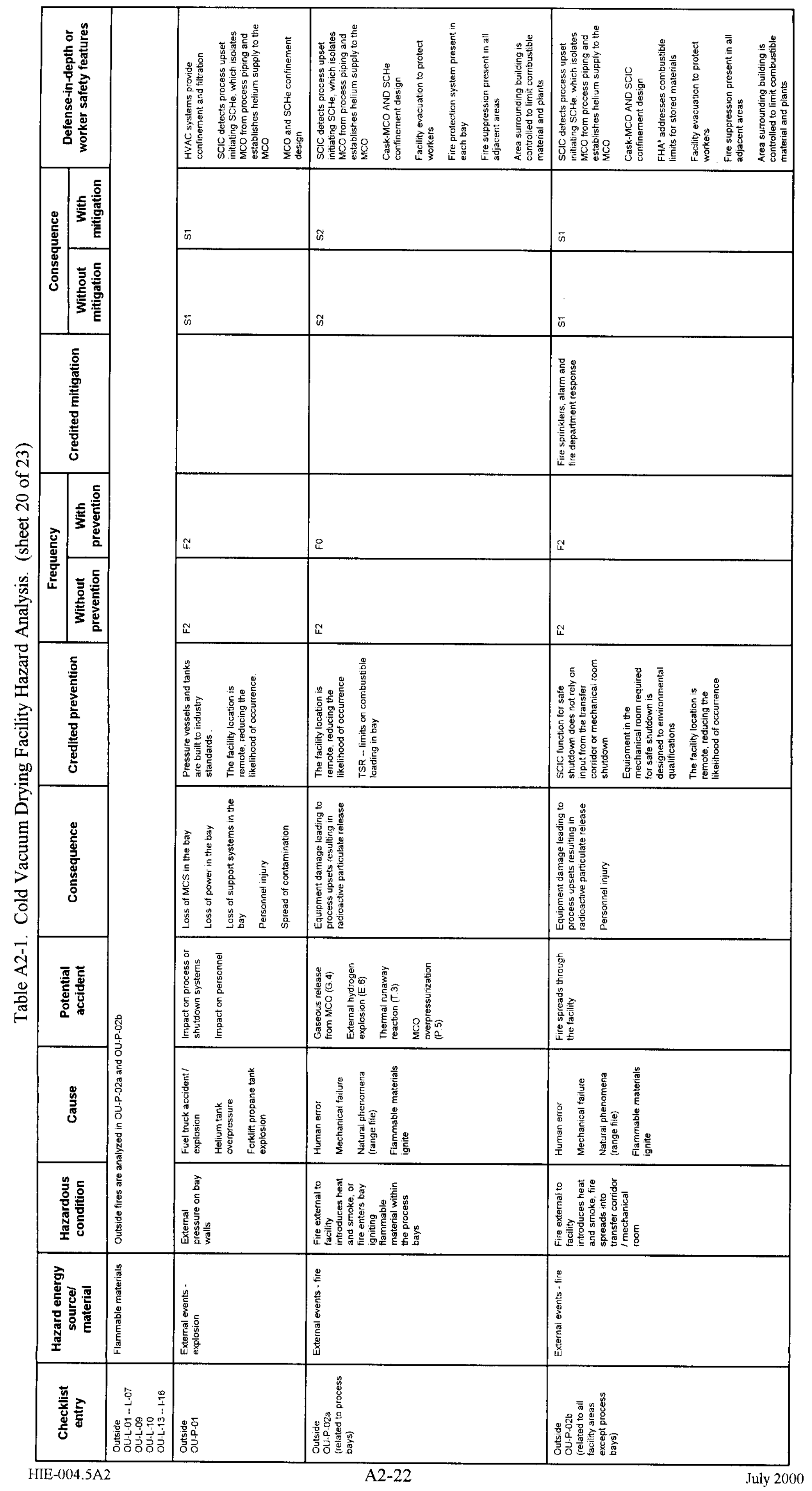


HNF-SD-SNF-HIE-004 REV 5

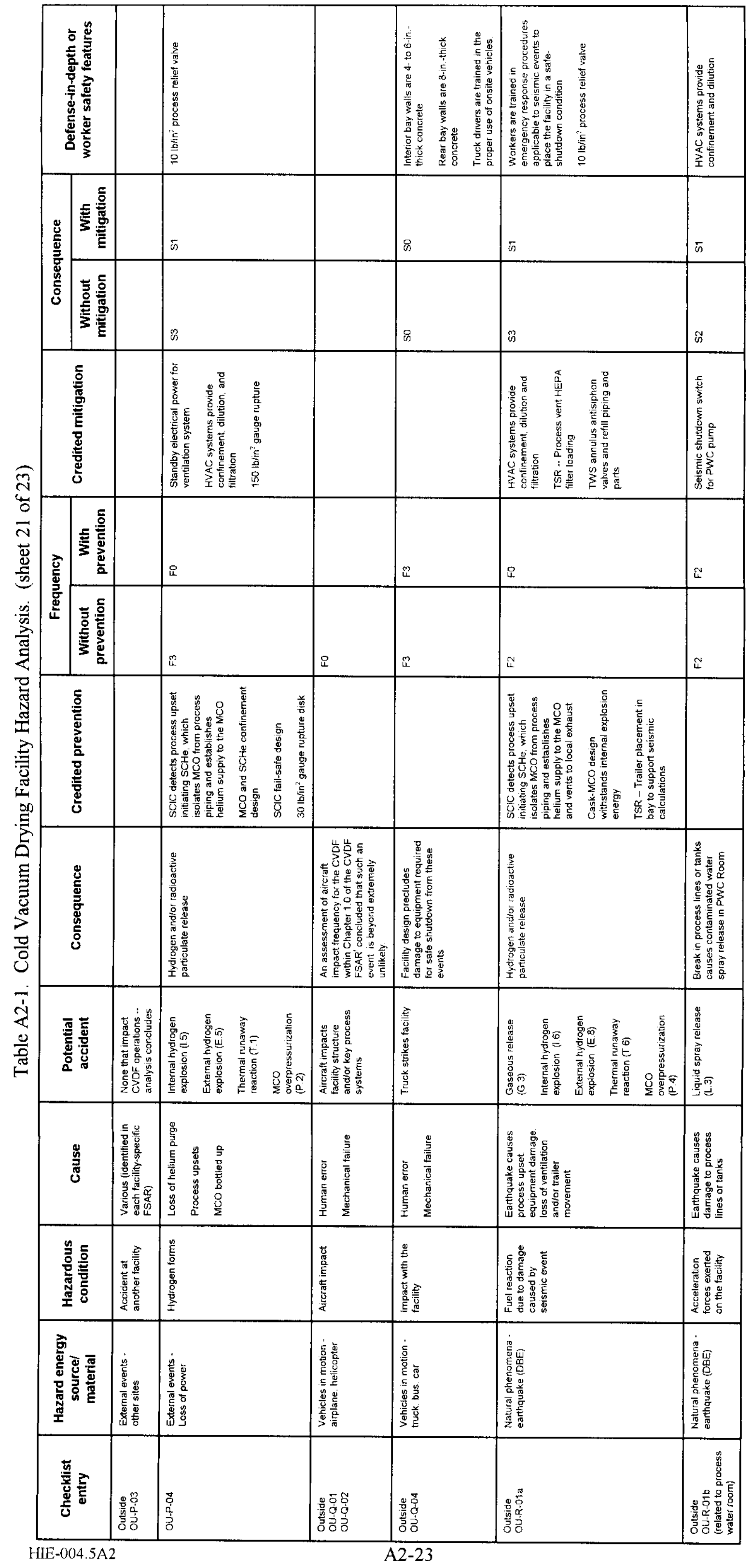


HNF-SD-SNF-HIE-004 REV 5

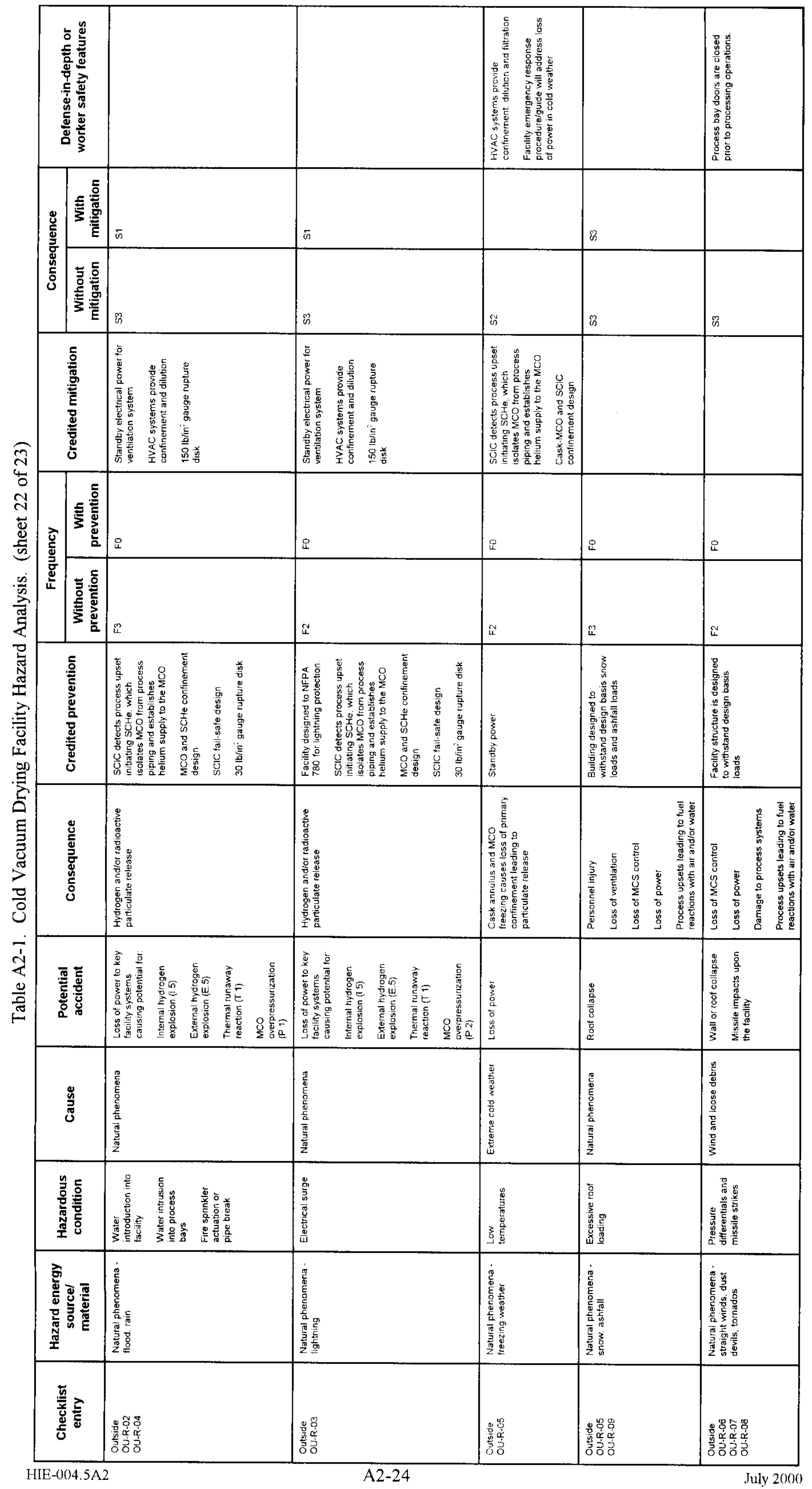


HNF-SD-SNF-HIE-004 REV 5

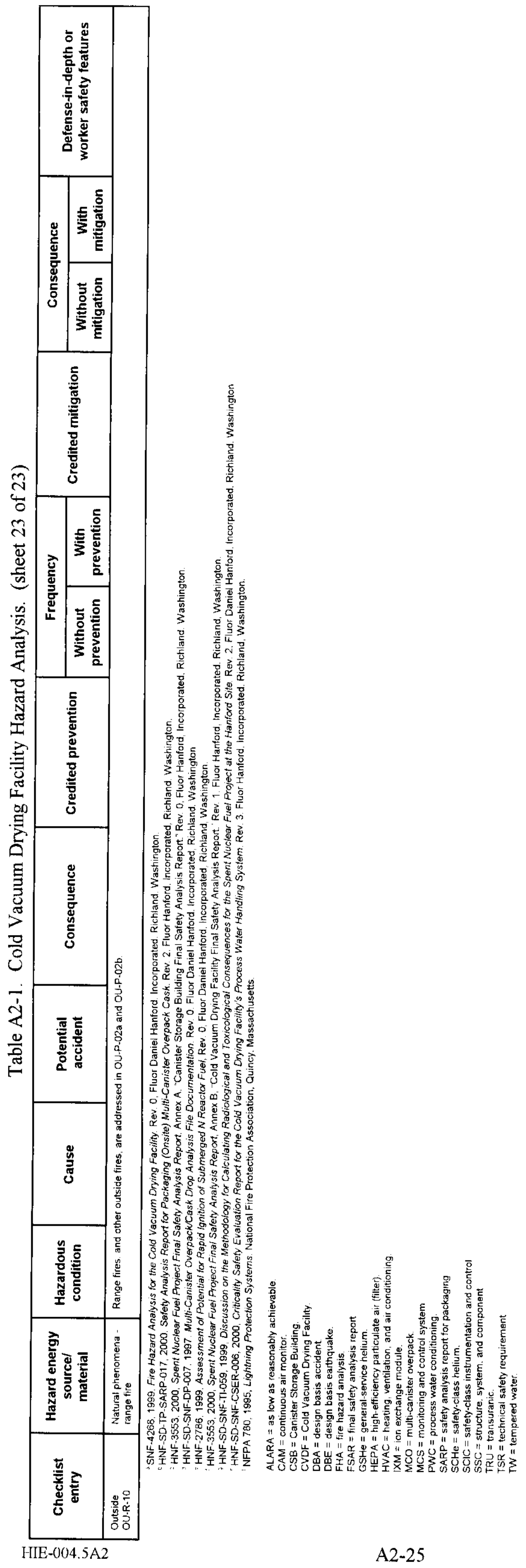


HNF-SD-SNF-HIE-004 REV 5

ATTACHMENT 3

RELEASE CHARACTERISTICS FOR HAZARDOUS CONDITIONS ASSOCIATED WITH OFFSITE (SITE BOUNDARY) AND ONSITE (COLLOCATED WORKER) RECEPTORS 
HNF-SD-SNF-HIE-004 REV 5

This page intentionally left blank. 
HNR-SI)-SNI-HIII:-(10)4 RI:V S

Figure A3-1. Three-hy-Threc I ikelihood and Consequence Ranking Matrix.

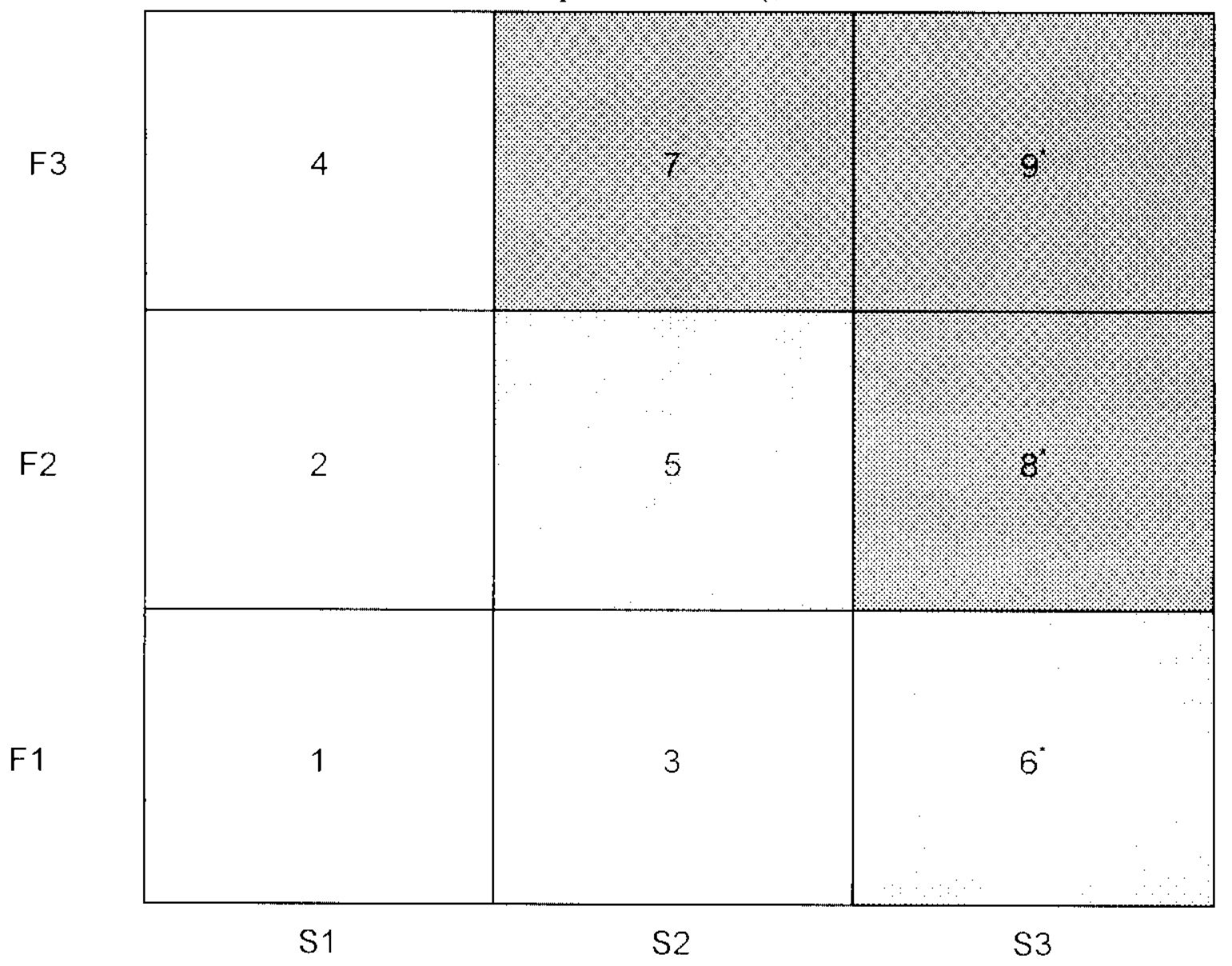

Combinations that identify situations of major concern

Combinations that identify situations of concern

These situations are either prevented or mitigated by satety class features. 


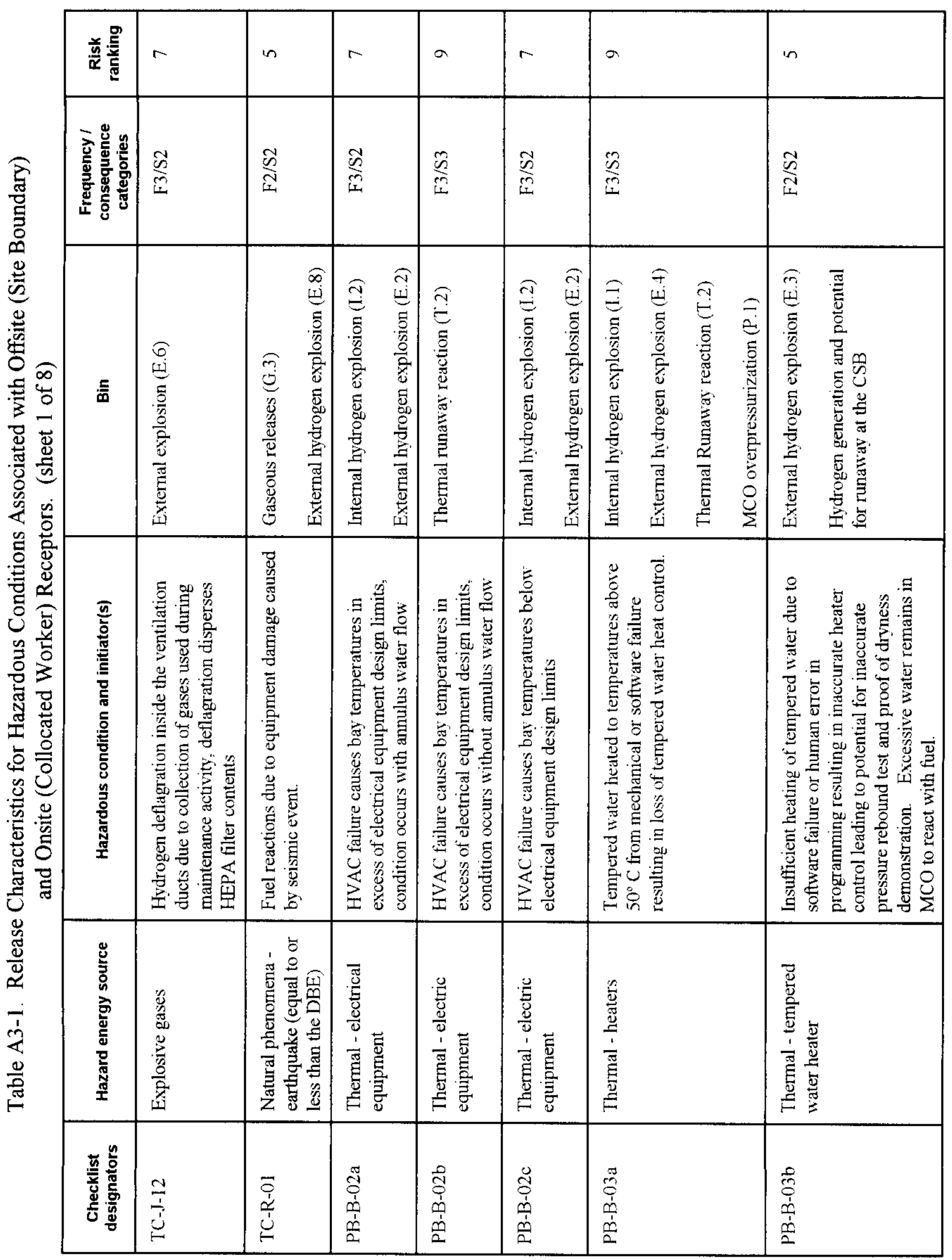




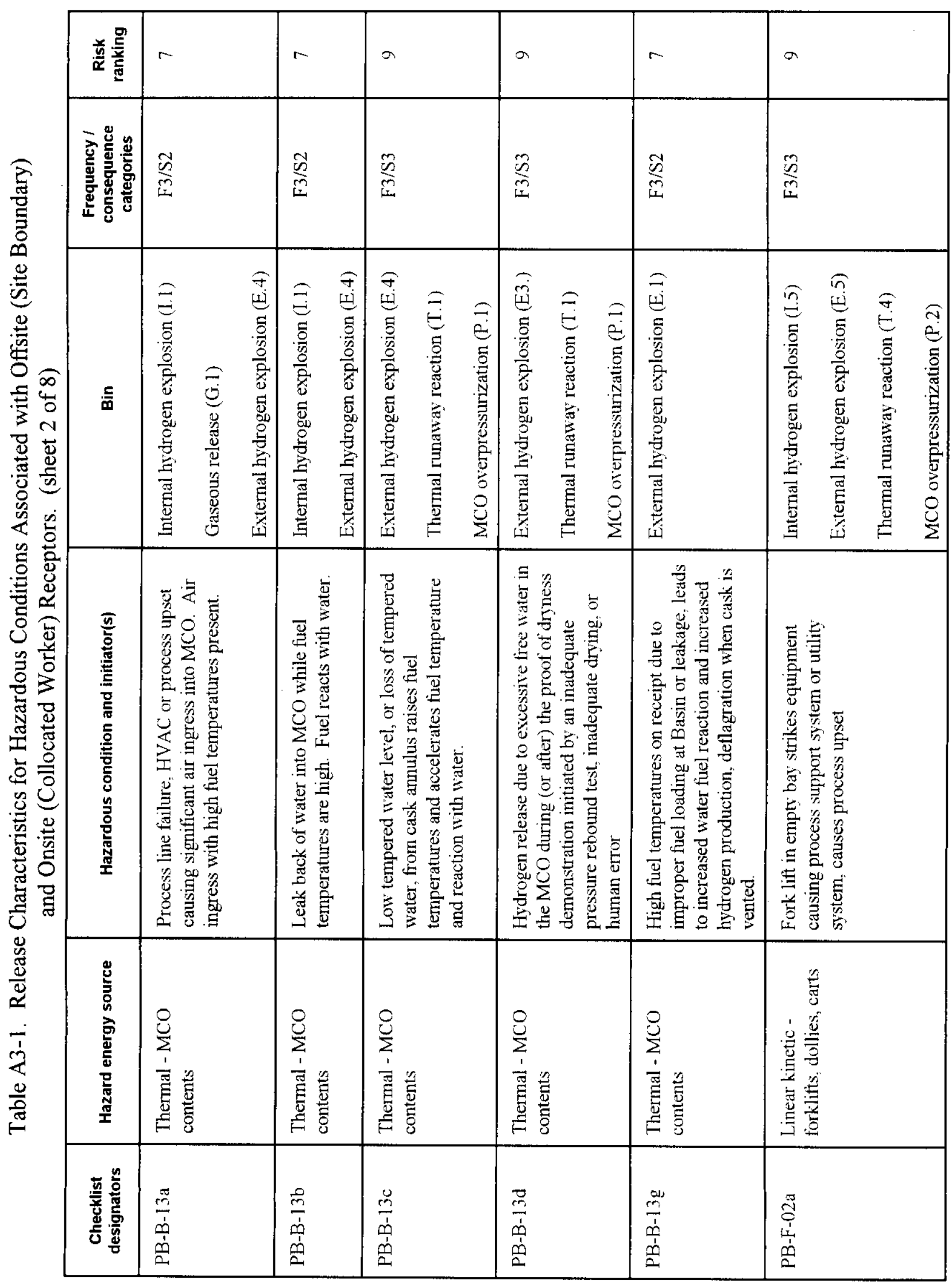


HNF-SD-SNF-HIE-004 REV 5

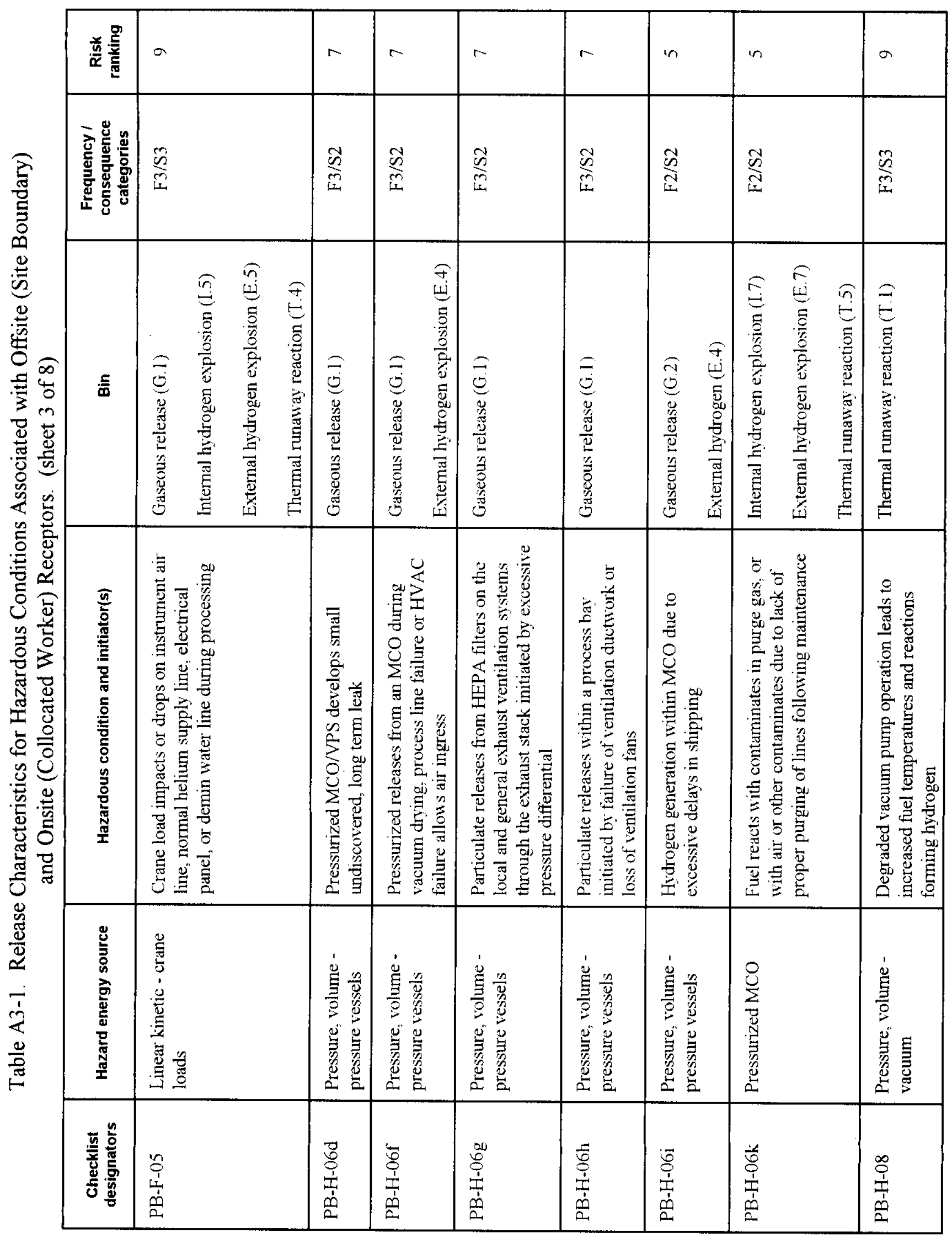


HNF-SD-SNF-HIE-004 REV 5

\begin{tabular}{|c|c|c|c|c|c|c|}
\hline 总噌 & in & $r$ & $r$ & 0 & in & $r$ \\
\hline 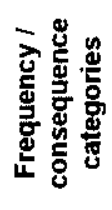 & $\frac{\text { N }}{\text { N }}$ & 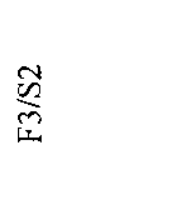 & $\underset{\mathscr{N}}{\tilde{N}}$ & $\underset{\mathscr{L}}{\tilde{Q}}$ & $\underset{\tilde{\omega}}{\tilde{\omega}}$ & $\underset{N}{\infty}$ \\
\hline 亳 & 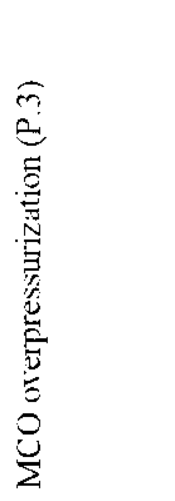 & 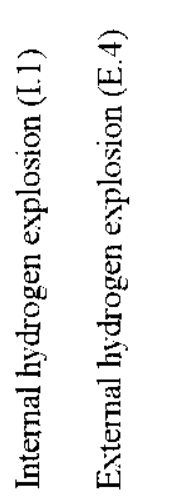 & 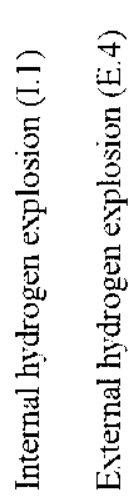 & 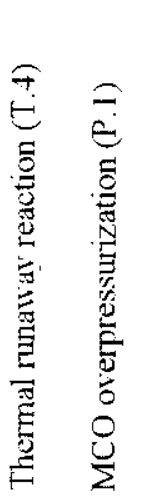 & 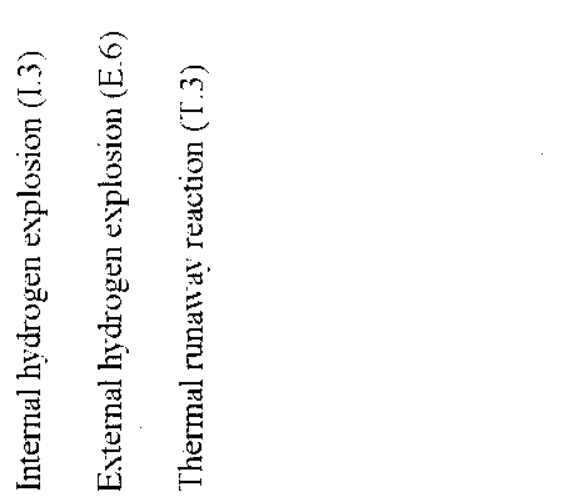 & 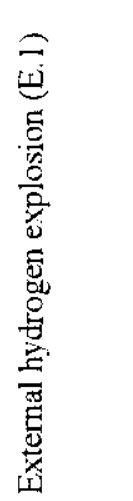 \\
\hline 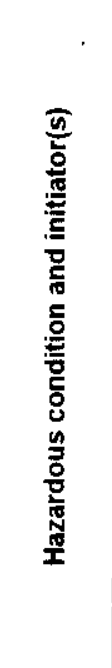 & 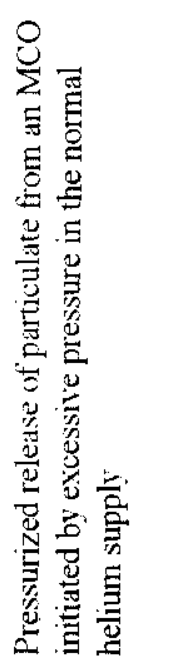 & 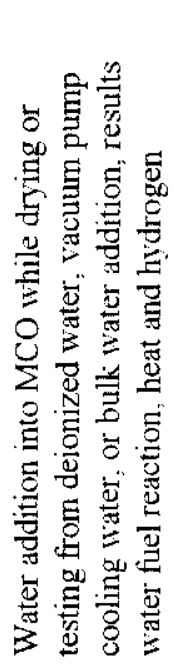 & 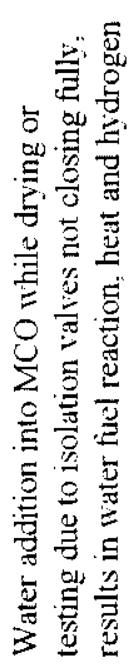 & 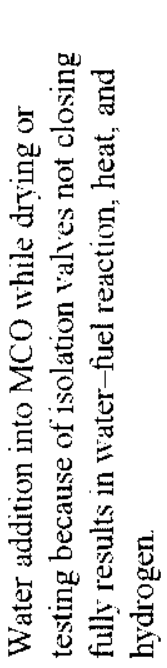 & 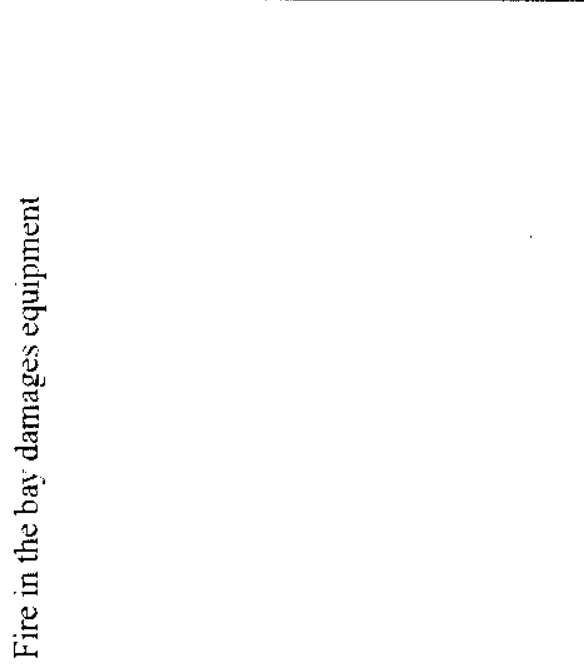 & 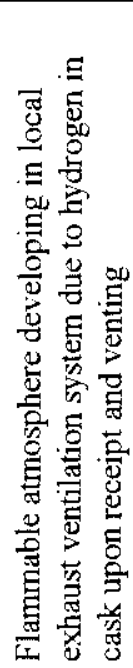 \\
\hline 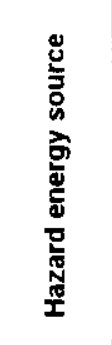 & 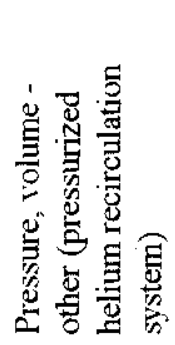 & 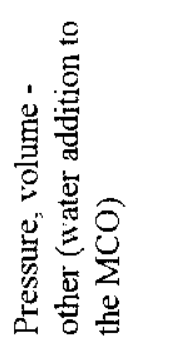 & 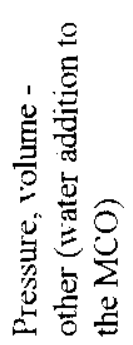 & 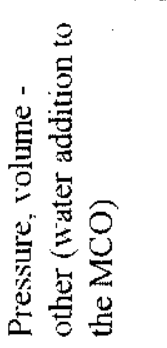 & 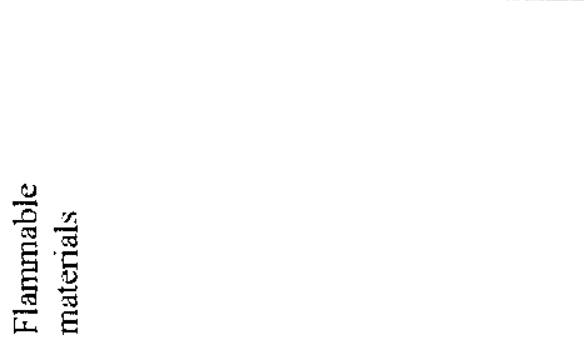 & 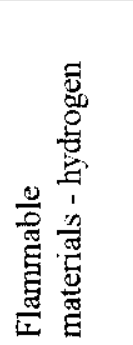 \\
\hline 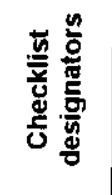 & 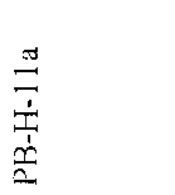 & $\frac{\Xi}{\frac{I}{T}}$ & $\stackrel{\stackrel{\oplus}{\leftrightarrows}}{\frac{1}{\frac{1}{2}}}$ & 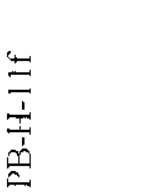 & 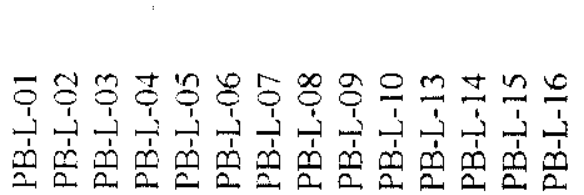 & 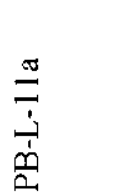 \\
\hline
\end{tabular}




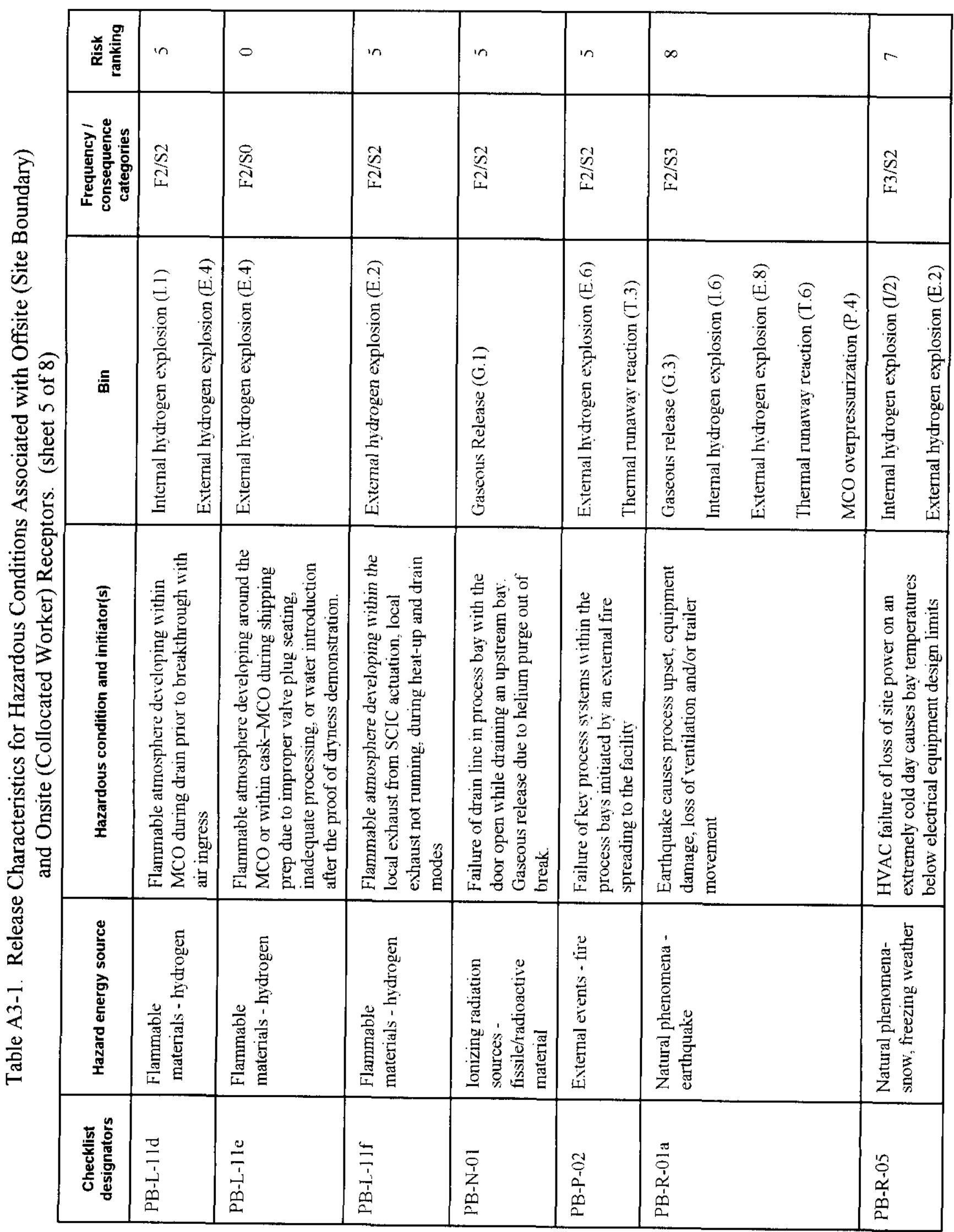




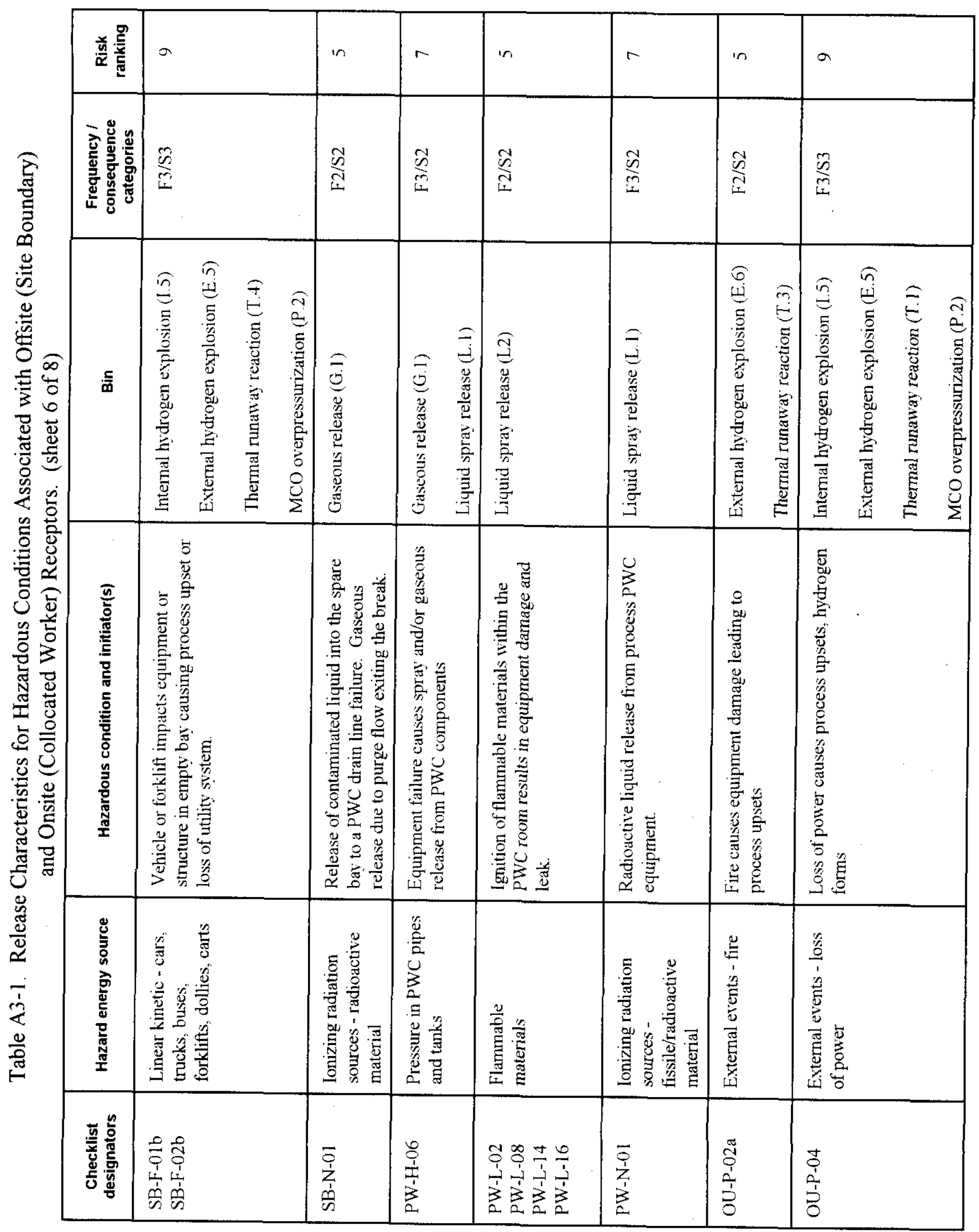


HNF-SD-SNF-HIE-004 REV 5

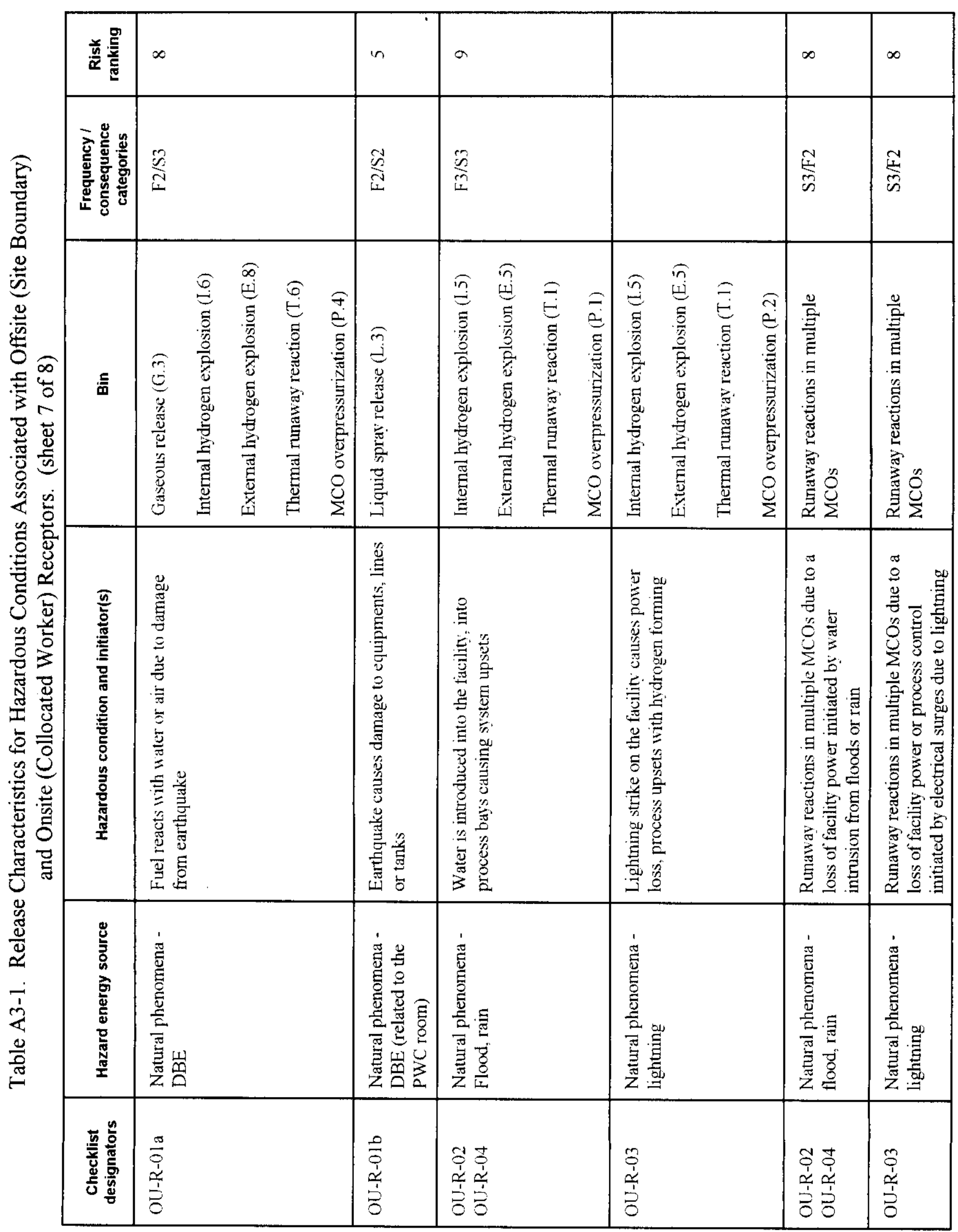


HNF-SD-SNF-HIE-004 REV 5

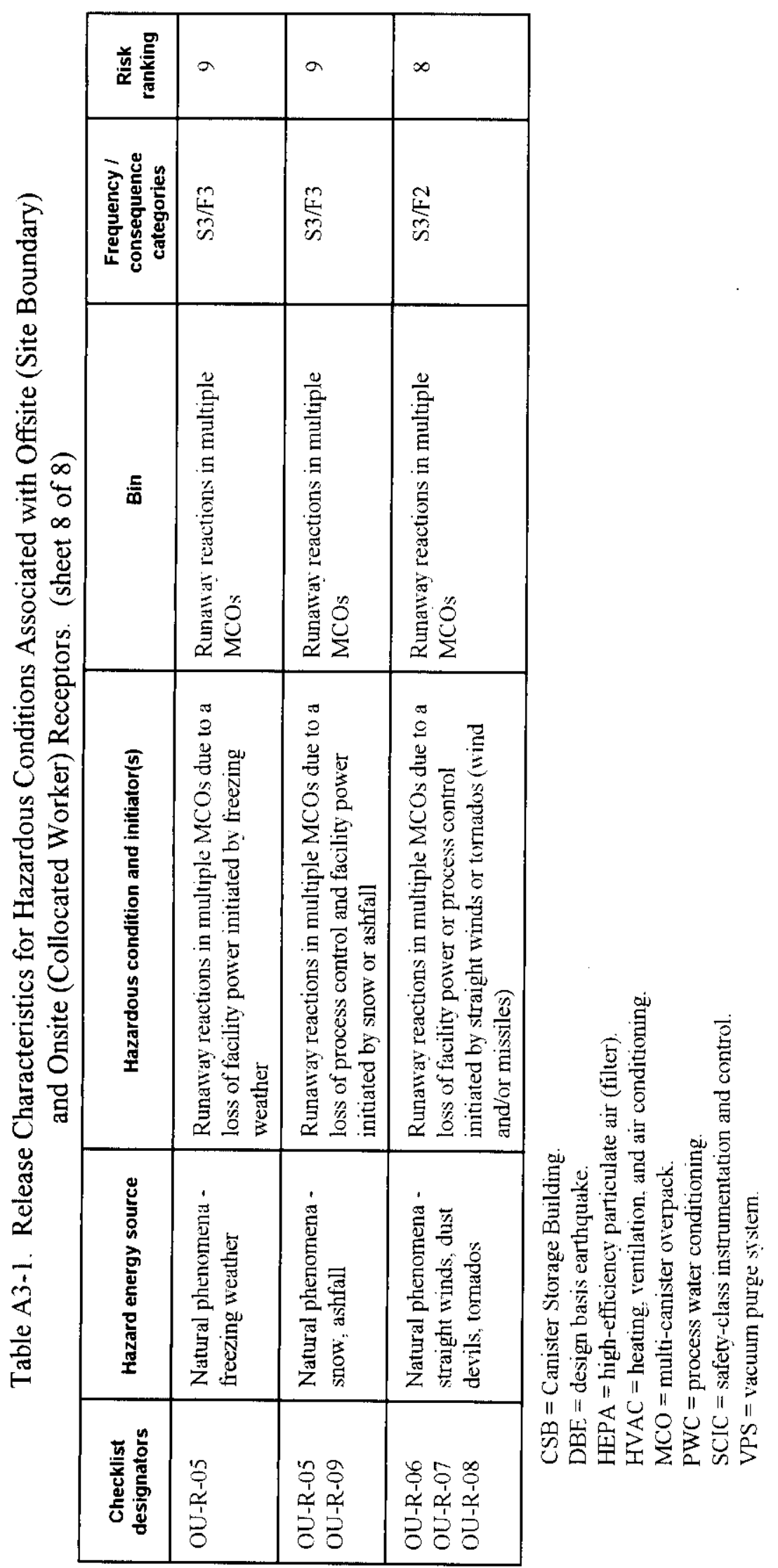




\section{HNF-SD-SNF-HIE-004 REV 5}

This page intentionally left blank. 
HNF-SD-SNF-HIE-004 REV 5

\section{ATTACHMENT 4}

\section{BINNED LISTING OF CANDIDATE ACCIDENTS SORTED BY RISK RANKING}




\section{HNF-SD-SNF-HIE-004 REV 5}

This page intentionally left blank. 


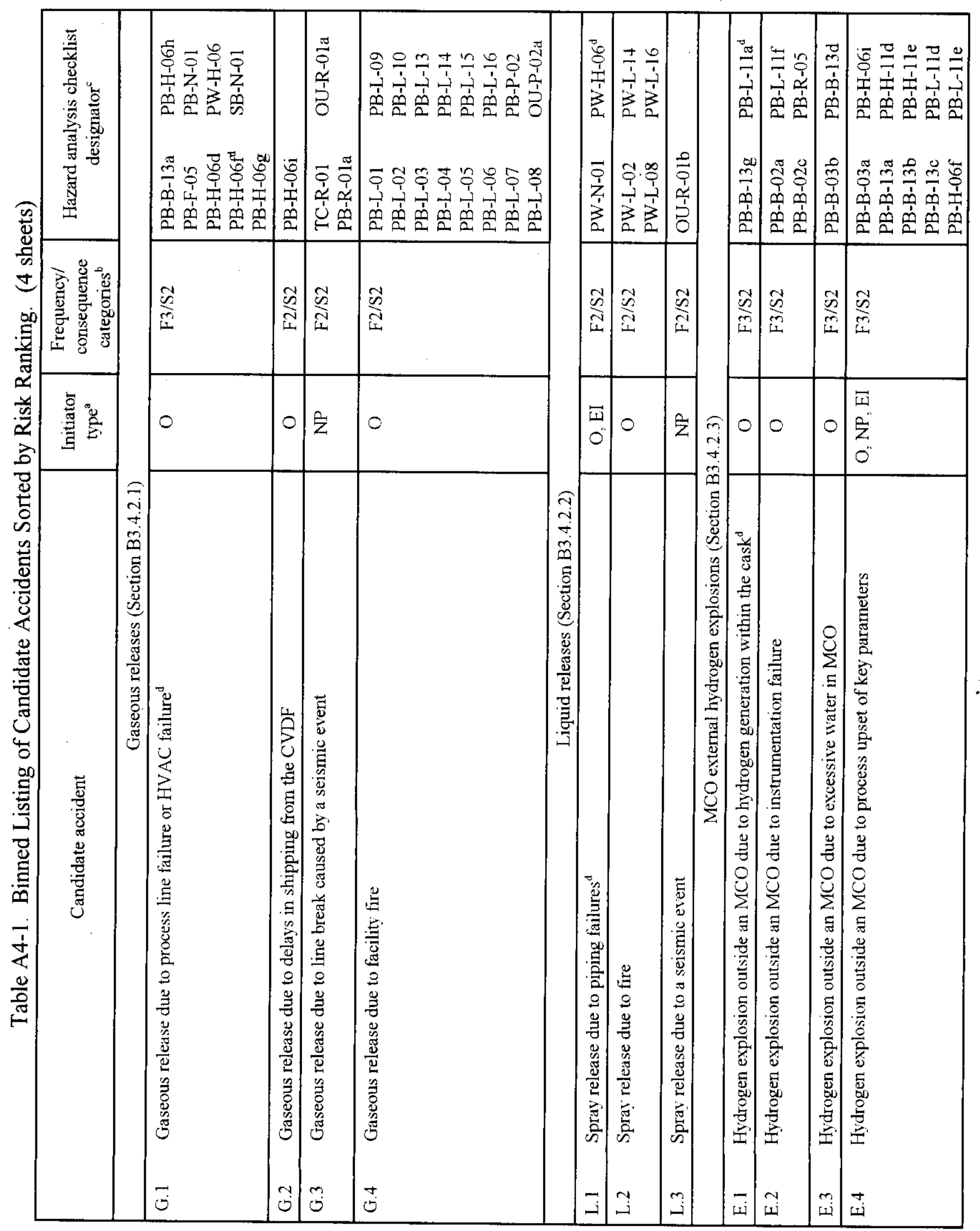




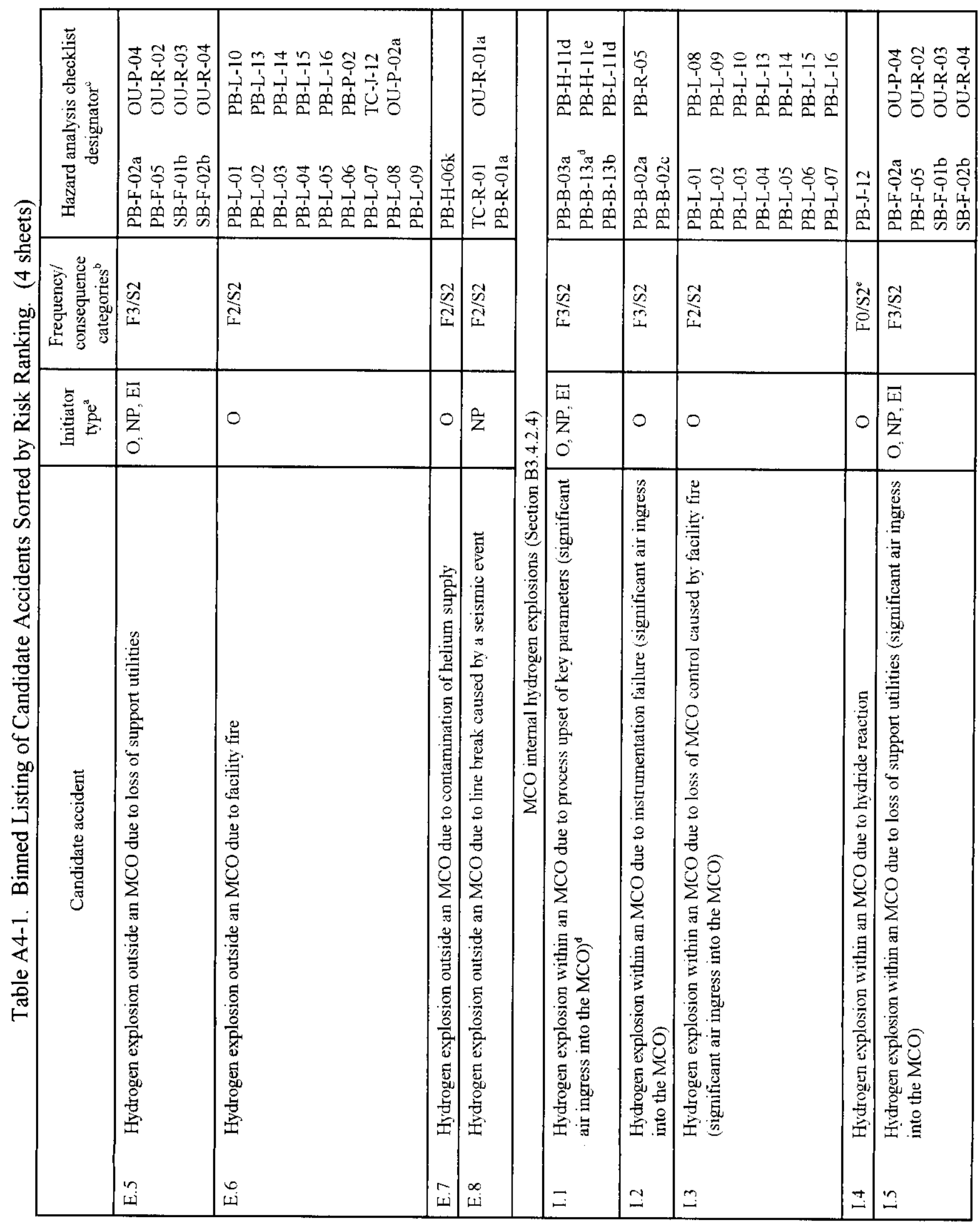




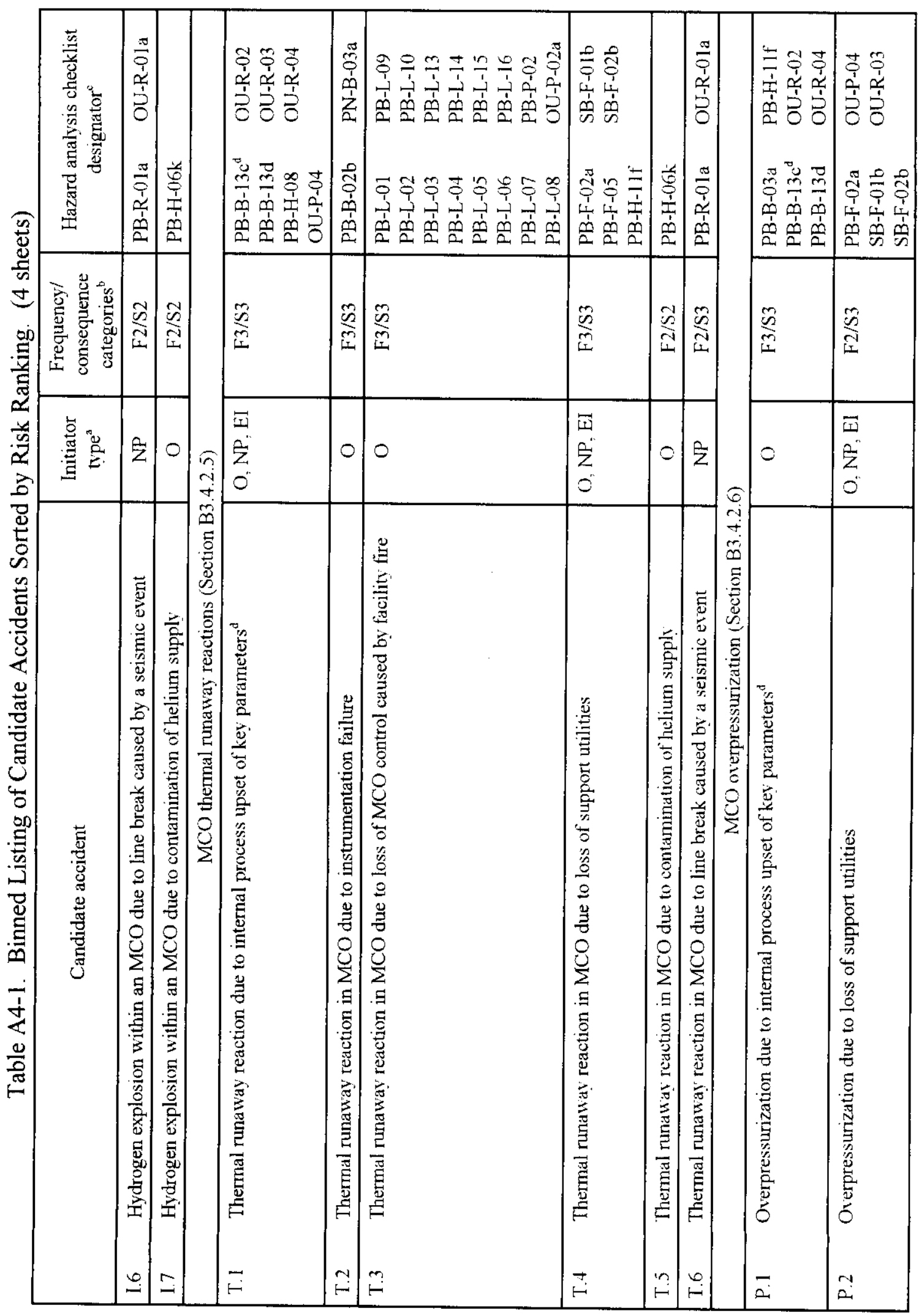




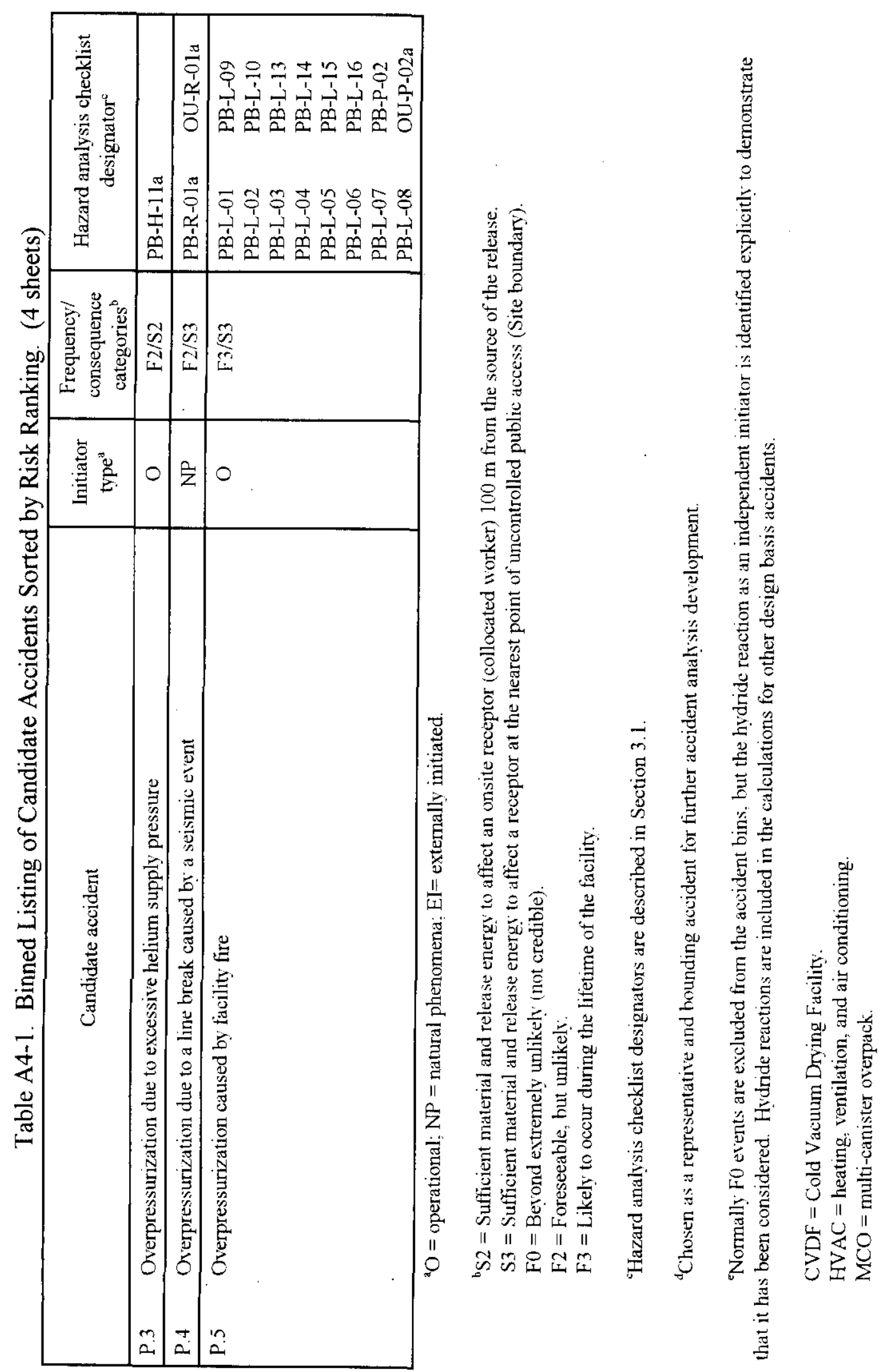




\section{DISTRIBUTION SHEET}

\begin{tabular}{|c|c|c|c|c|c|}
\hline \multirow{2}{*}{$\begin{array}{l}\text { To } \\
\text { Distribution }\end{array}$} & \multirow{2}{*}{\multicolumn{3}{|c|}{$\begin{array}{l}\text { From } \\
\text { Nuclear Safety }\end{array}$}} & \multicolumn{2}{|l|}{ Page 1 of 1} \\
\hline & & & & \multicolumn{2}{|l|}{ Date $7 / 17 / 00$} \\
\hline \multicolumn{4}{|c|}{ Project Title/Work Order } & \multicolumn{2}{|c|}{ EDT No. N/A } \\
\hline \multicolumn{4}{|c|}{$\begin{array}{l}\text { HNF-SD-SNF-HIE-004, Rev. } 5 \\
\text { Cold Vacuum Drying Facility Final Hazard Analysis Report }\end{array}$} & \multicolumn{2}{|c|}{ ECN No. 659308} \\
\hline Name & MSIN & $\begin{array}{l}\text { Text } \\
\text { With All } \\
\text { Attach. }\end{array}$ & Text Only & $\begin{array}{l}\text { Attach./ } \\
\text { Appendix } \\
\text { Only }\end{array}$ & $\begin{array}{c}\text { EDT/ECN } \\
\text { Only }\end{array}$ \\
\hline
\end{tabular}

J. R. Brehm

R3-26 X

R. D. Crowe

R3-26 X

L. J. Garvin

R3-26 $\mathrm{X}$

J. J. Irwin

R3-86 X

D. E. Krahn

R3-26 X

M. A. Medsker

R3-26 X

C. R. Miska

R3-86 $X$

R. K. Ramsgate

$\mathrm{X} 3-78 \quad \mathrm{X}$

R. Whitehurst

R3-86 $X$

IPF 37

H6-08 $X$

SNF Project Files

SNF Nuclear Safety Library

R3-11 X

R3-26 X

